\title{
"Securing" the Nation: Law, Politics, and Organization at the Federal Security Agency, 1939-1953
}

\author{
Mariano-Florentino Cuéllar†
}

American public law is affected by two important dynamics impacting the relationship between citizens and their government: how the executive branch defines national security, and how politicians compete to secure control of the vast public organizations through which governments implement the law. This Article analyzes the intersection of these dynamics by investigating the now-forgotten history of the US Federal Security Agency (FSA) and drawing perspectives from separation of powers, organization theory, and the study of American political development.

In 1939, the Roosevelt White House overcame strong political opposition to centralize vast legal responsibilities within the FSA. Soon after its creation, the agency had acquired responsibility for social security, education, drug regulation, protection of the food supply, civil defense preparedness, supplying employees to war-related industries, facilitating the relocation of Japanese-Americans, antiprostitution enforcement, and biological weapons research. By 1953, the FSA engendered one of the most important American bureaucracies of the twentieth century: the Department of Health, Education, and Welfare. Yet little is known about precisely how or why the White House fought to create the FSA, why the agency pervasively mixed domestic regulatory and national defense functions both before and after World War II, or what its creation wrought for the legal mandates entrusted to the agency.

This Article's analysis reveals how, on the eve of World War II, the White House sought to use the restructuring to achieve greater control over the agency's multiple domains of legal jurisdiction by building oversight capacity in an organizational environment more congenial to the bureaus' functions. It then used that control to publicly promote a broader conception of the "security" issue that held the prospect of more thoroughly protecting domestic programs important to the administration. And by rendering ambiguous the distinction between domestic and international security functions, the administration enlarged support for some of its signature programs at a time when the New Deal legislative coalition was eroding. In effect, the agency's amalgam of legal func-

$\dagger$ Professor and Deane F. Johnson Faculty Scholar, Stanford Law School; Faculty Affiliate, Stanford Center for International Security and Cooperation.

I appreciate helpful conversations with Daniel Carpenter, Michele Dauber, John Ferejohn, George Fisher, Rich Ford, Lawrence Friedman, David Golove, Jill Hasday, Daniel Ho, Don Hornstein, Lewis Kornhauser, David Luban, Eric Muller, Hari Osofsky, Robert Tsai, and Barry Weingast, as well as feedback from workshop participants at Berkeley, Iowa, Oregon, NYU, North Carolina, Southwestern, and Stanford's Center for International Security and Cooperation. David Kennedy provided extremely helpful written comments on an earlier version of this Article. I also benefited greatly from the research assistance of Mindy Jeng, Shivan Saran, Britt Grant, Mrinal Menon, Connor Raso, Brad Hansen, and Jennifer Liu, as well as the staff of the Stanford Law School Library. I am also grateful to the staff at the National Archives in College Park, Maryland, the Franklin D. Roosevelt Presidential Library, and the Harry S. Truman Library. All of these people should be secure in the knowledge that they are not responsible for any errors or omissions. This is dedicated to Mateo, Ria, and Lucy. 
tions epitomized the administration's ambitious conception of "security," which became sufficiently elastic to encompass legal responsibilities now routinely segregated into domains involving social services, economic security, health regulation, and geostrategic national defense.

These dynamics illustrate limitations in prevailing theories of law and organization emphasizing deliberately engineered bureaucratic failure or purely symbolic position-taking. They also showcase the historical connection between the design of public agencies, separation of powers, and the ambiguities inherent in the definition of "security" as a category of government responsibility. The recent spike of interest in homeland security is furnishing similar opportunities to reshape the domestic regulatory state.

\section{TABLE OF CONTENTS}

Introduction: Two Security Problems .................................................589

I. The Evolution of the FSA ……...............................................59

A. The Case, Some Puzzles, and Its Context............................600

B. Creation of the FSA: "To Strengthen the Arms of Democracy".

C. Overview of Evolution and Growth

D. Broadening the Scope of "Security"

II. Updating Theories of the Political Design of Legal Mandates.. 637

A. Building Blocks for a Theory of Law and Organization:

Strategic Action, Divided Control, and Crisis ..................638

1. Centrality of strategic action. ..........................................642

2. Divided control and prescriptive ambiguity...................645

B. Theoretical Refinements: Capacity-building,

Coalition Expansion, and Endogenous Crisis

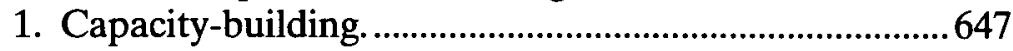

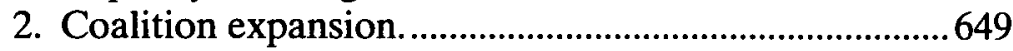

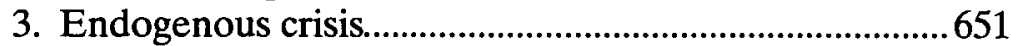

4. Shaping law by altering organizational evolution.........653

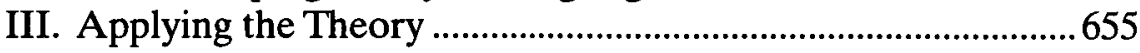

A. Augmenting Capacity for Presidential Control ..................656

1. Motivations: more control, and more to control ..........656

2. Adding a layer of political staff ........................................660

3. Changing the organizational environment affecting presidential goals

4. Using a broad mandate as cover for sensitive projects

5. Why Congress allowed greater presidential control when it had fought White House growth 
B. Enhancing Political Coalitions

1. Shaping public perceptions of the meaning of "security"

2. Enlarging legislative coalitions by ambiguating functions

3. The connection between rebranding and bureaucratic reorganization.

IV. Implications and Extensions.

A. Changing Capacity for Agency-driven

Policy Innovation

B. Expanded Pressure for Legislative Reorganization 699

C. An Organizational Gloss on Separation of Powers. 701

D. The Complexities of Security. 706

\section{INTRODUCTION: TWO SECURITY PROBLEMS}

[T]here is nothing more difficult to carry out, nor more doubtful of success, nor more dangerous to handle, than to initiate a new order of things. For the reformer has enemies in all those who profit by the old order, and only lukewarm defenders in all those who would profit from the new order, this lukewarmness arising partly from fear of their adversaries, who have the laws in their favour; and partly from the incredulity of mankind, who do not ... believe in anything new until they have had actual experience of it.

$$
\text { -Niccolo Machiavelli }{ }^{1}
$$

In a modern state the actual ruler is necessarily and unavoidably the bureaucracy, since power is exercised neither through parliamentary speeches nor monarchical enunciations but through the routines of administration.

$$
- \text { Max Weber }^{2}
$$

Consider the following irony. During the 1930s the administration of Franklin Delano Roosevelt spurred major growth in the federal state

\footnotetext{
Niccolo Machiavelli, The Prince 24 (Oxford 1957) (Luigi Ricci, trans).

2 Max Weber, 3 Economy and Society: An Outline of Interpretive Sociology 1393 (Bedminster 1968) (Guenther Roth and Claus Wittich, eds, and Ephraim Fischhoff, et al, trans). Whether and when a distinction can be drawn between "the bureaucracy" and presidential "enunciations" is, of course, a more complicated question in light of the Roosevelt administration's decisions about the Federal Security Agency.
} 
by stressing government's role as guarantor of the nation's security. With security as a lodestar, administration priorities led to now-familiar statutory changes catalyzing financial regulation, retirement and unemployment benefits, food safety policies, and energy rules. As the New Deal matured, security-related rationales taking subtly distinct formsemphasizing international, geostrategic concerns-also bolstered the case for expansive federal power and even blended with the more expansive domestic risk-reduction ideas in the period before World War II. In 1939, for example, the administration wove together multiple strands of its security trope while using a sliver of legal authority for executive reorganization to forge a colossal new Federal Security Agency (FSA). It then proceeded to justify the executive branch's new legal architecture by arguing that the ability to face international threats depended on the strengthened domestic capacity provided by the FSA to implement the law effectively in domains such as health and education. ${ }^{4}$

But for all its success reconstructing the national agenda around an expansive conception of security, by the late 1930s the administration was losing capacity to secure its own control of the outsized federal state it had created. In Humphrey's Executor v United States, the Supreme Court refused to let the president fire a Federal Trade Commission (FTC) official whose term had been fixed by Congress, ${ }^{6}$ thereby eviscerating presidential power over an ever-multiplying empire of independent commissions and opening the door to even greater congressionally imposed limits on presidential power. In the process, the Court rejected the view that proper presidential supervision of the executive branch under Article II depended on the power to fire senior officials, an idea central to the Court's conception of executive power articulated in Myers $v$ United States ${ }^{7}$ decided just a few years earlier. ${ }^{8}$ Meanwhile, Congress was increasingly designing the structure of agencies like the Social Security Board (SSB) to disrupt presidential

3 See David Kennedy, Freedom from Fear: The American People in Depression and War, 1929-1945 257 (Oxford 1999) (explaining that Roosevelt's idea was to provide "present relief, future stability, and permanent security").

4 See Franklin D. Roosevelt, Message of the President: Reorganization Plan No. 1 of 1939 (Apr 25, 1939), reprinted in 5 USC App (stating that the purpose of the FSA is to "promote social and economic security, educational opportunity and the health of the citizens of the Nation").

5295 US $602(1935)$.

6 Id at 629-30.

7272 US 52 (1926).

8 Id at $175-77$ (holding that the president can fire the postmaster general at his discretion even though the Congress passed a statute requiring the president to get the consent of the Senate to fire him). 
control,' blocking White House staff expansion, and refusing to grant reorganization authority, which the Roosevelt administration considered essential to securing control of a rapidly growing federal state. ${ }^{10}$

This Article illuminates the fertile intersection of both "security" problems: the control politicians seek to secure over agencies with expansive legal powers, and the security that modern nation-states promise citizens when justifying why public bureaucracies must be given such powers in the first place. Time and again, whether the subject is the Roosevelt-era FSA or the Bush-era Department of Homeland Security (DHS), these two security problems turn out to be deeply enmeshed within the web of federal regulatory power. Bureaucratic control helps executive branch officials and their lawyers promote a particular definition of security through legal interpretations, public communications, legislative initiatives, and discretionary decisions. Security concerns, meanwhile, shore up public justifications for organizational changes affecting political control over law's implementation. By understanding how these two problems intersect, we can grasp underappreciated tensions coursing through public law-such as how agencies shape public perceptions about the laws they implement, how the definition of "security" has changed as the architecture of the executive branch has evolved, and how to understand the consequences of forging the modern-day DHS.

Linking these themes is an extended case study on the legal history of the FSA. Placing this agency in the larger context of its bureaucratic brethren, this Article shows how politicians exploit reorganizations, particularly during or in anticipation of national security emergencies, to reshape agencies' legal mandates by controlling their bureaucratic power." It shows how changes in the organization of political officials, civil servants, and government bureaus can enhance presidential control. Simultaneously, such changes can repackage regulatory activities in relation to the concept of national security, bolstering the political coalitions supporting those functions. These dynamics have typically escaped scholarly attention among academics specializing in bureaucra-

9 See Martha Derthick, Agency under Stress: The Social Security Administration in American Government 20-21 (Brookings 1990) ("Congress chose to make the [new SSB] independent of any executive department.").

10 See Harvey C. Mansfield, Federal Executive Reorganization: Thirty Years of Experience, 29 Pub Admin Rev 332, 337 (1969) (describing Roosevelt's frustration); Kenneth S. Davis, FDR: Into the Storm, 1937-1940: A History 19 (Random House 1993) (noting that, after Roosevelt's election to a second term, "the subject uppermost in his mind on this third morning of the new year was ...governmental reorganization").

11 The term "legal mandate," used interchangeably with "legal responsibility," refers to legal rules or standards implemented by an agency (for example, through particular regulations, enforcement strategies, or allocation of responsibilities among bureaucracies). 
cy, whose work in recent years tends to focus on elucidating how politicians reorganize government to satisfy a preexisting public demand or to deliberately sabotage agency activities. ${ }^{2}$ Nor have scholars in the developing field of national security law fully investigated questions about the scope of national security rather than the surveillance, detention, emergency, or foreign affairs powers deployed in the name of security.

Although the FSA has been all but forgotten, even cursory scrutiny reveals it to be among the more important bureaucracies created in twentieth-century America. The FSA was the gangly and occasionally brash adolescent-equal parts wartime soldier and audacious dreamer - that matured into the federal government's sprawling health, welfare, and civil defense apparatus. The agency was born amid a tangle of administrative changes enshrined in statutes as the New Deal morphed into the American response to World War II. Its litany of statutory responsibilities at once confirms what has today become a familiar picture of federal functions, encompassing medical research, civil defense, social security, federal education assistance, weapons development, and food and drug regulation. But the list also scrambles modern sensibilities about the line dividing conventional national security functions from domestic regulatory activities.

President Roosevelt began blurring that line nearly two and a half years before the Pearl Harbor attacks. ${ }^{13}$ On April 25, 1939, he delivered a long-expected announcement about his plans to reshape the

12 For prominent work focusing on the near-inevitable production of ineffectiveness and failure through changes in formal organization, see Terry M. Moe, Politics and the Theory of Organization, $7 \mathrm{~J} \mathrm{~L}$, Econ, \& Org 106, 126 (1991). For an example of scholarship focusing on the considerable extent to which legislative and bureaucratic changes may be explained by focusing on position-taking benefits, see David Mayhew, Congress: The Electoral Connection 147-51 (Yale 1974). For work emphasizing the spontaneous development of routines and the diffusion of ideas as an explanation for bureaucratic organization, see David Strang and John W. Meyer, Institutional Conditions for Diffusion, 22 Theory \& Socy 487, 506 (1993). See also Part II.

13 The most extensive existing scholarly commentary on the FSA appears to be in Rufus Miles's The Department of Health, Education, and Welfare, which is about five pages long and contains virtually no analysis of White House motives for the reorganization, bureaus' budgets, or news coverage of the department. See Rufus Miles, The Department of Health, Education, and Welfare 18-24 (Praeger 1974). Perhaps influenced by the putative scope of his project's focus on the Department of Health, Education, and Welfare (HEW) as opposed to its predecessor agency, Miles stresses the expectations of those who participated in the FSA's elevation to cabinet status, rather than those who forged the FSA. See, for example, id at 3 ("When HEW first came into being as a Cabinet department in 1953 , it did not occur to any of its many midwives that it would grow so rapidly."). A leading history of the Public Health Service (PHS) dismisses the significance of the FSA by citing Miles, and then proceeds to explain the important changes the PHS experienced during the war period without considering how the bureau would have fared if it had remained at the Department of the Treasury. See Fitzhugh Mullan, Plagues and Politics: The Story of the United States Public Health Service 111-16 (Basic 1989). Mullan also furnishes reason to question his contention about the relative insignificance of the merger by noting that it changed the PHS's relationship to the SSB. See id at 110 . 
architecture of the executive branch. ${ }^{14}$ The change in architecture had been on the president's agenda for over twenty-four months, but the specific changes he had in mind had only become possible after Congress grudgingly gave the president limited reorganization powers three weeks earlier. Thwarted in an ambitious effort to create a cabinetlevel Department of Public Welfare the previous year, the Roosevelt White House nonetheless announced that it would use its more modest reorganization power to unify a half-dozen bureaus involved in health regulation, economic security, and education in a new subcabinet, the Federal Security Agency. From then on the FSA expanded steadily. By 1943, the FSA's bureaus included the Public Health Service (PHS), the Social Security Board, the Office of Education, the Food and Drug Administration (FDA), the Office of Community War Services, the War Research Service (WRS), and nearly a dozen other organizations. ${ }^{15}$ By 1953, the agency became the Department of Health, Education, and Welfare (HEW). And by the 1970s, HEW's budget accounted for nearly half of federal nondefense expenditures, dwarfing the national budget of every country except Soviet Russia."

To observers situated in the early twenty-first century, however, the name of the Federal Security Agency foreshadows DHS more than it does a welfare agency. Legal history readily demonstrates how the meaning of "security" is versatile. Until the current economic downturn, the term elicited concepts of economic risk reduction more easily in the 1930s than in recent years. As will become clear, however, some aspects of the FSA's work nonetheless fit readily with more modern applications of the term, presaging its subsequent evolution. It was the FSA that facilitated the resettlement of Japanese-Americans. ${ }^{18}$ It was the FSA that laundered White House funds and funneled them into secret biological weapons research even when the United States had signed a treaty outlawing such activity. ${ }^{19}$ FSA officials presided over the rapid growth of a national system to train workers for war-related occupa-

14 See Roosevelt, Message of the President (cited in note 5).

15 See Miles, Department of Health, Education and Welfare at 18-24 (cited in note 13).

16 See id.

17 See Part I on the origins, and components, of the FSA. For the text of the president's announcement, see Roosevelt, Message of the President (cited in note 5) (explaining that the total overhead of the agencies involved in the reorganization was $\$ 235$ million). See also Budget of the United States, 1980 (OMB 1979); Miles, Department of Health, Education and Welfare at 3 (cited in note 13) (discussing HEW's budget in relation to that of other countries).

18 See Dorothy Swaine Thomas, Some Social Aspects of Japanese-American Demography, 94 Proceedings Am Phil Socy 459, 474 (1950); Comment, Alien Enemies and Japanese-Americans, 51 Yale L J 1316, 1324 (1942).

19 See Letter from George W. Merck, Director, War Research Service to Lt Col Chester W. Goble, State Director, Selective Service System (May 1, 1944), available at National Archives, War Research Service Files, Entry 5A, Box 12. 
tions. They set up recordkeeping systems to assist a national military draft. The agency's inspectors prevented food contamination while insisting their mission was essential to the performance of the military, and they sought to limit the spread of sexually transmitted diseases among military personnel. And the agency performed these tasks while it continued-and expanded-its role of issuing social security benefit checks, providing medical services to underserved American communities, screening new drugs, and printing books for the blind. ${ }^{20}$

As the FSA's origins recede into history, however, scholars too have remained blind to certain puzzles about its birth, which are also reflected in the story of the birth of DHS. ${ }^{21}$ Why, for instance, did President Roosevelt create the FSA at all, particularly when doing so involved such an expenditure of scarce political capital and resulted in the removal of some bureaus from agencies where they were already supervised by trusted political lieutenants? The meager scholarly literature on the subject, much of it written at the time of the merger or shortly thereafter, speculates that the president's interest was in more "efficient" government without defining the concept or considering the more directly political implications of the White House move. Why did the agency so pervasively mix social welfare, regulatory, and national security functions, years before World War II embroiled the United States? Indeed, what was meant by the reference to "security" used to justify expansive legal powers in the early years of the FSA? And how did the FSA's creation impact the work of its bureaus? $?^{22}$ In one of the

20 See Parts III-IV. See also Office of Government Reports, US Information Services, United States Government Manual, September 1941 364-86 (GPO 1941) (describing the activities of the FSA); Federal Security Agency, Services of the Federal Security Agency 4, 8, 10-11, 16 (GPO 1944) (same). The treaty the United States had signed outlawing such work was The Geneva Protocol for the Prohibition of the Use in War of Asphyxiating, Poisonous, or Other Gases, and of Bacterial Methods of Warfare, 26 UST 571, TIAS No 8061 (1925) ("Geneva Protocol"). Although the United States had not ratified the treaty at the time, its signature would have presumably been understood to be a commitment not to frustrate the purposes of the treaty. See Edward $\mathrm{T}$. Swaine, Unsigning, 55 Stan L Rev 2061, 2061-62 (2003).

21 Surprisingly, the massive body of literature on the history of the American state during and after the New Deal all but ignores the FSA. The same is true for the somewhat smaller yet still substantial literature on regulatory governance before the 1946 passage of the Administrative Procedure Act. But the FSA's trajectory can be reconstructed from White House records, legislative documents, budget reports, and the agency's own files.

22 The President's Committee on Administrative Management, commonly known as the Brownlow Committee, provided a prescriptive, public administration justification but does not explain why the president would expend the resources he did to implement parts of that vision. See generally James W. Fesler, The Brownlow Committee Fifty Years Later, 47 Pub Admin Rev 291 (1987). With respect to the supervision of transferred bureaus by political supporters, bureaus such as Education and the PHS were not - in contrast to the SSB -independent commissions that might have triggered obvious concerns about political control. They were instead bureaus in departments overseen by White House loyalists such as Harold Ickes and Henry Morgenthau, Jr. See Richard Polenberg, Reorganizing Roosevelt's Government: The Controversy 
few scholarly references that are relevant to the subject, political scientist James Q. Wilson downplays the importance of the creation of HEW for the behavior of its component bureaus. But he does nothing to investigate the potential significance of the time those bureaus spent within the FSA, or the broader legacy of that agency. ${ }^{23}$

The answers to these puzzles implicate not only separation of powers and national security law, but also organization theory and the history of the administrative state. First, organizational changes can exert powerful, underappreciated influence on law's implementation. Public health bureaucrats work differently when buried in a Treasury Department dominated by fiscal concerns than when operating in an agency prioritizing health and economic security. Because organization is not neutral, the redistribution of authority within the executive branch can shape the law by facilitating a symbiotic burst of agency capacitybuilding coupled with presidential power to control that new capacity. Roosevelt's creation of the FSA had major practical effects, and those effects went far beyond political symbolism. The agency created a layer of bureaucratic appointees allowing the president to have more control over important administrative agencies at a time when its staff was meager and the agencies were previously either independent (as was the SSB) or stuck in departments unsympathetic to their missions (as was the PHS under the Treasury). The new layer of political appointees and lawyers allowed the administration to wring the maximum benefit

over Executive Reorganization, 1936-1939 82 (Harvard 1966); Felix Belair, Jr, President Decrees Three Big Offices in Centralizing 21, NY Times 18 (Apr 26, 1939). It is also unusual for a president to transfer agencies from traditional executive departments-generally considered to be more tightly under presidential control - to an independent agency such as the early FSA. See David E. Lewis, Presidents and the Politics of Agency Design: Political Insulation in the United States Government Bureaucracy, 1946-1997 143-44 (Stanford 2003). Regarding the efficiency-focused rationales for reorganization, see Polenberg, Reorganizing Roosevelt's Government at 3-5. Interestingly enough, Polenberg also reports that Roosevelt privately disparaged efficiency rationales for reorganization (even as he was willing to publicly espouse them). See id at 8, 33-34. The efficiencyfocused explanations that so heavily draw on prescriptive scholarship in a "public administration" tradition suffer from limitations. First, they are provided with little or no empirical support. Second, they do not consider the full scope of the FSA's legal powers, or the president's special concern for these functions. Finally, they do not place the discussion in the political context of the times, including the battle over Roosevelt's reorganization plans and the emerging war-related rhetoric of the administration at the time.

23 Wilson dismisses the significance of the creation of HEW in 1953. See James Q. Wilson, $B u$ reaucracy: What Government Agencies Do and Why They Do It 267-68 (Basic 1989) ("[A]ssembling a variety of agencies together into a Department of Health, Education, and Welfare made little difference: the component bureaus, each with its distinctive culture, professional outlook, and congressional supporters, continued for the most part to operate independently of each other and of HEW's central leadership."). But he fails to address the potential significance of the creation of the FSA a decade and a half before, and even his account of the relative insignificance of HEW's creation is difficult to reconcile with the degree of conflict over this change and the internal administrative implications of elevating the FSA to cabinet status. 
out of broad legal authorities, to monitor developments in the bureaus, to harness the bureaus' analytical capacities in the service of further legislative changes, and to ensure that they spoke with a more consistent voice to promote favorable public perceptions. In short, reorganization gave the White House more control, and more to control.

Second, agency architecture can help reshape public perceptions of the government's legal responsibilities. Aware of the looming possibility of war, Roosevelt used his new degree of control over bureaucratic functions to frame discussion about the concept of "security"-defining it broadly enough to blur the distinctions between social services, economic security, health regulation, and geostrategic national security. Doing so served a political goal by giving moderate legislators skeptical of social programs but supportive of defense a new reason to support the FSA bureaus, and by reinforcing associations among many voters between national security goals and regulatory and social programs. With its new political and legal staff, its two-edged "security" mandate, and its relentless efforts to explain the essential importance of its work to the public, the FSA seemed to prosper during and after the war. It was able to keep and even grow its budgets during a wartime period when other domestic agencies faced cuts in their budgets; it achieved expansions in its responsibilities (particularly in social security and health research) at a time when Congress was often hostile to the administration; and the public increasingly supported the transformation of the organization into a cabinet agency.

Third, the story of the FSA shows the malleability of the "security" concept in relation to law. Parallel to the aforementioned developments, the Roosevelt administration's melding of functions within the FSA proved a harbinger for a conception of security that became increasingly identified with the military and national defense, to the point where that powerful association swallowed up the more flexible conception that Roosevelt first championed. In effect, Roosevelt's reorganization set in motion a process showcasing the connections between three dynamics: public debates about "security" as a metaphor for the responsibilities of the modern nation-state, changes in organizational structure to bolster a particular understanding of "security," and political strategies to control the law's implementation. Such contestation belies the idea of security as an unambiguous prescriptive rationale for legal changes, raising often-neglected questions about the scope of national security law. As presidents, lawmakers, courts, and the public struggle with those questions, the fight over "federal" security in the Truman years provides a provocative reminder that the notion of security-in part because of its deep connections to the underlying origins of the nation-state itself-should be subject to as much contestation as conceptions of democracy or citizenship. Yet despite the legal stakes of de- 
fining security in contexts ranging from application of the Homeland Security Act of $2002^{24}$ to the scope of deference to the executive, scholars of national security law rarely address or even recognize the fundamental question of how to define security in the modern nation-state.

Fourth, the problem of regulating organizational structure permeates - and perhaps inevitably defines - modern separation of powers. Presidential control of agency architecture-including who runs the agency, what bureaus are within it, how the public views those bureaus, and who (other than the president) runs the bureaus - can substitute for direct presidential power to command subordinate officials. The consequences of structural innovation, moreover, show robust "presidential administration" to be in fact a longstanding phenomenon, one that courts should regulate when policing the border between legislative and executive authority.

Laying the groundwork for these observations, Part I retraces the now-forgotten evolution of the FSA. It describes the political and economic context in which it was created, its mix of domestic administrative and national security responsibilities, and its path towards eventual cabinet status. Given the complexity of the situational context, the analysis uses primary sources, legal materials, budget data, and comparisons with other agencies to reveal a composite, though necessarily partial, image of the reorganization's intricacies. ${ }^{25}$ Part II begins the process of interpreting the FSA's trajectory. The discussion emphasizes how organizational changes can enhance executive control by building bureaucratic capacity and bolster political coalitions supporting the execution of legal mandates. Part III applies the new perspective to the history of the FSA and finds considerable empirical support for it. Part IV addresses larger implications, such as the ambiguities inherent in how presidential administrations have used the concept of "security" to bolster political coalitions.

Ultimately, these precedents hint at how the recent spike of interest in "homeland security" is furnishing similar opportunities to remake

24 Homeland Security Act of 2002, Pub L No 107-296, 116 Stat 2135, codified at 6 USC $\S 101$ et seq.

25 More specifically, this Article uses three techniques to shed light on the trajectory of the FSA: First, it investigates how participants in the drama viewed the situation at the time of the FSA's creation and during its subsequent history. Second, it contrasts, where possible, the FSA to other agencies operating during its existence. The analysis also contrasts the situation present with regard to the execution of some of the FSA's legal mandates before and after the agency was created. Third, this Article uses theoretical insights grounded in existing empirical and analytical literatures to interpret the significance of particular events associated with the creation of the FSA, such as the formation of a cadre of political appointees to run the new agency. Together these approaches provide a richer picture than what could be obtained from a purely historical narrative or from large- $n$ studies of bureaucratic structure. 
the domestic regulatory state. Today's world of elaborate infrastructure problems, global nonstate actors, and mature regulatory agencies renders the historical context different. The George W. Bush administration's narrow substantive definition of security, with implications that tend to cut against expansive regulatory activity in domains such as environmental protection or federal involvement in providing health services, is also different. ${ }^{26}$ But the cycle epitomizing fundamental conflicts over the architecture of law is not: policymakers mold law by defining security and then seek to command law's implementation by securing control over bureaucracies.

\section{THE EVOLUTION OF THE FSA}

Even the singularly optimistic Franklin Delano Roosevelt could have a bad turn. By late 1938, the disappointed president would have been hard-pressed to deny that he was having one. Gone were the heady days of the early New Deal coalition, when Roosevelt had created the massive National Recovery Administration, the Agricultural Adjustment Act, dozens of the agencies, and major banking reform. The administration had drawn down its reservoirs of political capital. Roosevelt's infamous judicial reorganization plan, already tarred as a "court-packing plan," had been defeated. And the legislature had also dealt him a blow by rejecting his executive reorganization plan."

26 See Dara K. Cohen, Mariano-Florentino Cuéllar, and Barry R. Weingast, Crisis Bureaucracy: Homeland Security and the Political Design of Legal Mandates, 59 Stan L Rev 673, 681 n 24 (2006) (discussing the Bush administration's narrow definition of "security" and the resulting domestic policy implications). See also Homeland Security Council, National Strategy for Homeland Security 3 (Oct 2007), online at http://www.dhsgov/xlibrary/assets/nat_strat_homelandsecurity_2007.pdf (visited Apr 14, 2009) (defining homeland security as "a concerted national effort to prevent terrorist attacks within the United States, reduce America's vulnerability to terrorism, and minimize the damage and recover from attacks that do occur").

27 Regarding Roosevelt's political difficulties by the end of the 1930s, see Warren B. Francis, President's Influence Is Slipping As Solons Labor, LA Times A5 (May 21, 1939). Published at precisely the time Roosevelt was contemplating his reorganization plans, the article notes:

In the last month particularly rebuffs for Mr. Roosevelt have been frequent and irritating. The spirit of revolt is spreading steadily. Aware they can defy the administration with impunity, increasing numbers of Democrats are balking at New Deal proposals. Such a tendency was responsible for defeat of the Florida ship canal bill and of the plan to subsidize cotton exports; it was the factor behind the boost in flood-control funds and the rebellion against the Wage-Hour Act amendments.

Id. This perception was widely shared among press observers and politicians at the time, as well as subsequent scholarly observers. See William E. Leuchtenburg, Franklin D. Roosevelt and the New Deal, 1932-1940 252 (Harper \& Row 1963). These difficulties are probably better explained by the administration's strategic decisions to obtain greater policy successes by shedding marginal coalition members than by secular declines in Roosevelt's popularity or political acuity. See James L. Sundquist, Dynamics of the Party System 199-214 (Brookings 1973) (discussing evidence that Roosevelt accepted a "measurable" loss of conservative, rural Democrats to the Republican ranks as a result of his New Deal policies). With respect to the first puzzle, it is worth noting that the 
The administration's plan to give the president control over where bureaus would fit in government had been soundly defeated along with his plan to create a new Department of Public Welfare around the nascent SSB. ${ }^{28}$ His party controlled the legislature, to be sure, but the increasing prominence of an alliance between conservative Southern Democrats and Republicans had greatly complicated his efforts to reshape the structure of government. The government was growing, the president explained to legislators. No one could be expected to administer it efficiently with such a vast number of regulatory commissions and independent agencies. The New Deal's legislative opponents even made the point themselves often enough; where they differed with the president was in recommending a thorough pruning of government agencies-eliminating regulatory and administrative bodies instead of consolidating their powers. After all, scores of administrative agencies were initially described as temporary, and there were other pressing matters besides domestic social welfare and regulation-such as the deteriorating international security picture in Asia and Europe - that seemed to command the nation's attention. ${ }^{30}$

And it was not only legislators that Roosevelt had to worry about, as the torrential arguments over reorganization had flowed from legislative debates into the public sphere. Civic organizations opposed to the New Deal had made the president's quest for executive reorganization a centerpiece of their campaign against him." "Dictatorial" was increasingly the label given to the president's aspirations, and the drive for reorganization was allegedly the quintessential evidence. ${ }^{32}$ So successful had these associations been in drumming up opposition to reorganization that it seemed difficult to imagine the president's legislative agenda recovering from this low ebb.

Brownlow Committee provided a prescriptive, public-administration justification but did not explain why the president would expend the resources he did to implement parts of that vision.

28 See Polenberg, Reorganizing Roosevelt's Government at 146-55 (cited in note 22) (discussing Roosevelt's declining popularity and how it was hurting his ability to implement his reorganization plans).

29 See Part III.B.2

30 See Leuchtenburg, Franklin D. Roosevelt and the New Deal at 231-40,275 (cited in note 27).

31 Polenberg, Reorganizing Roosevelt's Government at 55 (cited in note 22) (discussing growing efforts by anti-New Deal organizations to capitalize on the administration's political vulnerability and perceived presidential overreaching during the reorganization fight). Polenberg notes:

On a Sunday morning in March 1938 a farmer in Muscatine, Iowa, received several special delivery letters. Sent by Frank Gannett's national Committee to Uphold Constitutional Government, they contained broadsides blasting the Reorganization bill as a "colossal snatch ... for Presidential power," as a scheme to clamp "one man rule upon a free people." Id at 55-56.

32 See id (discussing how opposition grew when FDR proposed enlarging the size of the Supreme Court). 
Two years later, President Roosevelt had confounded his opponents. Not only did he have much (though not all) of the reorganization authority he craved, but he had immediately used it to create an agency focused on health and social welfare that was-in some respects-even more ambitious than the one he first proposed. The new Federal Security Agency lacked cabinet status and was short of funds in 1940. But within its bureaus lay the seed of an elaborate legal machinery that would become a quintessential twentieth-century bureaucratic institution. ${ }^{33}$

\section{A. The Case, Some Puzzles, and Its Context}

Public law in modern nation-states is largely about what bureaucratic institutions do. And because law is nearly always administered through such massive public bureaucracies, the history of the federal government is in some measure the story of how its bureaucracies grew in statutory power, budget, and administrative scope. Nearly all of the major agencies in the federal government have interesting stories, capable of revealing subtleties about the emerging American state. But the FSA merits special attention, even when considered alongside the panoply of "unorthodox" administrative formulas that Roosevelt's minions routinely deployed to control the law's execution during the New Deal.

First, it eventually spawned the massive Department of Health, Education, and Welfare. Even at the time of its creation, the FSA was among the largest agencies both in terms of appropriations and employees, despite the fact that it lacked cabinet status. By understanding developments in that important context, we may learn something more about how presidents control bureaucratic functions amid legal constraints imposed by congressional enactments as well as substantive statutory mandates.

Second, efforts to create an agency to centralize health, welfare, and security activities were shrouded in controversy in this country. Theda Skocpol discusses failed efforts to create such an agency in the nineteenth century. ${ }^{34}$ Roosevelt, dragged down by the court-packing

33 See Miles, The Department of Health, Education, and Welfare at 20 (cited in note 13) ("Even though HEW's official birth did not occur until 1953, when FSA's name was changed and its head became a Cabinet officer, [the formation of the FSA] was the real beginning of the Department of Health, Education, and Welfare.").

34 Regarding previous fights to centralize functions in a health and welfare ministry, see Theda Skocpol, Protecting Soldiers and Mothers: The Political Origins of Social Policy in the United States 304 (Harvard 1992):

In the end, various bills ... to establish a new national Department of Public Health, were deflected or defeated in Congress between 1908 and World War I. The nation was left with a consolidated Public Health Service, but without an omnibus health agency. Since the reformers had hoped that a new federal agency would stimulate and coordinate state and local health efforts and lay the evidentiary basis for new programs, the failure of the statebuild- 
fight, failed at his first attempt to create such a cabinet-level agency in 1938. In effect, Roosevelt's predecessors failed, and even the politically dexterous president was rebuffed when he attempted to do so directly. Afterwards he tried to do the next-best thing. By creating an independent, noncabinet agency, the evolving bureaucracy eventually came to encompass even more than what Roosevelt himself had initially sought to include within it. Nor did the fighting over the FSA stop during the Roosevelt administration. Later, once the FSA made the idea of a unified health, welfare, and security agency a reality, President Harry S. Truman marshaled the agency's resources to promote his national health insurance plan. Yet, in part for that reason, he failed to obtain support for cabinet-level status from a Republican Congress. Truman tried and failed to elevate it to cabinet status, a change that President Dwight D. Eisenhower eventually succeeded in achieving in 1953 as the first major legislative achievement of his Presidency.

By contrast, the British forged a Ministry of Health by 1919 on the heels of a costly victory during World War I. Through it, the British radically reshaped local control of social services and promptly began advocating for expanded health benefits. ${ }^{36}$ But beyond changing the lines of authority for existing functions, creation of a new ministry was understood by some observers as changing the government's capacity to reshape the legal determinants of health policy. Wasting little time in displaying his ambitions for the new ministry, Dr. Christopher Addison (the new health minister) explained: "The object of the new ministry is, of course, to provide better health services throughout the country, and we are now working on our health programme; and various proposals will be submitted to the consultative councils at no distant date.,"37 The presence of these controversies and the trajectory of health, security, and welfare policy in comparative perspective suggest that it is important to understand the story of the FSA and its progeny in order to explain important legal and policy developments involving health, welfare, and security.

Third, the story of the FSA illuminates the elusive content of the term "security," a now ubiquitous concept defining a major category of government responsibility. As the analysis below suggests, the use of the term "security" to anchor the agency's name and so many of its func-

ing effort certainly weakened the plausibility of the ... campaign during 1916-1920 for public health insurance in the United States.

35 See Miles, Department of Health, Education, and Welfare at 25-28 (cited in note 13).

36 See William S. Carpenter, England's New Ministry of Health, 13 Am Polit Sci Rev 662, 662 (1919) (discussing Parliament's new act, which took control of health away from local government and put it in a ministry).

37 Id at 664.

38 See Part I.C-D. 
tions was no accident. It was not a mere reference to an established social security bureaucracy; "security" had often been deployed to describe the goal of economic relief programs, but it had also been deployed in connection with defense-related activities. The concept itself remained ambiguous, waiting for policy entrepreneurs to fill in the blanks. Fights about how to fill in those blanks have been central in the creation of other major federal agencies, such as the modern Departments of Energy and Homeland Security. By tracing the progression that took the FSA from a scattered cluster of bureaus into the preeminent domestic policy agency of twentieth-century America, we can learn something about how the content of "security" was written by political actors and how it may yet again be rewritten."

These puzzles reveal deeper gaps in our knowledge about the effect of bureaucratic structure on law's evolution. Lawsuits sometimes turn on how legal authority is divided across public bureaus. ${ }^{40}$ Lawmakers struggle to control that allocation. ${ }^{41}$ Lines of organizational jurisdiction over legal mandates may determine who has power to interpret and implement the law as much as lines of geographic jurisdiction define the boundaries of nation-states or localities. ${ }^{12}$ Yet we know little about precisely how changes in bureaucratic structure affect the implementation of legal mandates, how presidents control the immense powers of a sprawling executive branch, and how the competition to shape the meaning of concepts such as "security" among the public and legislators may play out in the intricate boundaries that are created by politicians to allocate bureaucratic jurisdiction over the legal powers of the federal government. Closing some of these gaps depends in part on closely scrutinizing the institutional choices consolidating power in agencies such as the FSA.

The first few pages of the FSA's own history were written in what was, from President Roosevelt's perspective, a political environment that was becoming increasingly difficult to control.

39 See Part I.D.

40 See Food and Drug Administration v Brown \& Williamson Tobacco Corp, 529 US 120, 161 (2000) (resolving whether the FDA had jurisdiction over tobacco); Isbrandtsen-Moller Co $v$ United Sates, 14 F Supp 407, 412-13 (SDNY 1936) (dismissing a complaint to prevent the president from abolishing the Shipping Board Bureau and transferring its power to the Department of Commerce), affirmed, 300 US 139, 149 (1937).

41 See Cohen, Cuéllar, and Weingast, 59 Stan L Rev at 699 (cited in note 26) (discussing the lack of congressional reorganization).

42 See Part II

43 See Part I.A and Part I.D for a discussion of this historical trajectory. 
During the first six or seven years of his Presidency, Roosevelt's administration unleashed major changes in the federal government." The precise extent to which these changes represented a radical break with the past is a matter of some debate among scholars, but the fact that he created a massive number of new administrative agencies with farreaching legal powers is not." It is this latter fact that becomes immediately important to our account, since it gave rise to three interrelated political debates that culminated in the latter part of Roosevelt's second term. The first was whether the amalgam of new agencies-often initially justified as temporary and allowed to function independently in part (according to the White House itself) as a means of getting them off the ground quickly - should ultimately be abolished. The second was whether the president should have executive authority to reorganize the functions of the executive branch-including independent agencies and departmental subunits. Eventually he gained that authority, and he used it to create a sprawling new agency called the Federal Security Agency. The third was whether the president could fire commissioners appointed to fixed terms, such as those who served in the FTC, the SEC, and the SSB. President Roosevelt craved such firing authority. But the Supreme Court proved hostile to this move. ${ }^{46}$ This gave the White House even greater reason to concoct new strategies, perhaps involving reorganization, to gain power over the independent agencies.

And that power often seemed well within the president's grasp. The president's popularity had attained commanding heights between 1933 and 1937. But he was not immune from conventional political pressures. During the early phase of his Presidency, when the banking crisis and uncertainty about Roosevelt's own intentions were most pronounced, the new president analogized the nation's economic problems

44 See Leuchtenburg, Franklin D. Roosevelt and the New Deal at 335 (cited in note 27):

By the end of the Roosevelt years, few questioned the right of the government to pay the farmer millions in subsidies not to grow crops, to enter plants to conduct union elections, to regulate business enterprises from utility companies to airlines, or even to compete directly with business by generating and distributing hydroelectric power.

See also Mathew D. McCubbins, Roger G. Noll, and Barry R. Weingast ("McNollgast"), The Political Origins of the Administrative Procedure Act, 15 J L, Econ, \& Org 180, 190-91 (1999) (analyzing how expansion in federal power exacerbated efforts to control the bureaucracy).

45 For different perspectives on the extent to which the New Deal represented a "sharp break" from the previous legal regime, compare Bruce Ackerman, Constitutional Politics/Constitutional Law, 99 Yale L J 453, 456 (1989) (describing the New Deal as one of the "great constitutional transformations"), with Michele L. Landis, Fate, Responsibility, and "Natural" Disaster Relief: Narrating the American Welfare State, 33 L \& Socy Rev 257, 259-61 (1999) (questioning Ackerman's and other scholars' view of the New Deal by arguing that it followed precedents in disaster relief situations).

46 President Roosevelt's efforts to fire independent commissioners spawned Humphrey's Executor, 295 US 264 (1935). 
to a foreign invasion. ${ }^{47}$ As a consequence, he reasoned, the president would need to deploy powers associated with a national security emergency to address the problems afflicting the nation. By framing the emergency in these terms, the president seemed to be achieving two separate goals. He was emphasizing his administration's contrast to the previous one in recognizing the severity of the crisis. Simultaneously, he was promoting a favorable background political context for his legally questionable decision to invoke wartime statutory powers, such as those contained in the 1917 Trading with the Enemy Act, ${ }^{48}$ to respond to the economic emergency. The president's strategic efforts to blur the distinction between domestic and national security crises served as important political precursors to his subsequent decisions about how to organize the government's policy functions. ${ }^{\text {s. }}$ Those efforts would not be forgotten.

By mid-1938 the administration faced new political challenges. It had achieved major legislative changes, including passage of the Social Security Act and the Food, Drug, and Cosmetic Act of 1938. But the cohesiveness of the New Deal coalition was affected by lingering economic weakness and increasingly shrill public attacks from political opponents. ${ }^{\text {s1 }}$ At first, some of its apparent loss of political support in Congress probably reflected the administration's boldness-fueled by the size of its victories in the 1936 elections -in seeking legislative proposals that might have been controversial even among moderate supporters of the New Deal. Such a pattern is consistent with passage of the Wagner Act and the Food, Drug, and Cosmetic Act, for example. Nonetheless, whether because of deliberate administration choices to press its political advantage, secular trends, or economic problems, the administration's public standing was deteriorating by 1938 . There was a recession that began around mid-1937 at the latest. ${ }^{52}$ The courtpacking fight saturated the country with charges that Roosevelt was an aspiring dictator and polarized otherwise progressive civil liberta-

47 See Jonathan Alter, The Defining Moment: FDR's Hundred Days and the Triumph of Hope 3 (Simon \& Schuster 2006) (explaining that the greatest applause during Roosevelt's first inaugural speech came when he asked for powers to combat the emergency as if it were a "foreign foe").

48 Trading with the Enemy Act, Pub L No 65-91, 40 Stat 411 (1917), codified in various sections of 50 USC App.

49 See Kenneth W. Dam, From the Gold Clause Cases to the Gold Commission: A Half Century of American Monetary Law, 50 U Chi L Rev 504, 510 (1983) (discussing Roosevelt's early use of the Trading with the Enemy Act to prohibit banks from paying out or exporting gold coin or bullion).

50 See William E. Leuchtenburg, The FDR Years: On Roosevelt and His Legacy 59-65 (Columbia 1995) ("In carrying the legislation of the First Hundred Days into effect, Roosevelt took full advantage of the receptivity of the country to wartime appeals.").

51 See Leuchtenburg, Franklin D. Roosevelt and the New Deal at 253-73, 277 (cited in note 27) (describing the slow economic recovery in 1938).

52 See id at $244-46$. 
rians against him. ${ }^{53}$ It was perceived and reported on as a political failure in the president's relationship with Congress and an example of alleged presidential lust for power, lending credence to critics who painted the president as an aspiring dictator. By the time the first executive reorganization bill was voted on, even nonmarginal Democratic legislators who voted for the Wagner Act were ignoring Roosevelt's entreaties and voting against the White House on reorganization. ${ }^{54}$

Political realities were reflected in Roosevelt's mixed record of success and failure. By the middle of his second term, the president had plainly succeeded in the broad outlines of his policy goals-creating transformative new policy and regulatory programs such as the SSB, the SEC, the Tennessee Valley Authority, and the Works Progress Administration. Congress had just approved a potentially sweeping Food, Drug, and Cosmetic Act, expanding the government's power to regulate growing industries. ${ }^{55}$ But as the cycle of the Roosevelt Presidency unfolded, organized interests disagreeing with the administration over economic policy increasingly asserted themselves. Opposition also grew among the public and the elites in the South who frowned on the sharp expansion in federal power. The disaffected Southern Democrats, in turn, were joined in growing numbers by many wealthy Americans throughout the country opposed to Roosevelt's regulatory and social welfare policies.

The political trends in public opinion and media coverage tended to affect legislators' willingness to support the president in swing districts. As public and media support weakened during the president's second term, he lost support in Congress. Changes in the composition of the legislature in absolute terms also weakened the extent of support

53 See Polenberg, Reorganizing Roosevelt's Government at 55-56 (cited in note 22).

54 See id at vii ("In April 1938 more than one hundred Democratic congressmen deserted President Roosevelt to defeat the [first] Executive Reorganization bill by a vote of 204 to 196."). Regarding Roosevelt's declining political fortunes, see Leuchtenburg, Franklin D. Roosevelt and the New Deal at 271 (cited in note 27) (discussing GOP gains in 1938); Francis, President's Influence Is Slipping As Solons Labor, LA Times at A5 (cited in note 27) (describing Roosevelt's political influence as "ebbing"); Sundquist, Dynamics of the Party System at 200-01 (cited in note 27) (discussing the shedding of marginal coalition members). For a theoretical perspective on when leaders such as Roosevelt might prefer to shed marginal coalition members and when they might opt to maintain the largest possible winning coalition, see Barry $\mathrm{R}$. Weingast, Reflections on Distributive Politics and Universalism, 47 Polit Rsrch Q 319, 324 (1994) (comparing universal or nearunanimous coalitions with the reality of divisive political parties).

55 See generally David F. Cavers, The Food, Drug, and Cosmetic Act of 1938: Its Legislative History and Its Substantive Provisions, 6 L \& Contemp Probs 2 (1939).

56 See Polenberg, Reorganizing Roosevelt's Government at 56-58 (cited in note 22) (discussing wealthy supporters, including newspaper publisher Frank Gannett and New York lawyer Amos Pinchot, of civil society movements opposing the New Deal); id at 64 (discussing Southern Democrats' opposition to Roosevelt's plans). Regarding the significance of the Food, Drug, and Cosmetic Act, see generally Janice Dee Gilbert, The United States Food and Drug Administration: Purpose, History, and Function (Vance Bibliographies 1982). 
the president had previously achieved in Congress. ${ }^{57}$ The result of these changes was increasing frustration of the president's political agenda on Capitol Hill, most obviously demonstrated by the fate of the "courtpacking" plan but also evident in the delay the White House faced in achieving broad powers to reorganize government agencies.

Adding to White House concerns was the evolving direction of legal doctrine governing the president's relationship with the national government that he had vigorously fought to create. Since the 1920 s, courts had increasingly taken up questions about the scope of executive power, complicating the prospects for full presidential control of the

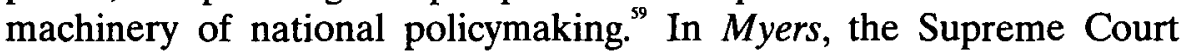
recognized presidential primacy in controlling senior officials with core executive functions when it invalidated limitations on presidential firing powers and prohibited other forms of excessive congressional encroachment. ${ }^{60}$ But this decision also acknowledged congressional power to protect inferior officials through civil service protectionsbeyond appearing to outlaw schemes requiring congressional assent to fire federal officials-and gave little guidance on how to define core executive functions. ${ }^{61}$

Given such ambiguity and the enormous congressional efforts to protect new agencies from direct presidential control, the subsequent legal showdown over executive power in Humphrey's Executor should have been entirely predictable. There, the Court upheld congressional power to prevent fixed-term commissioners of independent agencies such as the FTC from being forced to leave their jobs before their terms were up. Without explicitly overruling Myers, the Humphrey's Executor Court sought to distinguish the present case on the basis of the FTC's status as an agency of mixed (executive and legislative) func-

57 See Polenberg, Reorganizing Roosevelt's Government at 146-61 (cited in note 22).

58 Regarding the impact of presidential popularity on legislative behavior, see Douglas Rivers and Nancy L. Rose, Passing the President's Program: Public Opinion and Presidential Influence in Congress, 29 Am J Polit Sci 183, 194-95 (1985). With respect to how this played out in the New Deal context, see Polenberg, Reorganizing Roosevelt's Government at $146-61$ (cited in note 22) (detailing how Roosevelt's influence in Congress fell as his popularity did in the late 1930s); Floyd M. Riddick, American Government and Politics: Third Session of the Seventy-sixth Congress, January 3, 1940 to January 3, 1941, 35 Am Polit Sci Rev 284, 303-04 (1941) (summarizing that Roosevelt vetoed 107 bills that year as Congress increased its opposition to his policies); Francis, President's Influence Is Slipping As Solons Labor, LA Times at A5 (cited in note 27) (describing Roosevelt's decreasing influence as even Democrats began denying New Deal proposals).

59 See Reuben Oppenheimer, The Supreme Court and Administrative Law, 37 Colum L Rev 1,1-2 (1937) (acknowledging increases in how contentious the issues of executive power became in litigation between the 1920s and the 1930s).

60272 US at 175-76.

61 See Elena Kagan, Presidential Administration, 114 Harv L Rev 2245, 2322 (2001) (discussing the extent to which Myers left unresolved matters that were taken up in Humphrey's Executor).

62 Humphrey's Executor, 295 US at 624-26. 
tions. ${ }^{63}$ If Myers bequeathed a legacy of uncertainty about precisely what counted as core executive functions undertaken by senior officials, at a conceptual level, Humphrey's Executor left unresolved the matter of what exactly counted as sufficient mixing of functions. At a practical level, however, Humphrey's Executor left unchallenged congressional efforts to greatly complicate presidential control of the executive branch. And it was little consolation, surely, that lower courts at the time were accepting fairly broad readings of presidential statutory power to reorganize agencies. In Istbrandtsen-Moller v United States ${ }^{54}$ for example, a district court found that statutory presidential reorganization authority extended not only to traditional executive bureaus but also to boards and commissions such as the US Shipping Board, which straddled the divide between legislative and executive power. ${ }^{65}$ But that power was subject to some congressional control and had in fact expired by the end of $1935 .^{66}$ This left the president facing an environment where a growing proportion of a swelling federal government involved difficult-to-control independent commissions, yet his own statutory power to shape the operation of that government through reorganization had expired at a time when his political fortunes were becoming more complicated.

The effect of the president's more difficult political and legal position was plainly apparent in the fight over executive reorganization. Previous law from the early 1930s created limited reorganization authority. ${ }^{6}$ That law undoubtedly whetted Roosevelt's appetite for broader powers to reshape the architecture of an executive branch that had grown piecemeal through executive compromise with Congress. In 1938, the White House introduced a sprawling original bill modeled on the recommendations of the President's Committee on Administrative Management, commonly known as the Brownlow Committee. This body of scholars had conveniently elided distinctions between "efficiency" and presidential control. The bill called for the creation of two cabinet departments-including a Department of Welfare that would have included all or much of what ended up in the FSA - and made no provision for a congressional veto. (For example, some action from both

63 Id at 629 (noting that officials outside of the executive branch need to be "free from control or coercive influence").

6414 F Supp 407 (SDNY 1936).

65 Id at 412-13.

66 See Polenberg, Reorganizing Roosevelt's Government at 8 (cited in note 22).

67 See Executive Department Reorganization Act of June 30, 1932, Pub L No 72-212, 47 Stat 413, amended by 47 Stat 1517 (1933). The Act allowed the president to transfer agencies and their legal responsibilities to different departments, subject to a one-house legislative veto in most circumstances. But soon after passing the law in 1932, congressional leaders passed an amendment limiting the validity of any reorganization plans after two years unless otherwise provided by Congress 
houses would have been required to stop a reorganization plan.) Nor did the original plan exempt independent regulatory agencies. ${ }^{8}$ The resulting bill had two-house veto provisions for reorganization plans, exempted the independent agencies, and had authority that was set to expire after several years. ${ }^{\infty}$

Roosevelt intensely supported the plan. His introduction of the reorganization bill generated considerable fanfare among supporters in the House and Senate. ${ }^{70}$ One academic observer later described the introduction of the reorganization bill as a study in masterful presidential strategy. ${ }^{71}$ Highlighting the fact that Congress itself had chartered the commission that recommended the sweeping reorganization reforms, the president introduced a package that would have allowed him to reorganize executive branch agencies without the two-house veto provision that appeared in the watered-down 1939 bill. The earlier bill allowed for the creation of two cabinet departments-including a Department of Public Health and Welfare that would include responsibility for federal pensions, social security, rural relief activities, and public health. Despite the concerns of some lawmakers, the bill made no provision for a congressional veto. Nor did it exempt independent regulatory agencies from being subjected to reorganization. ${ }^{2}$

Two further details about the reorganization fight are worth noting. First, after the introduction of the president's original bill (which was essentially the Brownlow Committee proposal), the legislative process produced a slew of amendments to the bill. ${ }^{13}$ But the White House pushed back, impressing the legislative leadership with the importance of slowing down or blocking votes on changes that could result in a substantially weaker bill. ${ }^{74}$ As a result, these amendments did not result in a compromise bill that could have simultaneously commanded support among winning legislative coalitions and the White House. Second, the White House and its top political staffers insisted that the president would not discuss specific reorganization plans, making it easier for

68 See generally 83 Cong Rec S 2497 (Feb 28, 1938).

69 Compare Executive Reorganization Act, S 3331, 75th Cong, 3d Sess (1938) (containing more ambitious policies but rejected by the House), with Reorganization Act of 1939, Pub L No 76-19, 53 Stat 561 (containing less ambitious policies, including a two-house veto).

70 See Polenberg, Reorganization Roosevelt's Government at 188 (cited in note 22).

71 See id.

72 For a discussion of the principled rationales the president sought to deploy to bolster the case for reorganization, see Lloyd M. Short, Adjusting the Departmental System, 41 Am Polit Sci Rev $48,50-52$ (1947) (describing the various suggestions for reorganization from the Brookings Institution, hired by the Senate, and the president's committee). Regarding the president's masterful performance, see Polenberg, Reorganizing Roosevelt's Government at 188 (cited in note 22) (elaborating on the success of Roosevelt in reorganizing the government even with earlier failure).

73 See Polenberg, Reorganizing Roosevelt's Government at 185-88 (cited in note 23).

74 See Louis Brownlow, A General View, 1 Pub Admin Rev 101, 105 (1941). 
opponents to dramatize the potential for "dictatorship" and harder for supporters to point to specific savings or "efficiency" gains that could be achieved through consolidation. ${ }^{75}$

But vigorous opposition soon emerged in both houses. The underlying logic of that opposition appears to reflect two mutually reinforcing dynamics that together contributed to the deteriorating prospects for Roosevelt's reorganization plan. One dynamic is about signaling and symbolism, suggesting that opposition to the reorganization plan swelled because it was simply the best issue for opponents to rally around. ${ }^{76}$ Second, there is a more directly political story rooted in the prospect that reorganization had the potential to bestow upon Roosevelt significant powers that could change the amount and tenor of federal administrative activity. Both almost certainly played a role. The reorganization bill became a rallying point for opponents of the New Deal. A self-styled National Committee to Uphold Constitutional Government, fresh from its perceived victory during the court-packing fight flooded the country with letters and surrogate speakers opposing the reorganization plan. After all, the White House had officially billed the court-packing plan as "judicial reorganization" legislation, and the network of businessmen, lawyers, and economic conservatives that had galvanized the fight over court-packing saw an opening to allege that Roosevelt was now continuing his efforts to centralize dictatorial powers in the Presidency. ${ }^{n}$

To complicate matters, the extent of the powers the president was requesting combined with the public attacks to prompt political defections even among legislators who were otherwise supportive of the administration. Later we will return to the full range of reasons why legislators had to limit the president's reorganization authority. At this point it is simply worth emphasizing that the opposition was not merely symbolic. Even when the New Deal coalition had been more prominent in the legislature, some of the administration's legislative victories had depended on lodging regulatory power in independent multimember commissions rather than ordinary executive departments. Legislators were plainly concerned about the implications of the reorganization bill for both the recently created and more longstanding

75 Polenberg, Reorganizing Roosevelt's Government at 150-54 (cited in note 22) (describing the public's growing disapproval of the reorganization plan).

76 See generally Jeffrey S. Banks and Joel Sobel, Equilibrium Selection in Signaling Games, 55 Econometrica 647 (1987) (explaining game theoretic accounts of signaling).

77 See Polenberg, Reorganizing Roosevelt's Government at 50-66 (cited in note 23). 
independent regulatory commissions, including the FTC, the Interstate Commerce Commission, the NLRB, and the SEC. ${ }^{78}$

The president eagerly sought to revisit the legislative bargain giving these agencies broad statutory powers but also formal independence and a multimember structure. Roosevelt had by 1938 already made efforts to control these commissions through decisions to fire appointees with fixed terms, but the Supreme Court had thwarted him, finding that Congress could provide for fixed terms that would prevent the president from simply eliminating commissioners who disagreed with him. ${ }^{79}$ How else could the White House get power over these agencies? The reorganization bill would do the trick: the SEC's authority could simply be placed under Treasury or Commerce, where loyal political appointees could reign. Congressional compromises creating new regulatory powers but yoking them to cumbersome structures could easily become undone.

Ever sensitive to interest-group pressures, legislators were also keenly aware that important constituencies ranging from veterans to unions to doctors believed they had something to lose from reorganization. Veterans were concerned that consolidation of the multimember Civil Service Commission would erode the preference for hiring veterans for government jobs. Veterans also feared that the Veterans Administration would be consolidated into the proposed new Department of Welfare, disrupting the client-like relationship that had developed between veterans and their bureau. The NAACP had been angling for the appointment of an African-American to the Civil Service Commission and feared this project would be thwarted by consolidation. ${ }^{81}$ In effect, the opposition to executive reorganization was more than symbolic, and it was dispersed beyond the committed ideological opponents of the New Deal. Doctors sought to continue their dominance of the PHS and-curiously-preferred that it remain lodged deep inside the Treasury Department instead of forming the core of a new cabinet-level Welfare Department. Although senior Treasury officials were unlikely to view the work of the PHS as a priority, the more politically active doctors saw this as an advantage since it allowed organized medical professionals to more easily dominate the work of the bureau.

78 See id at 90-93. See also Committee Set Up on Reorganization, NY Times 10 (Jan 20,1937) (describing the appointment of a special House committee to handle the reorganization plan and summarizing a policy statement by the US Chamber of Commerce expressing concern that independent commissions might cease to be independent if they were placed under executive control).

79 See Humphrey's Executor, 295 US at 629-30.

80 See Polenberg, Reorganizing Roosevelt's Government at 80-81 (cited in note 22).

81 See id at $83-84$.

82 See id at 81-83; Mansfield, 29 Pub Admin Rev at 333-34 (cited in note 10). 
As opposition to the reorganization bill mounted, the White House sought to allay fears that the president would use reorganization to circumvent previous congressional compromises. White House allies supported amendments to the bill excluding some independent regulatory agencies from its coverage, imposing sunsets, and otherwise limiting the scope of the bill. ${ }^{83}$ Nonetheless, by 1938 , the ill-fated executive reorganization project had too many strikes against it. The most vigorous opponents of the New Deal-working through citizens' committees outside the legislature and through conservative Republicans and Southern Democrats within it-tarred the reorganization bill by associating it with the court-packing plan. ${ }^{84}$ Moderate New Deal supporters sensitive to interest group concerns were less inclined to be supportive of the president at a time when his public standing was visibly declining and when reorganization could dilute legislators' own power to structure political compromises through independent commissions. ${ }^{85}$ Moderates who sought to make the bill more amenable politically by making amendments exempting certain agencies or otherwise weakening the bill had to contend with opposition from the committed foes of the New Deal (who often voted strategically against the amendments) and with uncertain reactions from the White House (which occasionally sought to thwart the amendments, hoping to preserve a stronger bill). ${ }^{86}$ And even the more vigorous White House supporters were occasionally miffed by the administration's less-than-adroit responses to criticism, which included sheepish press statements from the president denying any interest in "dictatorial" power and copious refusals to discuss the types of reorganization plans the president would pursue. The bill died. ${ }^{87}$

But the president was undaunted. Choosing to treat the demise of the 1938 bill as a temporary setback, he almost immediately instructed his aides to reopen negotiations on a more limited bill. In sharp contrast to their earlier strategy, White House negotiators now allowed the congressional leadership to take a major role in crafting the bill. ${ }^{88}$ The civic organizations that had opposed reorganization seemed unconcerned about the lower-profile negotiations still unfolding, having declared

83 See Polenberg, Reorganizing Roosevelt's Government at 164-66 (cited in note 22).

84 See Leuchtenburg, Franklin D. Roosevelt and the New Deal at 277 (cited in note 27) (asserting that the organizations that had opposed Roosevelt's court-packing plan "stamped reorganization as yet another attempt ... to subvert democratic institutions").

85 See Polenberg, Reorganizing Roosevelt's Government at 167 (cited in note 22) (describing how some of Roosevelt's supporters in the House voted against the bill because they could not obtain formal exemptions for their "pet agencies").

86 See Leuchtenburg, Franklin D. Roosevelt and the New Deal at 278 (cited in note 27).

87 See id at 277-80 (discussing the fear of Roosevelt's despotism and the eventual death of the 1938 bill).

88 See Polenberg, Reorganizing Roosevelt's Government at 181-88 (cited in note 22). 
victory and perhaps waiting for a different opportunity to weaken the administration. Meanwhile, some Democratic legislators who scuttled the previous plan now supported it. The White House's nominal supporters in the second iteration may have been swayed by changes in the bill itself, which now included a two-house veto provision governing reorganization plans, exempted many independent agencies, and included sunset provisions. ${ }^{89}$ Since most of the president's party still supported the substance of the federal government's new administrative and regulatory functions-even if they differed with the president about the power he should have to reorganize them-some legislators may have also sought to blunt conservative lawmakers' attacks on the allegedly sprawling and disorganized regulatory state that the New Deal had created.

The resulting bill epitomized the exercise in compromise that the late New Deal had become. At long last, Roosevelt had reacquired executive powers over the very architecture of the federal state. He had gained the power to transfer, abolish, or modify existing agencies to reflect his goals, regardless of whether these involved short-term conflicts with congressional conservatives eager to dismember fragile New Deal bureaus or longer-term concerns about the legacy of his signature programs. ${ }^{91}$ He could even abolish entire agencies without transferring their functions, ${ }^{92}$ thereby exercising a sort of line-item veto power bound to increase presidential bargaining leverage, ${ }^{93}$ as long as he returned the unspent appropriations to the Treasury for Congress to control. $^{94}$ The bill's design also contemplated reorganization plans that could result in major layoffs or functional changes in the work of agency employees, thereby freeing up already appropriated resources to hire new officials more likely to be loyal to the White House.

89 See id at 185.

90 See Alfred B. Teton, Reorganization Revisited, 48 Yale L J 573, 583-84 (1939) (detailing how the New Deal-inspired Chandler Act authorized the SEC to intervene in bankruptcy proceedings before a judge and to render advisory opinions on reorganization plans); James N. Rosenberg, Reorganization Yesterday, Today, Tomorrow, 25 Va L Rev 129, 131 (1938) (arguing that federal regulation or reorganization is unsurprising given the growth of state regulation over other areas of the economy).

91 See Reorganization Act of 1939 § 4, 53 Stat at 562; 3 USC § 45a (1946); 31 USC § 2 (1941); 5 USC \$§ 133-133r, 133t (1941).

92 See Reorganization Act of $1939 \S 9,53$ Stat at 563 (requiring that all appropriations not expended when an agency function is abolished be "impounded and returned to the Treasury").

93 Consider Clinton v New York, 524 US 417 (1998) (concluding that the line-item veto unduly and problematically enhanced executive power).

94 See Reorganization Act of $1939 \S 4(d)(3), 53$ Stat at 562.

95 See Reorganization Act of 1939 \$10,53 Stat at 563.

96 The White House would have to argue that the funds for new employees were being expended for the same broad purpose that Congress had already approved through the appropriations process. But the bill's creation of presidential authority to allocate legal powers across 
All of these powers came at a price, however. Deft navigation would be necessary for Roosevelt, the one-time Navy subcabinet official, to use these powers. Serious constraints were built into the new law." The White House had to justify reorganization on the basis of financial savings or efficiency. ${ }^{98}$ It had to report to Congress how much would be saved by each reorganization plan. Virtually all independent agencies except the Social Security Board were off limits, leaving in place statutory deals that had been blessed by the Supreme Court in Humphrey's Executor and that frustrated presidential efforts to control agencies directly. ${ }^{100}$ Roosevelt was specifically barred from creating new cabinet agencies or abolishing existing ones. ${ }^{101}$ No reorganization plan could explicitly change the purpose of appropriations (though who controlled the interpretation of that purpose within agencies could obviously change), shield agencies from existing litigation, preserve agencies that had already been legally subject to termination through statutory action, or create legal authority out of whole cloth for entirely novel government functions not vested in any existing agency (though existing legal authority could be transferred to new entities). ${ }^{102}$ And there was the two-house veto: reorganization plans had no effect until after sixty days had elapsed (during which Congress had to be in session). Before the sixty-day clock had run its course, a simple majority vote in both houses disapproving the reorganization plan invalidated its legal effect. ${ }^{103}$ In short, despite Roosevelt's best efforts to avoid these limitations on his authority, the incremental authority he gained was sufficient to give him room to operate as both a legal and political architect at a critical juncture. He would soon use it.

\footnotetext{
bureaucratic entities (including new ones), coupled with its clear authority to lay off employees, implied some ability to reallocate funds to pay for new officials overseeing the work of newly reorganized bureaus.

97 See Polenberg, Reorganizing Roosevelt's Government at 185 (cited in note 22) (describing how the 1939 Act authorized the president only to suggest plans of reorganization subject to a veto by a majority of both houses and to appoint six administrative assistants); John D. Millett and Lindsay Rogers, The Legislative Veto and the Reorganization Act of 1939, 1 Pub Admin Rev 176, 177-78 (1941) (suggesting that the two-house veto in the 1939 Act strikes a "new balance" between the executive and legislative branches over the organization of federal agencies).

98 Reorganization Act of $1939 \S 1$ (a), 53 Stat at 561 (circumscribing the president's reorganization authority to plans that achieve five efficiency-related purposes).

99 Reorganization Act of 1939 § 4(e), 53 Stat at 562.

100 Reorganization Act of 1939 \& 3(b), 53 Stat at 561.

101 Reorganization Act of 1939 § 3(a), 53 Stat at 561.

102 Reorganization Act of 1939 § 3(d)-(f), 53 Stat at 562.

103 Reorganization Act of $1939 \S 5,53$ Stat at 562-63.
} 
B. Creation of the FSA: "To Strengthen the Arms of Democracy"

Once passage of the Reorganization Act of 1939 appeared imminent, the small group of presidential advisers working on the new executive branch architecture shifted their attention from selling the legislature to finalizing what bureaus would move where. The president took a keen interest in the details of this process. Inside the White House, the president worked with a close-knit group of advisers to set reorganization priorities. The FSA was to be among the first agencies created, with the initial transfers of authority affecting the Social Security Board, Office of Education, Public Health Service, and a number of smaller and temporary New Deal legacy agencies. Only later did the president decree (perhaps wanting to dispel his opponents' concern that he was attempting to replicate the features of the defeated 1938 reorganization bill) that the FSA would be enlarged with the addition of the FDA. ${ }^{105}$

On April 25, 1939 just three weeks after the executive reorganization legislation passed, the White House issued an elaborate public announcement accompanying the first use of the president's authority from the Act. The centerpiece of the announcement was the creation of a noncabinet independent agency under a single administrator to manage health, education, and various aspects of "security" policy. Gone were references to welfare. In its stead, a "Federal Security Agency" was announced, centralizing power over the SSB (an independent agency), the PHS (from Treasury), the Office of Education (from Interior), the US Employment Service (from Labor), and relief programs including the National Youth Administration (from the Works Progress Administration) and the Civilian Conservation Corps (another independent agency). ${ }^{106}$ In keeping with the president's wishes, the transfer of the FDA (from Agriculture) was not announced but followed in 1940

104 Roosevelt, Message of the President at 246 (cited in note 4) ("These measures have all had only one supreme purpose - to make democracy work - to strengthen the arms of democracy in peace or war and to ensure the solid blessings of free government to our people in increasing measure.").

105 The procession of bureaus and functions added to the agency is described in the organizational charts the FSA prepared for congressional staff. See Federal Security Agency, Organizational Charts and Budgets, FY 1952 (1952), available at National Archives, Organizational Charts, Federal Security Agency, Entry 9, Box 2 (chronicling the development of the FSA and prominently emphasizing its wartime activities).

106 See Miles, The Department of Health, Education, and Welfare at 19 (cited in note 13) (discussing use of the term "security" and how it was considered more acceptable to Vice President John Garner, and noting that it foreshadowed key structural decisions that affected the trajectory of the agency as a result of its involvement in defense-related pursuits). Regarding the structure of the agency itself, see Bureau of Public Inquiries, Office of War Information, United States Government Manual, Fall 1942581 (GPO 1942). With respect to the reorganization, see Roosevelt, Message of the President at 251-54 (cited in note 5). 
in accordance with the administration's secret plans. ${ }^{107}$ To run the FSA, the president recruited the ambitious Paul McNutt, a former law professor and governor of Indiana who was then completing a tour as the American colonial czar in charge of the Philippines.

It is telling that Roosevelt chose to feature "security" so prominently in the agency's name. While the term was broadly identified with pensions and unemployment benefits at the time, "security" was also a fertile domain for legal and policy entrepreneurship. Even a halfdecade before the creation of the FSA, Roosevelt was already referring to "security" in relation to the administration's crime control initiatives, a domain of sharp, and not entirely uncontroversial, federal expansion and policy entrepreneurship during the early New Deal. ${ }^{110} \mathrm{He}$ underscored security as a defining goal for a host of federal regulatory policies. "Early references to "security" policy in the Roosevelt administration also occasionally encompassed geostrategic national defense. Indeed, a survey of Roosevelt's public statements during his second term (the presidential term in which the FSA was created) reveal nearly as many references to "security" that do not concern pensions or unemployment benefits as those that do concern to such programs. ${ }^{112}$ The administration's description of its goals, moreover, appeared to reflect not only an exercise in public rhetoric but a politically significant willingness to reshape the federal bureaucracy and yoke bureaus together under a new set of legal parameters.

It is also telling that Roosevelt so vigorously prioritized bureaucratic changes in his lawmaking agenda. Aside from expanding the Executive Office of the President itself, the creation of the FSA was Roo-

107 See Proposed Interdepartmental Transfers (by department) (Apr 14, 1939), available at Franklin D. Roosevelt Presidential Library, President's Committee on Administrative Management, Correspondence and Papers, Reorganization (1939), folder on Interdepartmental Transfers, Box 24 (summarizing efforts to transfer the Food and Drug Administration and noting responses).

108 Regarding McNutt's appointment, see I. George Blake, Paul V. McNutt: Portrait of a Hoosier Statesman 227-28 (Central 1966).

109 See, for example, Miles, The Department of Health, Education, and Welfare at 18-19 (cited in note 13).

110 See Mariano-Florentino Cuéllar, Book Review, The Political Economies of Criminal Justice, 75 U Chi L Rev 941, 960 (2008) (discussing Roosevelt's determination to forge crime control into a politically salient issue), reviewing Jonathan Simon, Governing through Crime: How the War on Crime Transformed American Democracy and Created a Culture of Fear (Oxford 2007).

111 For example, in 1937 Roosevelt routinely made references to "security of property and the maintenance of order," "economic security," and "work security" as well as "international security," and the "security of the nation." Roosevelt discussed security in the ensuing years in the context of economic policy, crime control, and national defense. See The American Presidency Project, Results of Keyword Search for "Security" between 1937 and 1945, online at http://www.presidency.ucsb. edu/ws/index.php (visited Apr 14, 2009).

112 See id. 
sevelt's most immediate political priority. ${ }^{113}$ Though in some respects the administration already appears to have had a plan that resulted in the merger of agencies within FSA, the political and legal context was also beginning to have some effect in how the plan was being crafted. The new reorganization law required a focus on thrift and efficiency, so Roosevelt's aides made at least a symbolic effort to play this up in their justification for the reorganization plan. But the other contextual factor shaping the reorganization foreshadowed one of Roosevelt's distinctive political innovations. In 1939 the possibility of a war that might affect the United States was no longer remote, even if the administration itself had yet to settle on a course for managing the associated foreign policy problems. Growing public concerns about national defense were also echoed in the legislature, where conservative Democrats and Republicans (even isolationist ones) often tended to support national defense-related activities. ${ }^{114}$ In light of this, Roosevelt's plan emphasized the potential benefits to national security of creating a single agency to focus on health and economic security that could be more easily managed and more easily deployed to strengthen national defense. ${ }^{115}$ As the president's reorganization message emphasized:

In these days of ruthless attempts to destroy democratic government, it is boldly asserted that democracies must always be weak in order to be democratic at all; and that, therefore, it will be easy to crush all free states out of existence.... We are not free if our administration is weak. But we are free if we know, and others know, that we are strong; that we can be tough as well as tender-hearted; and that what the American people decide to do can and will be done, capably and effectively, with the best national equipment that modern organizing ability can supply in a country where management and organization is so well understood in private affairs. ${ }^{116}$

If promoting the national defense in the face of external threats was the goal Roosevelt emphasized in the reorganization message, "efficiency" and accountability were to be the publicly asserted means of achieving that goal. Indeed, the president's effort to justify and create

113 See Polenberg, Reorganizing Roosevelt's Government at 6 (cited in note 22). 1972).

114 See Richard Polenberg, War and Society: The United States, 1941-1945 76-77 (Lippincott

115 See Waldo Heinrichs, Threshold of War: Franklin D. Roosevelt and American Entry into World War II 3-12 (Oxford 1988) (indicating growing public concern about national defense, and a willingness of at least some otherwise conservative members of the legislature to support defense-related activities). With respect to the use of the term "security," see Miles, The Department of Health, Education, and Welfare at 19 (cited in note 13).

116 Roosevelt, Message of the President at 245-46 (cited in note 4) (introducing the reorganization plan to Congress). 
the FSA was inextricably bound up with the fight to pass a reorganization bill. Once the reorganization bill finally passed, it forced the president to submit plans to Congress for approval. As a matter of statutory formalism, the primary goal of the plans, moreover, had to be cost savings. ${ }^{117}$ Accordingly, much of Roosevelt's initial justification for the FSA focused on the potential savings and fiscal efficiency that could be achieved by consolidating agencies with conceptually related functions. This is amply borne out in the president's reorganization statement. Nonetheless, that statement deftly links the "economy" argument with two other ideas that are presented as being intimately connected to cost: the first is an "efficiency" rationale that essentially amounts to a thinly disguised justification for presidential control; the second is an assertion that the national security capacities of the United States depended on an effectively organized government. This latter point in the reorganization message is developed by reference to repressive dictatorships (presumably an allusion to Hitler) and resonates with the repeated efforts made almost immediately after the FSA's creation to emphasize its role in the war effort. ${ }^{11}$

The agency's creation received considerable media attention. Although some newspaper coverage in fact emphasized the efficiencies that the agency merger would allegedly create, much of it discussed the merger in the larger context of the previous year's battle over reorganization. ${ }^{119}$ This connection highlights how the reorganization process was understood to involve political stakes that would affect the relationship between the president and core regulatory and administrative functions of government. Indeed, at times the newspaper coverage acknowledged-in part because of Roosevelt's own rhetoric about the reorganization - that the changes would enhance the president's ability to control bureaucratic functions more directly. ${ }^{120}$ Other observers,

117 Reorganization Act of 1939 § 1(a), 53 Stat at 561.

118 See Polenberg, Reorganizing Roosevelt's Government at 194-95 (cited in note 22) (discussing FDR's view that there is a strong relation between weak governments and dictatorships). See also Belair, President Decrees Three Big Offices in Centralizing 21, NY Times at 1 (cited in note 22) (characterizing Roosevelt's message regarding the reorganization plan as "[a]pparently anticipating" scheduled remarks by Hitler).

119 See Belair, President Decrees Three Big Offices in Centralizing 21, NY Times at 1 (cited in note 22) (describing how Congress voiced little opposition to Roosevelt's plan, in part because certain parts had been "so thoroughly discounted ... and so well established" that little reason remained to engage in a public fight).

120 See, for example, Chesly Manly, President Puts U.S. Agencies in 3 Supergroups: Makes First Transfer of Reorganization, Chi Daily Trib 2 (Apr 26, 1939) (diagramming the divisions and agencies, "some of them previously independent," that Roosevelt planned to make "responsible only to him"). The news coverage of the FSA's creation combined with the fact that polling organizations at the time were asking the public about the agency also indicates the relative degree of attention levied on the president's structural choices at the time. 
including the consistently anti-Roosevelt Chicago Daily Tribune, tried to forge a rhetorical boomerang by turning the president's own allusions to external threats against his reorganization plan:

A Nazi or Fascist could look at the three new agencies and their component parts and find something very familiar in them. This is the story of a totalitarian state. These authorities, administrations, and corporations now rearranged for more direct control by the chief executive are agencies by which the government pursues its program of mobilizing national activities under what the Germans call the Fuehrer. ${ }^{12}$

Despite such lingering opposition in some quarters and the previous year's spirited fight over reorganization, the president allayed many of his critics. The centralizing structure of the FSA was decidedly incremental. It did not include the Veterans Administration, prisons, or responsibility for government employee pensions. Moderate legislators who had earlier opposed the reorganization were more inclined to support it. The agency was not cabinet level, giving those legislators further control over this dimension of reorganization in the future. And by consolidating disparate bureaus, the White House blunted Republicans' and Southern Democrats' arguments about the sprawling proliferation of smaller agencies. Bureaucrats occasionally offered spirited resistance. Sounding a note of alarm at the prospect of combining employment placement and social insurance services, the Labor Department all but predicted the collapse of the economy if its US Employment Service was consolidated with the SSB under the FSA:

We are opposed to the proposed transference of the U.S. Employment Service to the Social Security Board on the following grounds .... An insurance dominated employment service would almost certainly lead to neglect of aggressive placement activities, which in turn would lead to increased demands upon insurance benefits. The net result? A static, dying economic order. ${ }^{12}$

Most officials, however, quickly fell into line. Some, particularly FDA officials who had chafed under an unsympathetic Agriculture Department, were quite favorably inclined to the move. Nor did the president, generally skilled at quelling internal administration dissent, run

121 Editorial, Our Autocratic State, Chi Daily Trib 15 (Apr 27, 1939).

122 US Department of Labor, Memorandum on Proposal to Transfer the US Employment Service to the Social Security Board (1939), available at Franklin D. Roosevelt Presidential Library, Correspondence and Papers of the President's Committee on Administrative Management, Correspondence and Papers: Reorganization, Reorganization Plan I Folder, Box 24 (emphasis added) (establishing how agency opposition to reorganization created a nontrivial political cost). 
into much opposition in his own administration. Though Harold Ickes's Interior Department was a "loser" in the reorganization process, the president considered the effort a priority, and even Ickes ultimately cooperated.

The combination of the intense battle over reorganization and the newspaper coverage about the creation of the agency itself suggests that a substantial proportion of the nation's elites and its politically engaged public were aware of the FSA's creation. ${ }^{124}$ Polls taken not long after the creation suggest that Roosevelt's action met with considerable support, either because it was perceived as advancing the relatively anodyne efficiency goals he sought to emphasize (thrift appealed even to moderate Republicans) or because some constituents supported the health and public benefit programs that the FSA would administer and correctly perceived that the move would bode well for the political future of these programs. The most vociferous opponents were Republicans and a smattering of Southern Democrats who by this point were emphatically opposed to the president's agenda. These anti-Roosevelt partisans also repeatedly noted that the creation of the FSA was probably a move to make permanent a number of allegedly temporary programs. ${ }^{125}$ Over time this proved to be partly true and partly false, but far more complex currents were at work within the agency-and these help explain why its functions continue to play such a prominent role today.

123 See Miles, The Department of Health, Education, and Welfare at 18-21 (cited in note 13); Polenberg, Reorganizing Roosevelt's Government at 188 (cited in note 22).

124 For an example of press opposition, see Editorial, Our Autocratic State, Chi Daily Trib at 15 (cited in note 121).

125 Manly, President Puts U.S. Agencies in 3 Supergroups, Chi Daily Trib at 2 (cited in note 120) (relaying objections to Roosevelt's plan by Rep John Taber, ranking minority member of the House Appropriations Committee). 
TABLE 1

SELECTED BUREAUS TRANSFERRED TO THE FSA BY 1940

\begin{tabular}{|c|c|c|c|}
\hline Bureau & Budget (1940) & Previous Status & Key Functions (1940) \\
\hline $\begin{array}{l}\text { Social Security } \\
\text { Board }\end{array}$ & $\$ 368,000,000$ & $\begin{array}{l}\text { Independent } \\
\text { Commission }\end{array}$ & $\begin{array}{l}\text { Administering social } \\
\text { insurance payments for } \\
\text { older Americans; providing } \\
\text { grants for states to develop } \\
\text { pension and unemployment } \\
\text { insurance schemes }\end{array}$ \\
\hline $\begin{array}{l}\text { Office of } \\
\text { Education }\end{array}$ & $\$ 19,100,000$ & $\begin{array}{l}\text { Bureau of } \\
\text { the Interior } \\
\text { Department }\end{array}$ & $\begin{array}{l}\text { Allocating education } \\
\text { assistance grants to states; } \\
\text { developing vocational } \\
\text { education programs; } \\
\text { conducting and funding } \\
\text { education-related research }\end{array}$ \\
\hline $\begin{array}{l}\text { US Employment } \\
\text { Service }\end{array}$ & $\$ 6,700,000$ & $\begin{array}{l}\text { Bureau of } \\
\text { the Labor } \\
\text { Department }\end{array}$ & $\begin{array}{l}\text { Providing employment } \\
\text { placement and } \\
\text { training services }\end{array}$ \\
\hline $\begin{array}{l}\text { Food and Drug } \\
\text { Administration }\end{array}$ & $\$ 2,700,000$ & $\begin{array}{l}\text { Bureau of } \\
\text { the Agriculture } \\
\text { Department }\end{array}$ & $\begin{array}{l}\text { Ensuring the safety of most } \\
\text { food products; regulating } \\
\text { the pharmaceutical and } \\
\text { cosmetics industries }\end{array}$ \\
\hline $\begin{array}{l}\text { Public Health } \\
\text { Service }\end{array}$ & $\$ 29,200,000$ & $\begin{array}{l}\text { Bureau of } \\
\text { the Treasury } \\
\text { Department }\end{array}$ & $\begin{array}{l}\text { Conducting health research; } \\
\text { providing public health } \\
\text { services to combat infectious } \\
\text { diseases; providing health } \\
\text { services to communities that } \\
\text { were economically margina- } \\
\text { lized (especially in rural } \\
\text { areas) or affected by disas- } \\
\text { ters; administering health- } \\
\text { related grants to states }\end{array}$ \\
\hline
\end{tabular}

Source: Division of Public Inquiries, Office of War Information, United States Government Manual, Winter 1943-1944 423-43 (GPO 1943); Federal Security Agency, Organizational Charts and Budgets, FY 1952 (cited in note 105).

\section{Overview of Evolution and Growth}

Although the decade or so that followed the creation of the FSA was indeed a time of "considerable shifting," consistency also characterized the basic structure of the agency, including the existence of four core agencies - the FDA, the SSB, the PHS, and Office of Educationthat accounted for the lion's share of the FSA's budget and regulatory 
responsibilities. ${ }^{126}$ Some explicitly war-related functions, most notably the biological weapons-focused War Research Service and the Office of Community War Services, were eventually transferred or abolished. ${ }^{127}$ Changes also affected employment-related functions, some of which were abolished or eventually transferred to Labor. Finally, President Truman centralized control over social security in 1947 by abolishing the SSB altogether and transferring its functions to the FSA administrator.

The overall trajectory of the FSA during and after the war was one of sharp expansion. Most FSA bureaus experienced marked budget increases, growing administrative responsibilities, and continuity of their organizational lease on life. ${ }^{129}$ The National Institutes of Health (NIH) (at the time known as the "National Institute of Health") - a component of the PHS - acquired new funds and responsibilities for national defense-related research. ${ }^{130}$ The SSB covered agricultural workers and domestic workers. The resources funneled to state education programs through the FSA's Office of Education skyrocketed. ${ }^{i 31}$ In contrast, the Federal Loan Agency and Federal Works Agency - the other two "superagencies" created when the FSA was forged-soon suffered declines in funding and were both eventually abolished. ${ }^{132}$

126 See Office of Government Reports, United States Government Manual, October $1939224-45$ (GPO 1939); Office of Government Reports, US Information Service, United States Government Manual, Fall 1940547 (GPO 1940); Office of Government Reports, United States Government Manual, September 1941 at 614 (cited in note 20); Bureau of Public Inquiries, United States Government Manual, Fall 1942 at 581 (cited in note 106); Division of Public Inquiries, United States Government Manual, Winter 1943-1944 at 420-21 (cited in table 1); Division of Public Inquiries, Government Information Service, Bureau of the Budget, United States Government Manual, 1945 417-19 (GPO 2d ed 1945); Federal Security Agency, First Annual Report of the Federal Security Administrator 1-3 (1940); Federal Security Agency, Second Annual Report 2-3 (1941); Federal Security Agency, Annual Reports, For the Fiscal Years 1941-1942, 1942-1943 v-vi (GPO 1943); Federal Security Agency, Annual Report, For the Fiscal Year 1944 iii (GPO 1944).

127 See Division of Public Inquiries, Government Information Service, Bureau of the Budget, United States Government Manual, 1946585 (GPO 1st ed 1946); Federal Security Agency, Annual Report, For the Fiscal Year 1945 518-21 (GPO 1945).

128 See Miles, The Department of Health, Education, and Welfare at 22 (cited in note 14) (discussing how this change was in keeping with the original recommendations of the Brownlow Committee).

129 Regarding changes in the responsibilities of FSA units, see, for example, James Robert Dean, $\mathrm{Jr}$, FDA at War: Securing the Food that Secured Victory, 53 Food \& Drug L J 453, 472-74 (1998).

130 See Donald Swain, The Rise of a Research Empire: NIH, 1930 to 1950, Science 1233, 1234-36 (Dec 14, 1962) (discussing how the National Institute of Health increased its budget from $\$ 707,000$ in 1940 to more than $\$ 60$ million in 1951).

131 See Miles, The Department of Health, Education, and Welfare at 21-24 (cited in note 13) (summarizing the expansion of the Office of Education's responsibilities and later Truman's reorganization plan for the FSA).

132 Regarding dissolved agencies, see Office of the Federal Register, United States Government Manual 2001-2002 596-652 (2001). See also Agency Absorbs 8 Bureaus but Boosts Payroll, Chi Daily Trib 11 (Sept 10,1949) (describing the transfer of agencies from the abolished Federal Works Agency to the new General Services Agency); W.H. Lawrence, President Merges Housing Agencies, NY Times 24 (Feb 25, 1942) (discussing Roosevelt's abolition of the Federal Loan Agency and the transfer of its functions to a National Housing Agency and to the Commerce Department); 
Some of the changes occurring during the war years can be appreciated in the budgets of the FSA's four major administrative and policymaking bureaus. As the figures below indicate, the FDA managed to retain its budget even during the war years. Both the Public Health Service and the Office of Education experienced dramatic increases during the war years, with the Public Health Service increases coming later and becoming more permanent than those seen by the Office of Education. Growth in appropriations for the sprawling social security apparatus-including grants for states to establish social insurance systems - continued to increase during much of the war, even while many other domestic agencies were forced to accept flat or declining budgets. Increases became even more pronounced for the Public Health Service and the Office of Education in the postwar period."

FIGURE 1

SELECTED FSA BUREAU APPROPRIATIONS:
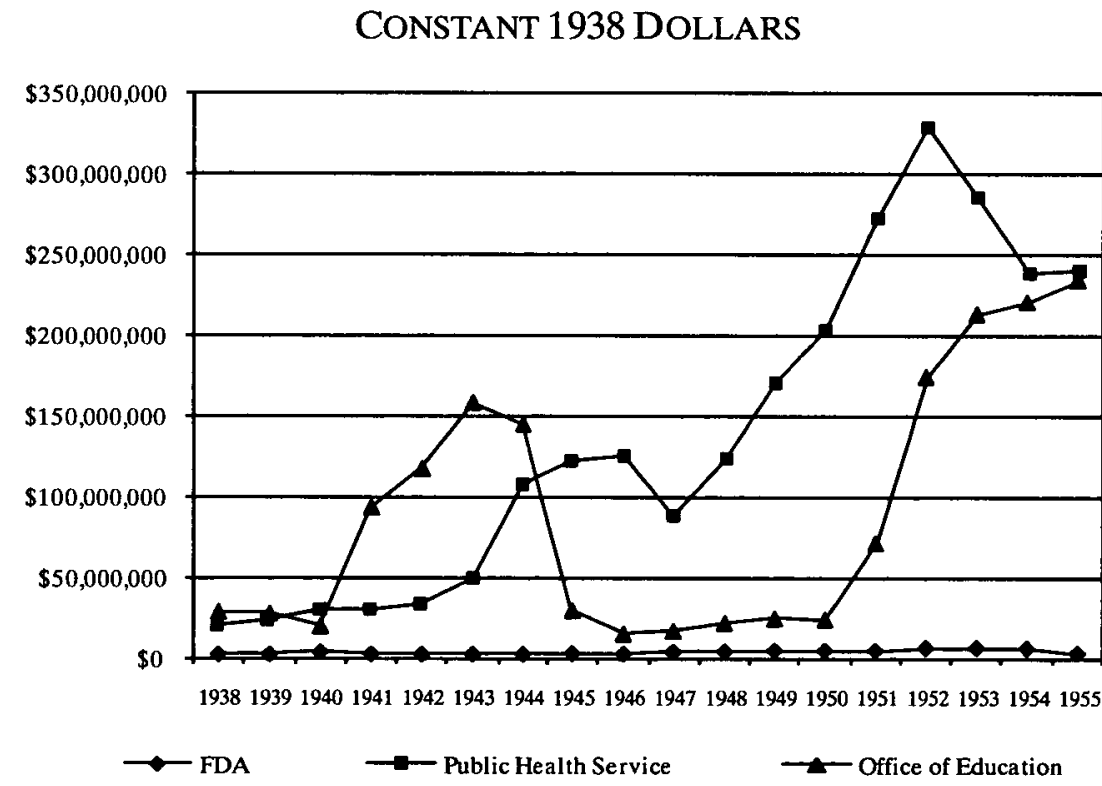

Polenberg, Reorganizing Roosevelt's Government at 187 (cited in note 22) (referring to a Roosevelt administrative associate who wanted the reorganization plan to be "extensive and sweeping"). Regarding the legislature's role, see William Morrow, Congressional Committees 14-35 (Charles Scribner's Sons 1969). Regarding organized interests, see Polenberg, War and Society at 91-92 (cited in note 114); Francis, President's Influence Is Slipping As Solons Labor, LA Times at A5 (cited in note 27).

133 See US Census Bureau, Statistical Abstract of the United States 495 table 776 (GPO 119th ed 1999). Agency figures were obtained from the 1935 through 1955 editions of the annual Budget of the United States. 
Beginning in 1947 President Truman sought to use the recently renewed presidential reorganization authority to elevate the agency to cabinet status. Truman's move may have had some symbolic purposes, but it was bound up with more practical political considerations. For one, Truman decided to make a major push to achieve national health insurance. ${ }^{14} \mathrm{He}$ may have believed the plan would be furthered by elevating its primary proponent-FSA Administrator Oscar Ewing-to cabinet status. ${ }^{135}$ Doing so would have generated additional (and, assuming the plan to elevate the agency to cabinet status succeeded, probably favorable) news coverage and would have enhanced perceptions that the necessary federal administrative structure to administer national health insurance was already in place. ${ }^{1.6}$ For another, the structural impact of turning an independent agency into a cabinet agency could be significant. In effect, doing so would have added yet another layer of political appointees (three assistant secretaries) to the mix of senior FSA officials, further increasing the administration's ability to direct how food and drug regulations were administered (something that the first HEW Secretary, Oveta Hobby of the Eisenhower administration, soon realized would absorb a considerable amount of her time and effort), how benefit payments were issued, and how the agency's myriad other functions were carried out. ${ }^{137}$ Despite the fact that Truman retained reorganization authority much like Roosevelt's, his efforts to elevate the FSA were thwarted by a legislative veto-the only such veto of one of his reorganization plans. ${ }^{138}$

134 See Miles, The Department of Health, Education, and Welfare at 23 (cited in note 13).

135 See id at 23 (noting that as a result of Truman's "ill-starred effort," Ewing became the "chief scapegoat" for vocal critics of the national health insurance plan).

136 See id at 28-29 (describing how Eisenhower's successful transformation of the FSA into the cabinet-level Department of Health, Education, and Welfare brought about this exact media effect).

137 See id at 30 (detailing how the supposedly low-level regulatory responsibilities of HEW, the successor to the FSA, ended up occupying the attention of the Department Secretary).

138 See Miles, The Department of Health, Education, and Welfare at 23-24 (cited in note 13) (identifying opposition to national health insurance as the reason why Truman was not able to elevate the FSA to cabinet status); Jay Walz, Welfare Agency Has Grown Fast, NY Times E7 (Mar 1, 1953) (reporting that Truman's proposal to elevate the FSA to cabinet status drew criticism from those who feared "the infiltration of politics" into medicine and education). 
FIGURE 2

SOCIAL SECURITY EXPENDITURES:

CONSTANT 1938 DOLLARS

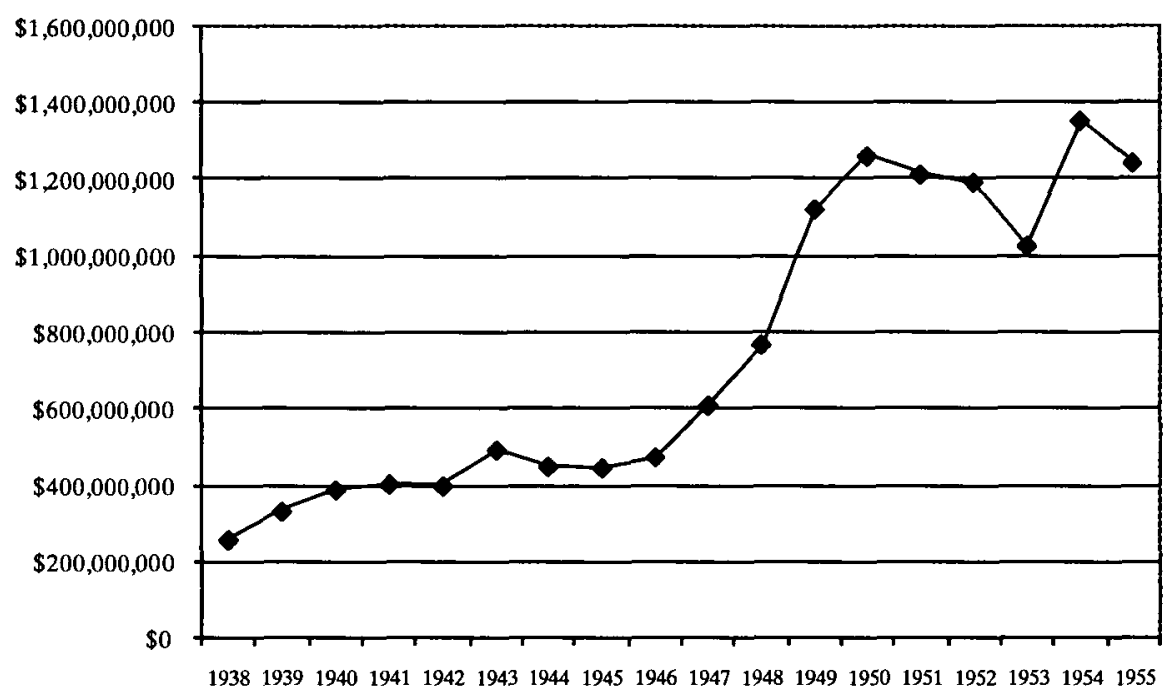

Where Truman failed, President Eisenhower eventually succeeded. Shortly after his inauguration, he submitted a reorganization plan that sailed through congressional review and, by the middle of 1953 , transformed the FSA into HEW. ${ }^{139}$ In the process, the FSA again garnered considerable media attention, some of it - as with the newspaper article quoted below-chronicling the agency's staggering growth during and after the war years:

The reception in political and professional circles accorded new Administration proposals to raise the Federal Security Agency to Cabinet status indicates the great importance that has come to be attached to Federal welfare activities.

The agency that would, thus, attain full and responsible membership in the Administration family is one of the youngest in the Government. It mushroomed out of the New and Fair Deal eras. Moreover, in its days of fabulous growth, since its birth in 1939, it has embraced a number of old-line offices.

The organization of 38,000 employees ... collects and disburses billions of dollars in old age and survivors insurance. And it also enforces the Federal pure food and drug laws. It builds hospitals and 
operates research laboratories. It runs an institution for the mentally ill, and funnels public funds for a printing house to the blind. ${ }^{140}$

Even more dramatic than changes in the agency as a whole were the evolving capacities of specific bureaus, perhaps most notably at the Public Health Service:

[The Public Health Service,] which came into the agency in 1939 with 6,200 employees and an annual appropriation of $\$ 24,692,000$, has experienced phenomenal growth, even in a fast-expanding agency. Public Health today has a personnel of 15,170 and for 1953 has an appropriation of $\$ 283,452,000$. It makes grants for hospitals ( $\$ 134,700,000$ this year), maintains laboratories, and directs such important research organizations as the National Cancer Institute and the National Health Institute. ${ }^{\text {th }}$

As with Roosevelt's own reorganization plan of 1938, the transformation of FSA into a cabinet-level department proved to be something of a battle, which was given a measure of coverage in national newspapers. Truman's effort to create a cabinet-level security and welfare department failed initially amid opposition in the Republican-controlled Congress. ${ }^{142}$ Part of the reason is likely to have been divided government. As David Lewis later speculates in his study of the politics of agency design, in periods of divided government, the legislature is skeptical of supporting a president's reorganization efforts. ${ }^{13}$ Elevating the FSA at the time was particularly troubling because of its health-related functions and the identification of its administrator, Oscar Ewing, with efforts to achieve national health insurance-a goal that was particularly offensive to the congressional Republican leadership. ${ }^{14}$

Illustrating again how a president could deploy the structure of the FSA in the service of a legislative agenda, Truman ordered Ewing to deploy "all the resources within the FSA for vigorous and united action toward achieving public understanding of the need for a national health

140 See Walz, Welfare Agency Has Grown Fast, NY Times at E7 (cited in note 138) (emphasis added).

141 Id. Inflation-adjusted figures confirm the staggering growth at PHS, as do more scholarly accounts of the growth of the agency's research capacity through the creation of the National Cancer Institute and the modern National Institutes of Health. See, for example, Swain, Science at 1236 (cited in note 130).

142 Rufus Miles, Truman Undecided, May Again Ask Agency Bill, LA Times 18 (Aug 19, 1949) (reporting that a coalition of Republicans and Southern Democrats handed Truman "one of his severest setbacks of the session" when they disapproved of his plan to create a cabinet-level agency).

143 Lewis, Presidents and the Politics of Agency Design at 123-27 (cited in note 22) (providing empirical research to support his claim).

144 See Miles, The Department of Health, Education, and Welfare at 168 (cited in note 13). 
program." ${ }^{145}$ The newspapers covered this. ${ }^{145}$ They also covered Eisenhower's efforts to elevate the Department in 1953-one of his first substantive actions as president - which was achieved with relatively little opposition. ${ }^{147}$

Between the end of the Roosevelt years and the agency's bestowal of cabinet status early in the Eisenhower administration, the FSA lived through the eventful years of the Truman administration. During this critical period, the FSA navigated a transition through a postwar political and budgetary environment. Its staff played a major role in President Truman's "Fair Deal." ${ }^{\text {,48 }}$ And FSA Administrator Oscar Ewing, an ambitious New York lawyer eager to raise his profile, continued to promote the idea that security-related laws and policies should encompass both defense-related and domestic risk-reduction initiatives. ${ }^{199}$ Each of these developments appears to have left its mark on the organization.

Although funding for some wartime education- and health-related programs dried up, the agency found itself awash in appropriations for health research and public health initiatives. Wartime programs in this domain appeared to whet congressional appetites for a large health research infrastructure. ${ }^{150}$ Social Security benefits payments also rose as wartime financing constraints began to ebb. As the agency grew, the White House forged a domestic agenda - Truman's "Fair Deal" - that involved further expansion of the FSA programs to include national health insurance and bestowal of cabinet status. ${ }^{131}$

The FSA also began playing a more explicit role in civil defense during the Truman years. Civil defense and security functions lay dor-

145 Jill Quadagno, One Nation, Uninsured 30 (Oxford 2005).

146 See, for example, Truman Seeks Rise in Nation's Health, NY Times 21 (Jan 31, 1948) (describing Truman's request that Ewing study "feasible goals" to improve the health of Americans).

147 See, for example, Anthony Leviero, Eisenhower Offers Plan to Give FSA Status in Cabinet, NY Times 1 (Mar 13, 1953).

148 Consider President Harry S. Truman, State of the Union Address 6 (Jan 5, 1949), online at http://www.presidency.ucsb.edu/ws/index.php?pid=13293 (visited Apr 14, 2009) ("Our domestic programs are the foundation of our foreign policy. The world today looks to us for leadership because we have so largely realized, within our borders, those benefits of democracy for which most of the peoples of the world are yearning.").

149 See generally J.R. Fuchs, Oral History Interview with Oscar R. Ewing, Harry S. Truman Library (May 1, 1969), online at http://www.trumanlibrary.org/oralhist/ewing3.htm (visited Apr 14, 2009).

150 See Swain, Science at 1235-36 (cited in note 130) (discussing the expansion of the National Institutes of Health in the postwar years).

151 See Fuchs, Oral History Interview with Oscar R. Ewing at *6-27 (cited in note 149) (providing a behind-the-scenes look at Truman's abortive attempt to create a national health insurance program). See also Quadagno, One Nation, Uninsured at 27 (cited in note 145) (explaining that health care was a special concern of Truman's because, "[a]s a county judge, Truman had 'been troubled by seeing so many sick people unable to get the care they need ... because they had no money"'), quoting Harry S. Truman, 2 Memoirs: Years of Trial and Hope 19 (Doubleday 1956). 
mant in the United States for most of the period between the end of World War I and the beginning of World War II. Roosevelt formally convened efforts at civil preparedness within the White House in 1940 as American participation in the spreading conflict in Europe and Asia was becoming more likely. ${ }^{152}$ Those functions remained lodged in the White House for much of the war. Although the initial interagency group that focused on civil defense did not specifically include the FSA, the FSA's history is in fact connected to civil defense activities in a number of ways. First, Roosevelt's creation of the FSA emphasized the need for preparedness and held up the agency as an example of it. In that statement and in subsequent speeches, the administration emphasized the link between domestic regulatory and welfare functions and national defense (both before and during the war itself). Second, the White House was in fact drawing on the new superagency for a number of functions related to civil defense preparedness, including draftrelated planning and the use of SSB resources for placing workers in defense-related industries. ${ }^{1.3}$ Later, during the war itself, Roosevelt gave the FSA head a major role in overseeing certain manpower-related preparedness functions. ${ }^{134}$ Third, despite the reluctance of civil defense head Fiorello LaGuardia (concurrently also serving as mayor of New York City) to focus on "sissy stuff," the formal civil defense preparedness effort was eventually forced to shift attention to the public health, education, and welfare aspects of civil defense. These pursuits related directly to the role the FSA was expected to play in emergencies. ${ }^{156}$

152 See Thomas J. Kerr, Civil Defense in the U.S.: Bandaid for a Holocaust? 13 (Westview 1983) (suggesting that the isolationist sentiment that led Americans to ignore civil defense during the interwar period began to recede with the outbreak of war in Europe and the May 1940 proclamation of a state of emergency).

153 See Federal Security Agency, First Annual Report of the Federal Security Administrator at 7-8 (cited in note 126) (highlighting the FSA's major defense programs: (1) selection and placement of defense workers and (2) vocational training for defense workers).

154 See Federal Security Agency, Annual Report, For the Fiscal Year 1944 at ix (cited in note 126) (estimating that 1.5 million professional and technical workers were enrolled in college-level training for war industries, which was "particularly significant [ ] in view of the rapidly developing advances in mechanized warfare").

155 Kerr, Civil Defense in the U.S at 17 (cited in note 152) (explaining how LaGuardia placed a major emphasis on the "protection aspects" of civil defense and downplayed programs such as physical fitness, welfare, nutrition, child care, housing, and consumer advice).

156 See National Security Resources Board, Materials for Use in NSRB Program Development: Preliminary Draft (Nov 25, 1949), available at Harry S. Truman Presidential Library, White House Confidential Files, National Security Resources Board, 3 of 10, Box 27 (identifying the general orders that provided the NSRB with its authority). The FSA and its bureaus are mentioned twenty-one times as integral to national defense-related functions. Some of its key roles include: providing inventory of health manpower resources, providing estimates of wartime needs for health manpower, planning for the distribution and safety of food during wartime, administering a communicable disease control program, and assessing health needs following civilian wartime disasters. 
Ewing did not consider civil defense to be the only security priority within his mandate. When Ewing became one of the administration's point men on national health insurance, he encountered an environment of intense social cleavages and political disagreements about domestic policy. ${ }^{157}$ At least some of these tensions were tangled up with anxiety about the spread of communism and socialism. ${ }^{158}$ While the American Medical Association (AMA) relentlessly sought to link national health insurance to socialism, ${ }^{159}$ Ewing sought to respond with an even more pointed version of the Roosevelt-era penchant for melding domestic risk reduction and geostrategic national defense concerns into a single, overarching appeal to the value of security. Writing in the auspiciously named American Magazine in 1949, Ewing celebrated the value of expanding FSA programs by deliberately framing security concerns in a manner that could apply interchangeably to risk regulation and national defense. "[S]ecurity measures," Ewing opined, "[are] simply an orderly way to take care of ourselves in times of distress-as well as keep us well-with everyone sharing the burden., ${ }^{160} \mathrm{He}$ continued:

Just how secure are you at this moment? If, tomorrow, you have an acute attack ... could you foot the bill ... ? If a child is born in your family, are you secure in the knowledge that he will receive the best attention the medical profession can offer-that he can have the education he may set his heart upon, perhaps a college degree? Suppose you lose your job, or become disabled. What sort of world would lie ahead for you? These personal matters of security are the direct concern of your Federal Security Agency, of which I happen to be the Administrator... . As I see it, security means a sure knowledge that we shall not want for the basic necessities of life, no matter what Fate may have in store .... With that sure knowledge, we can proceed to go about getting the things we want from life under the American system of free choice. ${ }^{161}$

"Free choice," Ewing's philosophy here implied, depended at least as much on remedying potential market failures as it did on allowing consumers to feel that they were making ostensibly unconstrained

157 See Monte M. Poen, Harry S. Truman versus the Medical Lobby: The Genesis of Medicare 140-41 (Missouri 1979) (discussing how the creation of the National Health Service in Great Britain and Truman's push for a national health insurance plan domestically led to unprecedented public interest in national health insurance, including critical coverage by newsweeklies and radio talk shows).

158 See id at $141 \mathrm{n} 2$ (listing articles linking Truman's plan to "socialized medicine").

159 See id at $140-41,148$.

160 Oscar R. Ewing, More Security for You, Am Mag 1, 2 (Jan 1949), available at Harry S. Truman Presidential Library, Papers of Oscar R. Ewing, Federal Security Agency, Speeches and Articles, 1948-1949, Box 38.

161 Id at 1 (emphasis added). 
choices: "When ... an American buys a can of food from a grocery-store shelf, he is so sure that the food is healthful, and that the contents are according to the label, he scarcely thinks about it. I call this real securi$t y$." ${ }^{162}$ From these theoretical foundations, Ewing then offered an explicit response-again mixing geostrategic national defense concerns and risk-reduction rationales - to the AMA's charges about how the FSA was placing the United States on the road toward socialism:

Some people will tell you that these advances for the good of the general welfare are approaches toward Communism. The exact opposite is true. Security is the best defense we have against Communism. When a man is provided through democratic government with the basic securities which make it possible for him to get what he wants, to stand on his own two feet, independently, he will not listen to wild isms. ${ }^{163}$

Ewing's pointed advocacy drew the attention of the Republican majority in Congress, who took the kinetic administrator to task for excessive lobbying and travel. In one such matter, congressional investigators criticized Ewing for an elaborate trip he took to Europe with the apparent purpose of playing up Western Europe's success in building national health insurance arrangements. ${ }^{164}$ In response, Ewing again played the security fugue, insisting:

For more than a year, the Federal Security agency had been working on plans for civilian defense, first at the request of the Department of Defense and later for the National Security Resources Board. We knew that in the United Kingdom the Ministry of Health and the Home Office had done a great deal of planning in this field; and the time had come when it was necessary for us to have face-to-face discussions on the subject.... Our talks covered plans for distribution of medical and related manpower as between civil and military activities in wartime; recruitment, training, and assignment of medical personnel for defense operations;

162 Id at 3 (emphasis added) (arguing that this "security" is a result of the vigilance of the Food and Drug Administration).

163 Id at 4 (presenting the "security" enhancements provided by welfare policy as a bulwark against Communism).

164 See Statement of Oscar R. Ewing, Federal Security Administrator, aboard SS LaGuardia (Jan 17, 1950), available at Harry S. Truman Presidential Library, Papers of Harry S. Truman, President's Secretary's File, Federal Security Agency, Ewing, Oscar: Administrator, Box 125 (concluding that while Western European states "abhor communism," they realize that to stop it they must protect their citizens from "penniless old age, unemployment, disability, and disease"). 
organization of the nation for civil defense; and organization of other health-related services. ${ }^{165}$

These controversies did not stop Ewing's advocacy. Nonetheless, coupled with the advent of the Korean War, congressional pressure kept the FSA from attaining cabinet status and made it marginally harder for the Truman administration to obtain statutory changes expanding health and welfare programs. ${ }^{166}$ The controversies did not, however, diminish the importance of the agency's bureaus to the overall scope of federal activity - even if cabinet status was not obtained until the beginning of the Eisenhower administration..$^{167}$ Neither did they stop the FSA from remaining involved in explicitly defense-related activities, as discussed in more detail below.

\section{Broadening the Scope of "Security"}

Ewing's tendency to parry criticisms of the FSA by playing up the agency's role in national defense had some basis in what the agency actually did. Defense-related activities were a major constant of the FSA as it endured the war years and its responsibilities continued to swell. Increasingly, the FSA framed its essential purpose both to external constituencies and internal employees in terms of national security. "Few ... have better opportunities for service of value both to the armed forces and to the civilian population than those who guard the entrance to the alimentary canal," proclaimed, for instance, a newsletter to FDA employees during the war. ${ }^{168}$ While other domestic agencies occasionally assisted in the war effort, they generally did so by seconding resources or cooperating with temporary wartime coordinating bureaucra$\operatorname{cies}^{169}$ Rarely did those agencies directly assume responsibility for nation-

165 Statement of Oscar R. Ewing, Federal Security Administrator, before the House Select Committee to Investigate Lobbying Activities (July 28, 1950), available at Harry S. Truman Presidential Library, Papers of Oscar R. Ewing, Federal Security Agency, Subject File, General Correspondence, Comptroller General's European Trip, Folder 1, Box 29 (responding to congressional accusations that the trip was designed to circumvent limits on lobbying by emphasizing the civil defense work of the FSA).

166 See Quadagno, One Nation, Uninsured at 30-32 (cited in note 145) (describing the Republicans' "aggressive probe" into Truman's efforts to expand the welfare state and successful efforts to paint Truman's supporters as associates of known Communists).

167 See Leviero, Eisenhower Offers Plan to Give FSA Cabinet Status, NY Times at 1 (cited in note 147). With a Republican Congress, Eisenhower achieved cabinet status for the agency with almost no opposition.

168 Fred B. Linton, Federal Facts and Fancies, 27 Food \& Drug Rev 191, 191 (1943) (admonishing the FDA employees to encourage their efforts during World War II).

169 See, for example, Division of Public Inquiries, United States Government Manual, Winter 1943-1944 at 102-04 (cited in table 1) (explaining the responsibilities of the War Manpower Commission and listing the domestic agencies that had been ordered to cooperate with it). 
al security-related efforts, nor did they (as the FDA did) brand entire regulatory programs as essential to national defense.

In contrast, at nearly every turn the FSA assumed responsibility connected to national security or framed its regulatory activities as essential to the same. Consider some examples from early in the war. The FSA's annual reports emphasized the war-related functions of bureaus such as the PHS, the Office of Education, and the SSB. ${ }^{170}$ The frequently mentioned specific examples were then combined with overarching discussions of the war effort, the importance of national security, and the allegedly deep relationship of both to the health- and welfarerelated work of the FSA. ${ }^{171}$ The SSB paid benefits to bereaved families of the military. Because the agency's mandate at the time included employment placement, the agency served as a conduit to funnel displaced (or otherwise willing) workers into war-related industries. ${ }^{12}$ The Office of Education, its budget swelling during wartime, trained workers for war-related industrial occupations. ${ }^{173}$ So did the National Youth Administration while it continued in existence as part of the FSA. ${ }^{174}$ In Congress, the agency's staff constantly used national security arguments to ask for greater appropriations. The FDA relentlessly promoted its mission "guarding the alimentary canal" and ensuring the flow of safe pharmaceutical products to the armed forces as essential national security functions. ${ }^{175}$ The PHS, working through its NIH unit, devoted a growing share of its resources to defense-related research projects. ${ }^{176}$ The FSA also created specialized war-related units through the FSA administrator's internal reorganization authority. These included the War Research Service to spearhead American biological weapons research $^{17}$ and the Office of Community War Services to provide health and related services to the military and engage in antiprostitution en-

170 See, for example, Federal Security Agency, Annual Reports, For the Fiscal Years 19411942, 1942-1943 at v (cited in note 126) (highlighting the emergency measures taken by the FSA to "meet wartime threats to [the] foundations [of democracy]").

171 See Part IV.D. Regarding the connection between war and the growth of the state generally, see Charles Tilly, European Revolutions: 1492-1992 31-32 (Blackwell 1993) (aphoristically developing the idea that war makes the state). Tilly's account suggests that Roosevelt's strategy for mixing references to national and economic security was not without precedent, but it does not entirely explain the political or legal consequences of the reorganization itself.

172 See Federal Security Agency, Annual Reports, For the Fiscal Years 1941-1942, 1942-1943 at 40 (cited in note 126 ).

173 See id at 18.

174 See id at $50-53$.

175 Dean, 53 Food \& Drug L J at 472-74 (cited in note 129).

176 See Federal Security Agency, Annual Reports, For the Fiscal Years 1941-1942, 1942-1943 at 8 (cited in note 126) (listing, among research requested by the Army and Navy, efforts to procure more plasma, vaccines for various tropical diseases, military aviation, and nutrition).

177 See note 184 for an explanation of the secret status of the War Research Service. 
forcement near military bases. ${ }^{178}$ Working with the War Relocation Authority, the FSA also played a crucial support role in the relocation of Japanese-Americans by serving as a conduit for the provision of benefits and assisting in the placement of Japanese-Americans in approved supervised occupations in the areas to which they were being relocated. ${ }^{179}$ Together, these activities blurred the distinction between national security and the economic and social security that was initially associated with the FSA's bureaus. ${ }^{100}$

Although the agency's defense-related activities had begun before the war and increased in the early phase of the conflict, the pace of these activities quickened as the conflict progressed. Together, McNutt and his assistants formed an agency-wide "Victory Council" to imbue the agency's employees with a sense of mission about the war effort and to obtain suggestions. Letters such as the following poured in:

A suggestion for saving hundreds of pounds of fat in the form of soap. Calgonite or Tri-sodium Phosphate compound can be used for

178 See Federal Security Agency, Annual Reports, For the Fiscal Years 1941-1942, 1942-1943 at 58 (cited in note 126) (describing the Office of Community War Services as "a correlating center for health and welfare activities both within the [FSA] and in other ... organizations").

179 Regarding the FSA's role in relocating Japanese-Americans, see Thomas, Some Social Aspects of Japanese-American Demography, 94 Proceedings Am Phil Socy at 474 (cited in note 18); Comment, Alien Enemies and Japanese-Americans, 51 Yale L J at 1324 (cited in note 18). The FSA's role in the saga of Japanese-American relocation and internment underscores not only the agency's considerable defense-related functions, but also the darker, potentially coercive dimension of an expansive federal capacity. See Polenberg, War and Society at 83 (cited in note 114). Nonetheless, it should be noted that the FSA's role in the internment episode overall was limited compared to that of entities such as the War Relocation Authority. Indeed, the fact that the FSA was not even more heavily involved in the program may reflect the Roosevelt administration's reluctance to assign a publicly controversial assignment to a relatively young agency harboring some of the administrative functions of greatest concern to the president. For a discussion of the administration's difficulty in finding a suitable bureaucratic unit to handle internment, see Tetsuden Kashima, Judgment without Trial: Japanese-American Imprisonment during World War II 33-34 (Washington 2003).

180 See Federal Security Agency, First Annual Report of the Federal Security Administrator at 7 (cited in note 126) (describing the FSA's cooperation with the Advisory Commission to the Council of National Defense); Federal Security Agency, Second Annual Report at 14 (cited in note 126) (discussing tensions between defense emergencies and "the drive toward [domestic] security"); Federal Security Agency, Annual Reports, For the Fiscal Years 1941-1942, 1942-1943 at 1 (cited in note 126) (explaining how the FSA's activities changed between 1941 and 1943 in line with the "rapidly changing conditions" created by World War II); Federal Security Agency, Annual Report, For the Fiscal Year 1944 at vii (cited in note 126) (arguing that concepts and organizations developed during wartime should be retained and expanded during peacetime). See also Dean, 53 Food \& Drug L J at 470-72 (cited in note 129) (discussing the FDA's changing responsibilities as the United States mobilized for war); Swain, Science at 1235 (cited in note 130) (discussing the research activities of the PHS and NIH during wartime); Memorandum from Charles P. Taft to Paul V. McNutt, Admiral McIntire's Testimony before the Subcommittee of the Committee on Appropriations (July 15,1941), available at National Archives, Watson Miller Archive, Federal Security Agency, Entry 10, Box 2 (criticizing a Navy admiral's failure to acknowledge to Congress that the National Institute of Health was engaged in experiments to improve high-altitude military flights). 
washing glass-ware and other laboratory apparatus, and washing dishes in a pan instead of holding soap and glass-ware under faucet and allowing the cleanser to flow down the waste pipe before it is fully used. A few users of great quantities of soap: US Public Health, Regional Laboratories, US Food \& Drug Administration. ${ }^{187}$

As early as 1940, the FSA also became involved in developing a nationwide system to register young men for a military draft. To do this the FSA leveraged its nationwide network of the SSB and US Employment Service offices and its relationship with state employment services. ${ }^{122}$ That same year, the FSA's Office of Education worked with the War Department to design a system of "individual record cards to be issued to students of vocational schools" so they could be more quickly placed in defense-related industries upon completion of their training. ${ }^{183} \mathrm{~A}$ few months later, the president involved the FSA in an interagency committee to "study at this time the question of making some financial provision for the dependents of men in the military service."184

The new structure also served the needs of the political appointees chosen to run it. On occasion, McNutt and his assistants seemed to view the FSA as a national early-warning system for detecting trends among the civilian population that could eventually imperil some expanded version of "national security." Fearing that the simmering possibility of war would begin to siphon young men away from college and into the military, McNutt warned Roosevelt in 1940, "[A] large number of young people who had planned to enter college this September and many of those who attended college last year are intending to interrupt their education to find employment in industries essential to national defense, to enlist in the Army or Navy." ${ }^{\text {"15 }}$ He recommended that Roose-

181 FSA-WMC Victory Council, Meeting Agenda for July 17, 1945, available at National Archives, Watson Miller Archive, Federal Security Agency, Entry 10, Box 1.

182 See Memorandum from Federal Security Agency, Social Security Board, Bureau of Employment Security, to All State Employment Security Agencies (Oct 18,1940), available at National Archives, Federal Security Agency, Classification File, Entry 1, Folder 26, Box 21.

183 See Letter from J.M. Studebaker, Commissioner, Office of Education, to Paul V. McNutt, Administrator, Federal Security Agency, Re: War Department and Office of Education Record Cards Report (Feb 12, 1940), available at National Archives, Federal Security Agency, Classification File, Entry 1, Folder 26, Box 21.

184 Internal White House Memorandum, Summary of Discussion with Director, Bureau of the Budget (circa Sept 30,1940, original correspondence Sept 1, 1940), available at Franklin D. Roosevelt Presidential Library, Federal Security Agency, 1940 Folder, Official File 3700 (emphasizing the role of social assistance in strengthening the war effort by providing for families of those in the armed forces).

185 Internal White House Memorandum, Summary of Correspondence from Paul V. McNutt, Administrator, Federal Security Administration [sic] (circa Aug 14, 1940, original correspondence July 30, 1940), available at Franklin D. Roosevelt Library, Federal Security Agency, 1941 Folder, Official File 3700 (seeking Roosevelt's help in making public statements emphasizing how higher education contributes to national defense). 
velt "advise the young people of the country ... to continue their education and assure them that they will be promptly advised if they are needed for other patriotic services." ${ }^{186}$ White House records indicate the president obliged: "[U]rging college students to continue their education, as any other decision would be unfortunate. Must have intelligent citizens, scientists, engineers, and economists. Patriotic duty of all young people to continue the normal course of their education, unless and until they are called."

This coterie of activities supporting traditional defense-related functions made the FSA stand out even among the larger milieu of domestic agencies that had been enlisted into the war effort. As the war progressed, these functions expanded to include biological weapons research. Such work was controversial even among military officials and Congress; the US government had signed a treaty outlawing such research in 1925 (though the Senate had yet to ratify it). ${ }^{188}$ Once the president was persuaded that the research should include both offensive and defensive applications, he decided that it should occur within the FSA. Funds would be made available from the president's Emergency Fund, which required no elaborate accounting to appropriations overseers. ${ }^{189}$ The FSA boasted a comparatively small and loyal oversight staff $^{100}$ and less-developed relationships to congressional committees compared to the War Department. Moreover, its overt healthrelated mission provided what aides described as "political cover," allowing top university scientists across the country to receive the laundered White House funds without revealing the sensitive nature of their work. After conferring with the president, McNutt selected pharmaceutical mogul George Merck of Merck \& Co to run what became the newest bureau of the FSA, the War Research Service. ${ }^{191}$ McNutt described the early stages of the project thus:

In accordance with our understanding, Mr. George W. Merck has assumed the duties as Director of the Branch of War Research in Chemistry on my staff [sic]. It is my understanding that following

186 Id.

187 Id (paraphrasing Roosevelt's Aug 14, 1940 reply).

188 See note 20 for a description of the treaty.

189 See Federal Security Agency, Annual Reports, For the Fiscal Years 1941-1942, 1942-1943 at 1 (cited in note 126) (explaining that the president had delegated to the FSA responsibility for administering $\$ 5.9$ million of the fund).

190 Consider Bureau of Public Inquiries, United States Government Manual, Fall 1942 at 581 (cited in note 106) (displaying an organizational chart that indicates the office of the FSA administrator had a wide degree of autonomy).

191 See Letter from Paul V. McNutt to President Roosevelt (Sept 4, 1942), available at Franklin D. Roosevelt Presidential Library, Federal Security Agency, 1942-1945 Folder, Official File 3700 . 
the letter which Secretary Stimson wrote you on April 29, 1942, concerning this whole program, you indicated that you would make available $\$ 200,000$ out of our Special Emergency Fund for preliminary expenses. It is desirable now to establish the headquarters office of the organization in the Federal Security Agency. I therefore request that this $\$ 200,000$ be made available for the purposes covered in this program to me as Federal Security Administrator and that an immediate transfer of $\$ 50,000$ be effected for first steps in the program. After a conference with the staff of the Secretary of War, it appears desirable to request that this money be spent as part of the $\$ 25,000,000$ in the proviso of the supplemental national defense appropriation Act for 1943.... It is understood, of course, that all appropriate records will be kept as part of the secret files of the Director and of the Federal Security Administrator. ${ }^{12}$

A further characteristic of the FSA's national security focus is evident in the extent to which the FSA's leadership joined the White House in promoting its elastic conception of "security" during the length of the war and in subsequent years. The public message about the FSA from the White House and the agency's leadership was as ubiquitous as it was simple: "security" encompassed not only explicit warrelated functions but also the agency's more conventional domestic and regulatory responsibilities such as food safety, nutrition education, and public health activities not concerning the military. ${ }^{193}$

Agency activities during the Truman administration amply demonstrated the persistence of defense-related roles and responsibilities well after World War II. Inveigled both by domestic political concerns associated with the Cold War and the Korean War, Truman established

192 Id. See also Letter from George W. Merck, Director, War Research Service to Lt Col Chester W. Goble, State Director, Selective Service System (May 1, 1944), available at National Archives, War Research Service Files, Entry 5A, Box 12. There, Merck explains to a military official the basic outline of the program in order to arrange for a deferment for scientists working on the weapons projects administered by the FSA:

There has been established in the Office of the Administrator of the Federal Security Agency, by verbal Presidential directive, a unit known as the War Research Service. All activities relating to the work of the War Research Service have been classified by the Secretary of War as SECRET. The work is largely research and is carried out in collaboration with a small selected group of highly specialized scientists in universities throughout the country working under Federal Security Agency contracts.

193 See, for example, Memorandum from President Roosevelt to the Federal Security Administrator, US Naval Communications Service (Mar 28, 1941) (with attachments), available at Franklin D. Roosevelt Presidential Library, President's Secretary's Files, Federal Security Agency, Box 134 (approving preparations for a public conference emphasizing the connection between nutrition and national defense). 
an elaborate coterie of national security-related bureaucracies using statutory and executive authority. He set up a National Security Council and a National Security Resources Board. ${ }^{194}$ The latter also included a Federal Civil Defense office combining some of the functions now included in the Federal Emergency Management Agency (FEMA) and the Office of State and Local Coordination within DHS. Nonetheless, the FSA's explicit defense-related functions persisted. It played the preeminent role in health research and assessments relevant to outbreaks of communicable disease, germ warfare attacks, and preparedness of human military resources. ${ }^{105}$ Despite the fact that other agencies were also involved in civil defense efforts, the FSA's role was pronounced. FSA-led functions are mentioned twenty-one separate times in the National Security Resources Board document describing agency missions critical to strengthening defense on the home front..$^{\circ 6}$ And FSA Administrator Ewing along with President Truman continually framed the administration's domestic welfare and regulatory agenda as an element of a broader security policy to disrupt the spread of ostensibly subversive ideas. ${ }^{197}$

The picture that emerges from this narrative is one of FDR as a president who greatly valued the power to reorganize the bureaus that performed administrative and regulatory functions. Given his earlier proposals to Congress and where he first deployed his newly acquired reorganization authority, it seems FDR was especially concerned with those functions involving the White House, public health, social welfare, education, and temporary relief programs he had created earlier in the New Deal. What remains to be addressed is (1) precisely why Roosevelt believed he needed reorganization authority-which could be used to create a new agency-to accomplish his goals; (2) why the FSA blended domestic administrative and regulatory functions with national security ones; and (3) what the merger actually seems to have

194 See Division of the Federal Register, National Archives, United States Government Manual, 1948575 (GPO 1948) (displaying an organization chart that locates the National Security Council and the National Security Resources Board within the Executive Office of the President); Kerr, Civil Defense in the U.S. at 27-30 (cited in note 152) (discussing the Federal Civil Defense Act of 1950 and the creation of the Federal Civil Defense Administration).

195 See National Archives and Records Service, General Services Administration, United States Government Organization Manual, 1950-1951 336 (GPO 1951).

196 See National Security Resources Board, Materials for Use in NSRB Program Development: Preliminary Draft (cited in note 156) (listing the key national defense-related roles of the FSA).

197 See, for example, Truman, State of the Union Address at 6 (cited in note 148) (presenting to Congress key elements of the Fair Deal). 
accomplished. The answers will emerge in part by placing the FSA in the context of theoretical approaches to law and bureaucracy and in part by closely scrutinizing the events that unfolded as Roosevelt's initial reorganization decision culminated some years later in a new cabinet-level superdepartment.

\section{UPDATING THEORIES OF THE POLITICAL DESIGN OF LEGAL MANDATES}

Observers from Max Weber to modern judges and political scientists have readily appreciated politicians' interest in delegating the execution of legal mandates to agencies. Nearly every one of government's legal responsibilities is implemented through such agencies. Bureaucratic structures seem inherent in the very essence of many of the state's legal responsibilities-such as distributing public benefits in accordance with statutory criteria or monitoring private sector behavior for compliance with statutory rules. ${ }^{198}$ The difficulties associated with closing military bases illustrate another rationale for delegation, as doing so allows politicians to achieve desired goals without bearing the full political cost of doing so themselves. ${ }^{109}$ It is also conceivable that politicians may leverage the capacity of agencies to amass expertise and, in the process, solve complicated technical problems important to politicians' goals. These commonly accepted rationales for delegation have something in common. They recognize that a defining feature of the modern administrative state - in both the United States and most advanced industrialized countries - is the delegation of legal power to agencies by strategic politicians.

In contrast to our relatively clear picture of why agencies exist at all, we have a much blurrier image of why they are structured as they are, why their structures or jurisdictions change over time, and what effect bureaucratic structure actually has on legal mandates. The uncertainty does not arise from a lack of potentially compelling explanations but from questions about which of the conventional rationales proves particularly compelling in explaining the fate of a particular agency and its legal mandates. More fundamentally, one might question whether the existing approaches provide a sufficient explanation for all the important bureaucratic phenomena that merit investigation. This Part surveys those approaches and provides a conceptual map for updating them to better explain the trajectory of the FSA and similar entities.

198 See Kenneth McNeil, Understanding Organizational Power: Building on the Weberian Legacy, 23 Admin Sci Q 65, 75-78 (1978) (discussing the application of Weber's theories to understanding why agencies are a vehicle for implementing rules and standards).

199 See Dalton v Specter, 511 US 462, 464-65 (1994) (discussing the legislative structures developed to manage the closure of military bases). 
A. Building Blocks for a Theory of Law and Organization:

Strategic Action, Divided Control, and Crisis

Casual observers of organization theory might be forgiven for assuming that we already known much of what there is to know about how organizational structure affects the implementation of legal mandates. There is little doubt that beginning in the latter half of the twentieth century, scholars greatly clarified our understanding of organizations. We know, for example, that politicians may use the creation of an agency as a means of satisfying a public demand for action on a particular issue ${ }^{200}$ or that they may deliberately set up mechanisms designed to impede organizational effectiveness. ${ }^{201}$ It is also clear from a substantial body of research in institutional sociology and social psychology that organizations may spontaneously develop internal routines and cultures that take on a life of their own, leading individuals and groups to interpret the law in accordance with certain patterns that may or may not correspond to prescriptive standards about those legal mandates. ${ }^{202}$ In more recent years, political scientists and scholars in law and economics have shed light on how bureaus may be understood to be part of a principal-agent dynamic, where politicians make decisions about how to structure organizations and what powers to give them in accordance with their expectations of how those powers will be used. ${ }^{203}$ While all of these perspectives reveal important features of what could be called the organizational logic of legal mandates, case studies of how organizations develop and how they carry out their legal mandates may shed light on crucial questions that remain.

To better understand some of the most prevalent approaches seeking to explain the impact of developments in bureaucratic structure on legal mandates, we might begin by asking how those approaches would explain a change in bureaucratic structure such as the one that created the FSA. Policymakers prefer to treat structural changes as a means of achieving prescriptive benefits, as implied in executive branch state-

200 See Mayhew, Congress: The Electoral Connection at 134-35 (cited in note 12) (discussing how legislatures may enact regulatory acts and create regulatory agencies for "symbolic" value).

201 See Kagan, 114 Harv L Rev at 2257-59 (cited in note 61) (noting the legislative vetoes and "fire alarm" monitoring systems that Congress has built into agency statutes); Cohen, Cuellar, and Weingast, 59 Stan L Rev at 712 (cited in note 26) (arguing that legislative allocation of agency authority is often not designed to achieve stated goals).

202 Regarding organizational culture and routines, see, for example, Charles Perrow, Complex Organizations: A Critical Essay 165 (Random House 1986).

203 See generally B. Dan Wood and Richard W. Waterman, The Dynamics of Political Control of the Bureaucracy, 85 Am Polit Sci Rev 801 (1991). For an insightful treatment of delegation dynamics, see David Epstein and Sharyn O'Halloran, Delegating Powers: A Transaction Cost Politics Approach to Policy Making under Separate Powers 55-59 (Cambridge 1999). 
ments extolling the creation of DHS, Energy, and the National Intelligence Director structure.

But policymakers' claims should be regarded with considerable skepticism. Many legal mandates prove far too ambiguous to let lawmakers or executive branch officials easily discern what organizational changes should be treated as achieving prescriptive benefits. Consider, for example, the new Food, Drug, and Cosmetics Act passed during the New Deal enhancing the power of the FDA; the Social Security Act and its technical complexities; or authority for the PHS to fight infectious diseases. Moreover, history and theory give us considerable reason to question the prescriptive justifications policymakers give for changes in bureaucratic structure. President George W. Bush, for example, pursued the creation of a vast homeland security bureaucracy despite the misgivings of many of his advisers who believed such a move could threaten bureaus' abilities to undertake even security-related functions. ${ }^{204}$ The initial structure of the Defense Department served the interests of the military services at the expense of those of the larger public. ${ }^{205}$ And even when there is little political disagreement, the costs and benefits of reorganization are often highly uncertain and counterintuitive. ${ }^{206}$

As an alternative, one prominent line of scholarship assumes that structural changes primarily involve benefits of symbolic position-taking with no real effect on the implementation of legal mandates. James Q. Wilson's work is one example and even discusses the creation of HEW itself - with no empirical support cited. ${ }^{207}$ This perspective proves especially attractive to those who would consider the development of the state - and of the law-to be most readily controlled by broad social forces. Hence, at one level, the contrast between the views of those who think organizational structure has a limited impact and those who think it is central comes down to a contrast between the sort of macro-level determinism associated with Marx and the focus on hierarchy and organizations reflected in Weber's canonical writings. ${ }^{208}$ Even for those

204 See Cohen, Cuéllar, and Weingast, 59 Stan L Rev at 739 (cited in note 26) (discussing the ambiguous prescriptive benefits of the Bush administration's reorganization of DHS).

205 See Wilson, Bureaucracy at 185-86 (cited in note 23) (explaining how the Defense Department represented a compromise between the Army, Navy, and Air Force regarding their degree of organizational autonomy).

206 See Charles E. Walcott and Karen M. Hult, Governing the White House: From Hoover through LBJ 255-59 (Kansas 1995) (discussing the transaction costs associated with reorganization); Wilson, Bureaucracy at 11-12 (cited in note 23) (suggesting the futility or perversity of some reorganizations).

207 Wilson, Bureaucracy at 267-68 (cited in note 23) (asserting that the component bureaus of HEW "continued for the most part to operate independently" and contrasting this result with the removal of the Air Force from within the Army).

208 See, for example, Max Weber, 1 Economy and Society: An Outline of Interpretive Sociology 225 (Bedminster 1968) (Guenther Roth and Claus Wittich, eds) (Ephraim Fischhoff, et al, trans) 
who consider the development of law and policy to arise in a more dynamic context, there may be reasons to question whether bureaucratic structure tends to prove more than window dressing in light of broad social forces or large-scale political trends. Neorealism in international relations, for example, consistently questions the impact of internal bureaucratic politics and, by implication, of differences in bureaucratic structure. ${ }^{209}$ Other scholars might agree that changes in agency structure are associated with symbolic position-taking activities but emphasize that their impact is to create a dysfunctional agency; ${ }^{210}$ and still others suggest that formal organization spreads along with ideas that become fashionable-regardless of whether they advance political agendas or prescriptive goals. ${ }^{21}$

There is plainly some overlap among these approaches both in terms of how they are deployed as explanations and how they might be defined in principle. But each of these nonetheless reflects a somewhat distinct focus in explaining structure, and, accordingly, each is often deployed as a sort of dominant organizing principle to interpret how developments in structure affect the implementation of legal mandates. Because the focus of this analysis is a detailed case study of a major public agency, the focus is on the more fundamental question of whether existing approaches sufficiently explain how a major portion of the federal government developed. We can begin addressing that question by evaluating the extent to which some of the dominant approaches give a convincing account of bureaucratic structure in a variety of contextsin particular, in the case of the evolution of the FSA.

What soon becomes clear is that the preceding approaches seem to explain some, but not all, facets of organizational structure. If there is a problem with assuming that changes in structure will generally enhance

(discussing the formal rationality of the bureaucracy and the impact of bureaucratic structure on the organization of social life); Anthony Giddens, Capitalism and Modern Social Theory: An Analysis of the Writings of Marx, Durkheim and Max Weber 40-45 (Cambridge 1971) (discussing Marx's deployment of economic determinism).

209 See Barry Posen, The Sources of Military Doctrine: France, Britain, and Germany between the World Wars 34-35 (Cornell 1984).

210 See Moe, $7 \mathrm{~J} \mathrm{~L}$, Econ, \& Org at 125-26 (cited in note 12) (suggesting that a "winning group" in politics might choose to place formal limits on the abilities of a new agency out of fear that in the future, the agency could otherwise act against the group's interest). See also Barry R. Weingast, Caught in the Middle: The President, Congress, and the Political-bureaucratic System, in Joel D. Aberbach and Mark A. Peterson, eds, The Executive Branch 312, 334-38 (Oxford 2005) (describing how the political compromises necessary to get agreement by Congress and the executive branch create a "flawed system").

211 See Strang and Meyer, 22 Theory \& Socy at 491 (cited in note 12) (arguing that institutionalized conceptions of formal organization can spread rapidly because the standardized categories and rules they use provide a "recipe" for adopters). See also Linda M. Lovata, Behavioral Theories Relating to the Design of Information Systems, 11 MIS Q 147, 147-48 (June 1987) (discussing behavioral, nonrational bases for the structure of bureaucratic mechanisms to manage information). 
efficiency, there is also a problem with assuming that reorganizations are purely symbolic. Although institutional sociologists rightly caution that informal routines and cultures may occasionally dwarf the importance of formal lines of authority, other scholars have shown structural changes to matter in a variety of contexts. The creation of DHS led to cuts in Coast Guard environmental activity. ${ }^{212}$ The Carter-era Energy Department, a creation rich with opportunities for the administration to reap symbolic rewards, also centralized power over the Strategic Petroleum Reserve and redistributed control over the national laboratory system. ${ }^{213}$ In short, while questions about the precise impact of structural changes remain to be addressed, it seems more sensible to assume that structural changes will have some effect than to assume they will have none (at least in the absence of context-specific information suggesting that the structural changes are entirely a sham). ${ }^{21}$

Similar problems beset the proposition that changes in bureaucratic structure tend to be motivated by the goal of, and inexorably lead to, dysfunctional organization. Some changes in bureaucratic structure are not plainly dysfunctional, such as the creation of the Joint Chiefs of Staff or the Federal Reserve Board. It is not clear why the Roosevelt administration would want some of the agencies and programs for which it had fought so hard-including the SSB, the FDA, plus legacy New Deal agencies such as the National Youth Administration or the Civilian Conservation Corps-to be "dysfunctional." Even defining what counts as "dysfunctional" is beset by conceptual difficulties similar to those associated with defining "success" in the implementation of legal mandates. ${ }^{215}$

Finally, there is a problem with explaining structure primarily through the spread of ideas that become popular among the public or policymaking elites and are adopted without conflict. This perspective

212 See Cohen, Cuéllar, and Weingast, 59 Stan L Rev at 727 (cited in note 26) (quoting a longtime Coast Guard observer who noted that the Coast Guard had to curtail its traditional regulatory activities in order to take on its new security-related mission).

213 See id at 748 (questioning Carter's stated reason for creating the Energy Department and arguing that his true purpose was to shift oil price regulation and nuclear weapons research from independent agencies to the White House).

214 See Amy B. Zegart, Flawed by Design: The Evolution of the CIA, JCS, and NSC 131-62 (Stanford 1999) (discussing the Joint Chiefs of Staff); Walcott and Hult, Governing the White House at 12-13 (cited in note 206) (describing how structure can influence the conduct of overtly political tasks); Moe, $7 \mathrm{~J} \mathrm{~L}$, Econ, \& Org at 123 (cited in note 12) (arguing that political institutions, which result from structural choices, are "means of legal coercion and redistribution" and therefore the choice of structure can make some groups better or worse off); G.L. Bach, The Machinery and Politics of Monetary Policy-making, 8 J Fin 169, 170-71 (1953) (discussing the relative political consensus surrounding the Federal Reserve).

215 See Zegart, Flawed by Design at 26 (cited in note 214) (arguing that legislators face substantial information problems when determining the success or dysfunction of foreign policy agencies). 
may explain why dysfunctional states in African nations have science ministries when they have essentially no science going on, but it does not account for the intense strategic activity and political conflict surrounding structural questions in many advanced industrialized nations. The creation of the FSA, for example, was part of a long-term struggle over whether health, welfare, and security responsibilities would be concentrated in a single, powerful agency. It strains both theory and historical analysis to assume that all of this reflected the diffusion of ideas, nor can that rationale fully account for the striking differences that persist in bureaucratic structure across nation-states. ${ }^{216}$

\section{Centrality of strategic action.}

Eager new lawmakers from politically polarized districts, seasoned Senate committee chairmen secure in their reelection, recently confirmed agency commissioners, White House advisors, and lawyers representing organized interests often differ in what they want from government. Their very ideas about ultimate goals may be confused or uncertain. But in the contested arena of the regulatory state, what these actors have in common is an impulse toward strategic action. It is all but impossible to make sense of organizations without assigning a central role to the strategies political actors use to pursue their goals. Too much is riding on who supervises an organization, what officials make ultimate judgments of fact and value, whose legal advice is considered authoritative, and who controls purse strings to assume that choices about organizational structure only occasionally or intermittently provoke strategic behavior.

As used here, the reference to strategic behavior simply suggests that legislators, executive branch officials, and organized interests seek to achieve concrete goals through changes in structure. Precisely what those goals are may vary to a considerable degree. Some participants, such as legislators imposing procedural requirements on administrative agencies, may be interested simply in improving their ability to monitor what bureaucratic organizations do. The National Rifle Association's interest in the responsibilities of agents at the Bureau of Alcohol, Tobacco, and Firearms may stem from its keen sense that a bureau whose budget is held constant while shouldering additional responsibilities

216 Compare Strang and Meyer, 22 Theory \& Socy at 499 (cited in note 12) (stating that new nation-states adopt organizational forms that have already been designed and legitimated by others), with Wilson, Bureaucracy at 295-97 (cited in note 23) (contrasting rules-oriented bureaucrats in the United States with Western European regulators who have more discretion over how to apply regulations). 
may be less able to carry out regulatory activities. ${ }^{217}$ Regardless of the content of its goals, however, the challenge of achieving its objectives may encourage participants in the bargaining over bureaucratic structure to act in ways that are at odds with their public pronouncements.

Scholarly observers and legal practitioners commonly recognize that statutes and regulations are shaped by strategic action. But why would bureaucratic structure -in effect, the rules governing where in the United States Government Manual certain bureaus appear and what officials are listed as being in charge of them-be subject to strategic activity? After all, it is not difficult to think of examples where organizational realities fail to conform to bureaucratic structure. Despite the fact that former FBI Director J. Edgar Hoover was nominally a subordinate of the attorney general, he stopped behaving like one soon after becoming director. ${ }^{218}$ Conversely, nominally independent agencies such as the Federal Reserve Board and the NLRB may be subject to political influence through appointments and appropriations. ${ }^{219}$ With these examples in mind, some observers may be skeptical about the importance of bureaucratic structure. They might even deploy a simple political "Coase theorem," implying that bureaucratic changes are unlikely to have much importance, perhaps only reflecting preexisting distributions of political power. In effect, they would suggest that-perhaps other things being equal-formal bureaucratic structures do not matter much in a world where organized interests, legislators, and politicians have some mix of interests and powers to direct what public organizations actually do. ${ }^{220}$ This conclusion might be bolstered by a particularly expansive reading of the work on institutional sociology and social psy-

217 See William J. Vizzard, In the Cross Fire: A Political History of the Bureau of Alcohol, Tobacco, and Firearms 27-28 (Lynne Rienner 1997). See also Daniel C. Richman, Federal Criminal Law, Congressional Delegation and Enforcement Discretion, 46 UCLA L Rev 757, 796-97 (1999).

218 On Hoover and the FBI, see Athan G. Theoharis, The FBI and American Democracy: A Brief Critical History 32-36 (Kansas 2004) (describing how, despite the attorney general's order barring investigation of individuals' political beliefs, Hoover expanded political investigations and encouraged citizens to become "confidential informants").

219 With respect to political influence on the Federal Reserve, see Kelly H. Chang, Appointing Central Bankers: The Politics of Monetary Policy in the United States and the European Monetary Union 66-71 (Cambridge 2003). Political control of the NLRB is analyzed in Terry M. Moe, Control and Feedback in Economic Regulation: The Case of the NLRB, 79 Am Polit Sci Rev 1094, 1108 (1985) (finding that haif of the variance in NLRB decisions can be explained by political conditions, economic conditions, and NLRB staff filtering of caseloads, but that over time the NLRB's decisions equally favor labor and business).

220 See Daron Acemoglu, Why Not a Political Coase Theorem? Social Conflict, Commitment, and Politics, $31 \mathrm{~J}$ Comp Econ 620, 633-48 (2003) (showing how application of the political Coase theorem is limited by the fact that contracts between citizens and the state are, by definition, not enforceable, and suggesting that the use of incentive-related promises can sometimes overcome this issue). 
chology emphasizing the limits of formal structure in reshaping norms, routines, and informal networks that arise within organizations.

Yet formal bureaucratic structure is the legal backdrop against which the policymaking game is played. Though formal structure rarely tells the whole story of organizational power over legal mandates, most participants in the drama of governance proceed on the assumption that hiring decisions, policy priorities, budget requests, office assignments, and future career advancement all depend to some extent on formal lines of bureaucratic authority. Politicians and interest groups engage in bitter fights over whether an agency should be a commission or a typical administrative agency, whether a position should be subject to Senate confirmation, or whether, for example, the US Biological Survey should be an independent bureau of the Interior Department or a subsidiary office of the US Geological Survey. ${ }^{22}$ The recurrence and intensity of these fights suggest something other than mass delusion about the importance of bureaucratic structure. Moreover, existing work in political economy and sociology suggests that structure can have effects by conditioning residual decisionmaking rights and shaping expectations (both internal and external) regarding accountability. Even the territory of modern administrative law suggests that structure is likely to matter because it determines who decides how to interpret an ambiguous legal mandate..$^{223}$ In effect, arguing that lines of organizational jurisdiction are entirely inconsequential is likely to be as difficult as arguing that lines of geographic jurisdiction are inconsequential. The relevance of bureaucratic structure is also supported by theories grounded in sociology, political science, economics, and psychology. Broadly speaking, institutional sociology, political economy, and social psychology approaches all suggest that formal lines of authority, jurisdictional limits, and formal hierarchical arrangements should be expected to change how legal mandates are carried out. The effects may not be salutary, intended, or obvious. Nonetheless, from an intellectual perspective, it is a radical position indeed to suggest that formal organizational structure should routinely have no effect on how legal mandates are carried out. ${ }^{24}$

221 With respect the expansive readings of institutional sociology and social psychology, see Mark Granovetter and Charles Tilly, Inequality and Labor Processes, in Neil J. Smesler, ed, Handbook of Sociology 175, 205 (Sage 1988) (reporting that large, bureaucratic private firms experience the same bifurcation between private and organization goals seen in government bureaucracies); Philip Selznick, An Approach to a Theory of Bureaucracy, 8 Am Soc Rev 47, 50-51 (1943) (developing an analytical model of bureaucracy where conflicts between the goals of individual bureaucrats and the formal goals of the organization create a new, informal structure).

222 See Lewis, Presidents and the Politics of Agency Design at 92-97 (cited in note 22).

223 See Chevron U.S.A. Inc v NRDC, 467 US 837, 842-43 (1984).

224 See id. 
Politicians have repeatedly treated structure as particularly important in the context of health, education, and security. Major legislative fights occurred in connection with Roosevelt's reorganization plans over Truman's efforts to elevate the FSA to cabinet status and (earlier) over whether to create a federal health department. Moreover, while there is next to no scholarship specifically on the FSA or even on the development of HEW, what little is known suggests that the FSA's existence was eventful and perhaps even momentous. Between the late 1930 s and the early 1950 s - when HEW became a fixture of the president's cabinet - the FSA's bureaus matured. The FDA and the Social Security Administration radically expanded their budgets. ${ }^{2.5}$ The NIH effectively began their modern existence as the premier funders of federal intramural medical research. ${ }^{26}$ And the public heard countless times from high-level presidential appointees how intimately connected the federal government's health and welfare functions were to the overall success of the American national security effort. ${ }^{27}$

\section{Divided control and prescriptive ambiguity.}

If strategic action is a recurring feature of the process shaping bureaucratic jurisdiction over legal mandates, then divided control is nearly always its corollary. Even dictators rarely have an entirely free hand in shaping their bureaucracies. Despite the fact that FDR himself was often accused by political elites of seeking dictatorial powers through reorganization, the reorganization powers he sought in 1938 would have been exercised in the shadow of legislative control. This was even truer with the powers he obtained under the 1939 reorgani-

225 Compare Budget of the United States (1935) (showing a total budget for the two agencies of slightly more than $\$ 1.5$ million), with Budget of the United States (1950) (growing to $\$ 1.3$ billion with almost $\$ 5$ million of this total appropriated for the FDA and the remainder appropriated for the Social Security Administration). See also Martha Derthick, Policymaking for Social Security 272-73 (Brookings 1979) (discussing the growth in social security expenditures during this period); Gilbert, The United States Food and Drug Administration (cited in note 56) (chronicling the agency's growth in the decades after World War II).

226 See Swain, Science at 1236 (cited in note 130).

227 See Oscar R. Ewing, Conservation in Terms of Our Human Resources 23 (speech presented at the Utica Sesquicentennial, Utica, New York, July 3, 1948), available at Harry S. Truman Presidential Library, Papers of Oscar R. Ewing, Federal Security Agency, Speeches and Articles, 1948-1949, Box 38:

Today, in terms of military and productive strength, we are the greatest nation on earth ....We are strong. Yes. But we must maintain our vigor. And above all we must conserve both our natural and our human resources. For in the last analysis it is from the land and the people that a nation derives its real strength.

See also Polenberg, War and Society at 84-86 (cited in note 114) (discussing how the Farm Security Administration's defenders sought to avoid budget cuts by positioning it as a "first-line war agency" that would 'help in meeting the food needs of wartime America"). 
zation bill, which were subject to a one-house congressional veto. It is now widely understood that lawmakers share power over bureaucracies with the executive through their control of substantive statutory mandates, budgets, oversight activity, and procedural requirements. Indeed, presidents pursue reorganization in part to bolster their interests in the midst of lawmakers' efforts to assert their own power.

But the reality of divided control is important beyond the confines of legislative-presidential interaction. With so much at stake in decisions about organizational structure, bureaucratic officials and organized interests often support fragmented control, with one agency controlling initial regulatory decisions and another commanding enforcement. Hence, the Department of Health and Human Services-the principal descendant of the FSA - decides on chemical exposure limits for workers while the Labor Department's Occupational Safety and Health Administration (OSHA) enforces those provisions. ${ }^{229}$ Even when political pressures do not explicitly favor divided control, fragmentation of legal responsibilities becomes commonplace given preexisting bureaucratic divisions and the enormous complexity associated with some legal mandates. Thus, anti-money laundering policy is best understood not as a federal function designed to achieve a coherent goal, but as a mix of statutory decisions controlled by prosecutors, rulemaking choices governed primarily by regulators, and investigative decisions mostly in the hands of criminal investigators. Because it is such a common feature of the allocation of bureaucratic authority, divided control is both a contributor to pressures for change in structure - as presidents and organized interests maneuver for advantage-as well as a constraint on how those changes are implemented.

It is not impossible to anticipate how bureaucratic structure will affect the success of legal mandates. But given the breadth of many such mandates, along with the political divisions about what counts as "success," it becomes extremely difficult to connect particular structures to some defensible concept of "success." The difficulties are complicated by the gaps in our knowledge of bureaucracy. Together these factors

228 See Wilson, Bureaucracy at 268 (cited in note 23). See also Part III.B; Lewis, Presidents and the Politics of Agency Design at $70-87$ (cited in note 22) (discussing why presidents would want to use structural changes to undo congressionally imposed constraints on presidential control).

229 See Office of the Federal Register, United States Government Manual 2007-2008 223, 288 (GPO 2007) (describing the work of the Agency for Toxic Substances and Disease Registry and the division of labor between OSHA and HHS on chemical exposure limits for workers).

230 See Cohen, Cuéllar, and Weingast, 59 Stan L Rev at 713 (cited in note 26) (discussing divided control of occupational safety policy). See generally Mariano-Florentino Cuéllar, The Tenuous Relationship between the Fight against Money Laundering and the Disruption of Criminal Finance, $93 \mathrm{~J}$ Crim L \& Criminol 311 (2003) (discussing the consequences of the fragmentation of control in the anticriminal finance system among prosecutors, regulators, and investigators). 
should make one skeptical of bald assertions, such as those frequently made by FDR, about the capacity of reorganization to promote "efficiency" in the strict sense of the term. One must recall that there is considerable uncertainty about the extent to which particular types of bureaucratic structures will contribute to "effectiveness" in achieving consensus goals associated with the implementation of legal mandates. Even when a probability exists that a particular structural changesuch as centralization of functions - will have a given impact, key audiences, such as members of the mass public, may not appreciate the extent to which desired effects are contingent on complex factors such as the nature of congressional organization. Given the pervasive reality of divided control of bureaucracies, there are strong reasons to question the conventional prescriptive case for reorganization. Organizational changes carry relatively certain costs. In contrast, prescriptive benefits are contingent on potential complexities arising from the impact of organization on an agency's legal activities. (For example, adjudication of immigration benefits will probably experience different effects compared to an agency's regulation of an economically powerful industry. $)^{231}$

\section{B. Theoretical Refinements: Capacity-building, Coalition Expansion, and Endogenous Crisis}

Although the history of the FSA and of other structural changes seems to confirm the importance of some of the preceding dynamics, it may also provide an opportunity to develop some refinements on the approach described above. Such refinements may be especially helpful in addressing the persistent puzzles about the FSA's creation.

\section{Capacity-building.}

Just as politicians may sometimes reap rewards by appearing to address a problem while creating an agency that will fail to do so, in other cases their goals could give them a great stake in the ability of a bureaucracy to carry out complicated tasks. Whether those tasks actually fulfill a president's publicly asserted goals is not the primary issue. The point is to recognize that politicians may have a good deal riding on building bureaucratic capacity. For example, Dutch politicians rec-

231 As noted earlier, legal mandates are often too ambiguous and subject to contested interpretations to yield a consensus idea about what counts as "effectiveness" from a prescriptive perspective. Disagreement about goals thus makes it difficult to fix-conceptually-what it means for an agency to be structured in a prescriptively effective manner. Even when there is relative political consensus about underlying goals, we have limited existing knowledge of how changes in bureaucratic structure actually affect the implementation of legal mandates. 
ognize how their fortunes are tied to the success of the nation's levee system and have every reason to bolster the capacity of that bureaucracy to perform effectively. ${ }^{232}$

Most statutory mandates are naturally subject to more controversy. The PHS's forays into rural health inspired as much support among poor farmers as they did scorn among private doctors' associations, who saw such moves as the first step of a campaign to nationalize health insurance. The Food, Drug, and Cosmetic Act continues to this day to mean one thing to government regulators and another to pharmaceutical companies. But even-and perhaps especially - when there is an absence of political consensus, presidents or their aides may seek additional resources to enlarge the layer of superiors overseeing an agency's functions, so these can be better controlled or (in some cases) protected from political attacks. ${ }^{233}$

If a president persuades Congress to create a new layer of executive branch officials above the bureaus that carry out the government's work and the president can fill those ranks with loyal officials, he can better control how agencies carry out their functions. He can cement emerging political coalitions by ensuring that agencies carry out their missions in a favorable manner. He can use the new layer of appointees to blunt the influence of legislators and organized interests seeking to assert control over agencies. He can align existing bureaus-such as the PHS, which was originally a minor office of the Treasury Departmentunder new superiors who will devote more time and energy to using the bureau's resources and building a distinctive organizational culture, thereby facilitating the development of statutory proposals or policy initiatives advancing presidential goals.

These opportunities do not guarantee that executive branch officials will want bureaus to work as effectively as possible: recall that even defining effectiveness beyond extreme cases like the levees in Holland soon becomes taxing. Moreover, building up agencies with new bureaus, leaders, and resources is not without risk. As the experience of FEMA in handling Hurricane Katrina indicates, the creation of a new superagency such as DHS can be associated with major set-

232 See Nicholas Pinter, One Step Fonward, Two Steps Back on U.S. Floodplains, 308 Science 207, 208 (2005) (discussing the consensus supporting the Dutch levee system and its oversight structure). See also Stephen Skowronek, Building a New American State: The Expansion of National Administrative Capacities, 1877-1920 145-48 (Cambridge 1982) (describing how railroad bankruptcies and destabilizing rate wars spurred Congress to create the Interstate Commerce Commission).

233 See Polenberg, Reorganizing Roosevelt's Government at 7 (cited in note 22) (stating that Roosevelt believed that the true purpose of reorganization was to make the administration "more responsive to the national interest"); Walcott and Hult, Governing the White House at 18 (cited in note 206) (proposing that the emergence of a White House staff can be viewed as a response to mounting demands on the president to formulate domestic policy and monitor executive branch agencies). 
backs in performance. ${ }^{24}$ Likewise, bureaus such as the National Park Service can use new resources to bolster their independence from politicians. Despite these risks, some politicians may have good reason to enlarge bureaucratic capacity while protecting agencies from legal changes that would set them up for failure. Faced with opponents who would rather keep bureaucracies weak and difficult to monitor, proponents of bureaucratic capacity should be especially inclined to take advantage of windows of opportunity for political change that emerge during (actual or imagined) crises. ${ }^{235}$

\section{Coalition expansion.}

Why did the Roosevelt administration entrust so many defenserelated functions to the FSA? The answer may depend on whether changes in bureaucratic structure have the capacity to alter the public's responses to political appeals. The loading up of FSA with defense functions may also shed light on how politicians, such as Roosevelt, Jimmy Carter, and George W. Bush, use agency reorganizations to affect the distribution of power among policymakers, thereby reshaping the implementation of legal mandates.

Most work on bureaucratic structure has little to say about the reactions of the mass public except, perhaps, to note that politicians can gain some political credit by making structural changes to soothe preexisting public demands. Yet the position-taking opportunities associated with bureaucratic structure at least show that bureaucratic matters can occasionally break through the public's inattention barrier. Because questions of structure may register with voters, we might ask whether changes in agency jurisdiction can nudge the public's demand for particular policies rather than merely follow those demands. Consider: if a grant program for funding youth education and community centers is run by the Justice Department rather than the Department of Housing and Urban Development, how might public perceptions about those grant programs change? Presumably, the answer depends on the underlying mechanisms through which individuals form opinions and

234 See Cohen, Cuéllar, and Weingast, 59 Stan L Rev at 739-41 (cited in note 26) (arguing that structural problems related to the reorganization of FEMA into DHS turned Hurricane Katrina into an especially large crisis).

235 See Daniel P. Carpenter, The Forging of Bureaucratic Autonomy: Reputations, Networks, and Policy Innovations in Executive Agencies, 1862-1928 30-33 (Princeton 2002) (discussing techniques bureaucracies use to foment relative political independence); Daniel P. Carpenter, Adaptive Signal Processing, Hierarchy, and Budgetary Control in Federal Regulation, 90 Am Polit Sci Rev 283, 288-89 (1996) (discussing how new layers of bureaucracy blunt the impact of legislative strategies to control the bureaucracy); Gavin Wright, The Political Economy of New Deal Spending: An Econometric Analysis, 56 Rev Econ \& Stat 30, 30-31 (1974) (discussing econometric studies of the allocation of grant funds during the Roosevelt administration). 
on the extent to which associating community grants with crime control can evoke more favorable associations among politically relevant constituencies. The possibility of such an effect, however, is enough to suggest that politicians could use organizational structure, like legal doctrine, to carry on a conversation with the public and elites about the essential nature of particular government programs. Such a process could implicate several of the building blocks just mentioned, especially position-taking, expertise, and forging political coalitions. This makes it important to answer the question of whether it is possible for the politics of structure to have an "epistemic" dimension relevant to conflict over the merits of particular legal and policy functions alongside the more conventionally acknowledged policy control dimension.

In contrast to situations where politicians support reorganization in response to preexisting public demands-as with Richard M. Nixon's creation of the EPA, Carter's design of the Energy Department, or Bush's campaign to forge DHS - an alternative strategy would deploy reorganization to foment public demand for a particular statutory mandate. First, the reorganization itself could deliver a means of generating media attention, which is one reason why organizational changes are also useful to politicians who want to assuage a concern already present among the public. ${ }^{236}$ By the same token, politicians can use the attention to focus concern on a new issue that advances their political agenda. Second, some proportion of voters may become more supportive of statutory mandates if politicians supply a new version of what political scientists describe as a "policy metaphor": a narrative to organize the relationship between widely shared concerns and policy prescriptions. Not everyone is amenable to new policy metaphors. Someindeed, perhaps most-members of the public may expend considerable cognitive effort to resist such appeals. But just a few people reexamining at energy law as a component of environmental policy, for example, or food safety as an element of national security, may tip the scales in favor of more aggressive regulatory expansion. Third, policy elites favoring one agency mission over another may have a harder time deciding whether to withhold support for an entire agency when doing

236 See Cohen, Cuéllar, and Weingast, 59 Stan L Rev at 684-86 (cited in note 26) (describing public demand for increased security and how it eventually led to the creation of DHS); Wilson, Bureaucracy at 130 (cited in note 23) (discussing politicians' different reasons for supporting organizational changes); Charles O. Jones and Randall Strahan, The Effect of Energy Politics on Congressional and Executive Organization in the 1970s, 10 Legis Stud Q 151, 158-59 (1985) (discussing the creation of the Energy Department). 
so may also restrict the functions they value $e^{27}-$ a point developed in more detail below.

Executive branch officials might achieve an additional benefit by mixing functions in a new bureaucracy. By modifying the bundles of adjudication, expenditures, investigation, and legislative activity undertaken by bureaucracies, executive officials could fashion a new relationship between bureaucracies and more conventionally rational-but skeptical-political elites such as lawmakers. The key idea is that weaving national security functions into the fabric of a domestic agency changes the political game for legislators who would have preferred to cut administrative and regulatory programs. Once mixing has occurred, the lawmakers' choice is beset by two new complications: the possibility that by cutting domestic programs the legislators are genuinely hobbling defense, which may run counter to their own political goals; and the risk that even if such adverse effects never materialized, some members of the mass public might now ironically punish the legislators for cutting defense-related programs. In short, creating bureaucracies could involve more than just passively exploiting a crisis such as an impending or actual war. The very act of creating the bureaucracy can help reshape how the public understands the role of government, the scope of a crisis, and the nature of the "security" that the resolution of the crisis would presumably entail. ${ }^{238}$

\section{Endogenous crisis.}

While agency architecture can drive the law's implementation, natural disasters, national security emergencies, or the recent economic crisis can in turn shape agency architecture. But what does "crisis" actually mean? Upon closer inspection, there may be more to crisis than the simple idea of an unexpected, exogenous shock.

If crisis can be the handmaiden of legal change, we should also expect certain factors to drive lawmakers' or executive branch officials' capacity to argue about the presence of a crisis. Undoubtedly some of what seems like a crisis in retrospect reflects an exogenous shock, such as an unexpected, sharp upswing in the number of Haitian asylum seek-

237 See Mark Schlesinger and Richard R. Lau, The Meaning and Measure of Policy Metaphors, 94 Am Polit Sci Rev 611,613-14 (2000) (developing a model of reasoning by policy metaphor); Peter Burnell and Andrew Reeve, Persuasion As a Political Concept, 14 Brit J Polit Sci $393,394-400$ (1984) (discussing how attitude change occurs as the result of new information or symbolic imagery).

238 See Michael M. Ting, A Theory of Jurisdictional Assignments in Bureaucracies, 46 Am J Polit Sci 364, 365-67 (2002) (describing how politicians face difficulties when they consider restricting funding for an agency that performs both functions that they value and those that they do not value as much). 
ers requesting entrance to the United States, an economic recession, or a terrorist attack. As a variation on this theme, rapidly crumbling political fortunes faced by a coalition or an individual political actor can also spur action because of further expected deterioration that could occur in the absence of some response. Nixon's firing of Archibald Cox and other Justice Department officials may be an example. ${ }^{2.9}$ Separate from the underlying shock itself, officials in a presidential administration, lawmakers, and other political actors can use their agenda-setting power to coax public attention toward the conclusion that a crisis is underway. Senator Estes Kefauver's hearings on the dangers of thalidomide and drug safety in the early 1960s are an example: even though the FDA had in fact blocked the drug from being sold in the United States, the senator leveraged public concern over the episode to create a crisis atmosphere contributing to statutory expansion of the FDA's power. ${ }^{240}$ Finally, a position taken by actors external to the political branches, such as organized interests, can contribute to the public perception that there is a crisis-particularly if the position is unexpected. ${ }^{241}$ Think of a Supreme Court opinion taking a position on the quality of evidence about global warming, ${ }^{242}$ an oil company unexpectedly acknowledging the existence of global warming, ${ }^{243}$ or an individual from a party historically opposed to immigration reform proposing a guest worker program. ${ }^{24}$ By the same token, public officials' desire to pursue politically costly legal changes such as the creation of new bureaucracies, or even the use of controversial interrogation techniques, could play a role in fostering public perceptions that the country faces a particularly difficult period. ${ }^{245}$ Because the true nature of a crisis is difficult to observe, members of the public may find themselves drawing inferences from the behavior of politicians. The more public officials are willing to shoulder the costs of a particular legal change or policy prescription, the greater the perceived magnitude of a crisis may be among the public. Each of the foregoing choices could help political actors foster an im-

239 See generally Richard Reeves, President Nixon: Alone in the White House 604-05 (Simon \& Schuster 2001). The "Saturday Night Massacre" firings were not specifically a change in agency structure but rather an effort to use a preexisting structure and to test the limits of the president's ability to control that structure.

240 See Cohen, Cuéllar, and Weingast, 59 Stan L Rev at 708-09 (cited in note 26).

241 See James D. Fearon, Signaling versus the Balance of Power and Interests: An Empirical Test of a Crisis Bargaining Model, 38 J Conflict Res 236, 252 (1994).

242 See Massachusetts v EPA, 549 US 497, 521-23 (2007).

243 See Russell Gold and Ian Talley, Exxon CEO Advocates Emissions Tax, Wall St J B3 (Jan 9,2009).

244 See Michael A. Fletcher and Darryl Fears, Bush Pushes Guest-worker Program, Wash Post A02 (Nov 29, 2005).

245 Consider James D. Morrow, How Could Trade Affect Conflict?, 26 J Peace Res 481, 484 (1999); Fearon, $38 \mathrm{~J}$ Conflict Res at 258 (cited in note 241). 
pression that a crisis is afoot. Yet these actors often face a devilish tradeoff between facilitating desired policy change by fostering a perception of crisis and paying the political costs associated with being viewed as not effectively or appropriately managing that crisis. ${ }^{246}$

These dynamics should underscore the difficulty of deciding when exactly a genuine crisis fully emerges, in prescriptive terms. To a considerable degree, the contemporaneous or even historical perception that a crisis has occurred probably emerges endogenously from political choices made by presidents, executive branch officials, lawmakers, courts, and organized interests. By contrast, the prescriptive analysis of what counts as a crisis depends on a combination of close scrutiny to a specific temporal and policy context - the number of lives affected after a natural disaster, the extent of a slowdown in credit markets, or the extent of exposure to toxic contaminants after an industrial accidentalong with a sense of the goals of the evaluation. Because such evaluations are difficult in a world of limited information and of voters with cognitive constraints, one should expect considerable room for politicians to play up the crisis theme in pursuit of achieving the desired legal architecture for agencies charged with governing.

\section{Shaping law by altering organizational evolution.}

Most of the theory presented so far develops the idea that external conditions affect organizations implementing the law. The FSA and its bureaus depended on external support. External constraints could interfere with agency plans, whether they involved new regulations expanding food safety inspections or secret biological weapons programs. Nor is the FSA unique in this regard: no account of the law's implementation works without considerable attention to the external context.

But if agencies are a product of their environment, so too are they occasionally capable of shaping that environment to some extent. Agency officials can facilitate or impede the adoption of legislation reshaping the organization's architecture, as when Congress sought to cut off nuclear security functions from the rest of the Department of Energy in the mid-1990s. ${ }^{247}$ Civil servants can lay the groundwork for subse-

246 This tradeoff describes Franklin Roosevelt's situation in the years immediately before the entry of the United States into World War II, particularly as he navigated a period of transition from insisting that American forces would not participate in the European war to underscoring the dangers of that war to the interests of the United States. See Heinrichs, Threshold of War at 83-85 (cited in note 115) (describing the considerations that went into Roosevelt's May 27, 1941 speech on the strategic threats facing the United States).

247 See Lewis, Presidents and the Politics of Agency Design at 110-15 (cited in note 22) (describing Congress's influence on Department of Energy reforms taken in response to allegations of espionage at Los Alamos National Laboratory). 
quent statutory changes and in some cases even use limited legal authority autonomously to pursue goals later mandated by statute. FDA employees are a case in point, having articulated and accepted innovative legal arguments to pursue efficacy testing of drugs before it was required by statute. ${ }^{248}$ These examples merely illustrate how external pressures on agencies can coexist with, and in some cases are even premised on, attempts to control the autonomous agendas of agency staff.

So what happens when the possibility of autonomy and the reality of external pressure intersect? Across the constellation of interests within and around an agency, it remains possible that some players will be all too aware of an agency's potential capacity to acquire a greater measure of autonomy over time, as it builds an external constituency of support or acquires an ever stronger reputation for technical competence. After all, not all agencies are in the same position to protect themselves from external interference. For example, the Federal Reserve Board-sitting firmly at the more autonomous end of the spectrum - acquired its relatively more independent status gradually, thereby becoming harder to challenge over time. ${ }^{2.9}$

If lawmakers, executive branch officials, and organized interests recognize that budgets and formal organizational constraints could affect agency behavior in the present, they could also recognize that an agency's capacity for autonomy over time depends on a host of factors that could be controlled in the near term. Potentially important but subtle variables contributing to autonomy over time, such as the cohesion of an agency's internal culture, may depend on factors that can be controlled by external actors in the near term, such as where in the larger scheme of government an agency is located (for example, whether a parent cabinet agency supports a bureau's overall mission or views it as peripheral), what an agency's capacity is to generate technical knowledge (thereby affecting whether the organization can use a reputation for scientific or technical competence to bolster autonomy), and whether it is overseen in its early phases of development by political officials sympathetic to the agency's likely trajectory as it gains independence. Accordingly, we might examine the history of the FSA to see if the structural moves that created it could have contributed to changes in the relative autonomy of its bureaus over time.

248 See Carpenter, Forging of Bureaucratic Autonomy at 366 (cited in note 235) (describing how the FDA's prompt action generated substantial public goodwill for the agency and, as a result, Congress expanded the agency's powers).

249 See generally Bernard Shull, The Fourth Branch: The Federal Reserve's Unlikely Rise to Power and Influence (Praeger 2005). 


\section{APPLYING THE THEORY}

That federal authority could be a double-edged sword was nowhere more clearly illustrated than in the evacuation of Japanese-Americans from the West Coast, a process facilitated by a number of New Deal welfare agencies .... The ease with which relief programs could serve the cause of relocation suggested that such a massive and efficient movement of people would have been immeasurably more difficult before the advent of the social service state. $^{250}$

On April 26, 1939, readers of the nation's paper of daily record awoke to the following headline: President Decrees Three Big Offices in Centralizing 21-Relief, Social Security and Lending Agencies Grouped in Reorganization Message-A Warning to Dictators-Democracies Need Not Always Be Weak, He Says, but Must Keep Tools Up to Date. ${ }^{2{ }_{1}}$ Under the Reorganization Act of 1939, readers learned, a new Federal Security Agency would be born along with two smaller agencies-as long as no house of Congress approved a resolution disfavoring the plan. While the immediate consequences of this move were clear enough to readers of the nation's newspapers that morning, Part II suggested that our theoretical tools to explain why and how politicians decide whether to create agencies such as the FSA are incomplete. In particular, such theories should more thoroughly address how structural changes allow politicians to simultaneously assert greater control over agencies, build their capacity, and reshape how political elites and the mass public understand a bureaucracy's mission.

This Part provides support for those theoretical refinements. Its focus is on demonstrating how presidents can control the bureaucracy by building bureaucratic capacity and how they can enlarge support for regulatory and administrative activities by engineering bureaucracies to reshape public views and to bolster legislative coalitions. The payoff is not only in better understanding what happened with a major portion of the federal government housed at FSA and its successor agencies, but also in elucidating how political actors more generally shape legal mandates through organizational choices that parallel and interact with their decisions about how to interpret statutes and legal doctrines.

250 Polenberg, War and Society at 83 (cited in note 114).

251 Belair, President Decrees Three Big Offices in Centralizing 21, NY Times at 1 (cited in note 22). 


\section{A. Augmenting Capacity for Presidential Control}

1. Motivations: more control, and more to control.

It is helpful to begin by reviewing what the White House had at stake with the bureaus that were folded into the FSA. Unlike most other presidents then or since, Roosevelt had previously served in a senior position within the executive bureaucracy. He arrived into that bureaucracy via a position as assistant secretary of the Navy in the palatial State, War, and Navy Building, where he sat behind the same massive mahogany desk his cousin Theodore Roosevelt had occupied in the same position decades earlier. ${ }^{252} \mathrm{He}$ began learning firsthand of the political techniques lawmakers used to control bureaus. ${ }^{253} \mathrm{He}$ decried the formal legal independence of bureaus within the Navy Department, which allowed bureau chiefs to bypass the Navy Department and even the president in their dealings with Congress. ${ }^{254}$ For an astute young assistant secretary, these constraints naturally led him to acquire a measure of human capital optimized for the task of strengthening of control-even in a legally restrictive environment-over bureaus whose performance could so heavily impact his political future. ${ }^{2.5}$

Against the backdrop of these experiences, it should have been only too clear to Franklin Roosevelt the president two decades later how much the political context gave the White House a cluster of overlapping reasons to be concerned about the bureaucracy in general, and particularly about the fate of key regulatory and administrative bureaus with major new or politically important responsibilities (for example, the FDA, the PHS, the SSB, and the Office of Education). First, Roosevelt's insistence on reorganization authority, and his almost immediate use of that authority once he obtained it, reflects the challenges he faced in dealing with the increasing political controversy associated with the New Deal. Perhaps largely as a result of the president's own determination to wring maximal policymaking advantage from his 1936 electoral victory, the administration's allies in Congress had dwindled by $1938 .{ }^{256}$ The Republicans had gained eighty seats in the legislature

252 See Jean Edward Smith, FDR 101 (Random House 2007).

253 See id at 102-03 (explaining that congressional opposition prevented the Navy Department from reorganizing its inefficient "quasi-independent bureaus" that had been designed in the "age of sail").

254 See id at 103.

255 See id (quoting Roosevelt as saying, "I get my fingers into just about everything and there's no law against it").

256 Some secular decline in political support is possible, but the decision to shed marginal members and reorient the Democratic Party towards the Northeast and activist government was probably more important. See Polenberg, Reorganizing Roosevelt's Government at 183-84 (cited in note 22) (describing Roosevelt's decision to "purge" the Democratic Party of conservatives); 
that year. ${ }^{257}$ It was not inconceivable that the growing ranks of New Deal opponents would seek to block presidential efforts to carry out the new legal mandates-for which he had secured approval-by trying to assert legislative control over the bureaucracies. Opponents could impose administrative burdens on bureaus, seek subtle but significant technical changes in the underlying legislation that would limit the scope of regulatory powers, or restrict the budgets funding agency operations. ${ }^{2.8}$ Indeed, an increasingly threatening political environment should have led the White House to desire more political control of bureaus in the short term even if it eventually wanted those entities to become impervious to political manipulation by less sympathetic presidents. ${ }^{259}$ In effect, the White House would have found itself in a stronger position to make use of scarce agency resources to serve a range of political goals (including, perhaps, growing the political autonomy of prized programs) if it had secured greater control over the bureaus in the short term, and realigned agency responsibilities to facilitate the bureaus' growth in the longer term. Whatever concerns Roosevelt or his staff may have had about how subsequent presidents might use greater authority over the bureaus would have been mitigated somewhat by the fact that nearly 50 percent of the president's second term remained. And even well before World War II, the notoriously optimistic Roosevelt had copiously declined to rule out a third term.

The White House's rocky time expanding Social Security illustrates the stakes. Social Security only expanded to cover farm-related employment by $1950{ }^{261}$ But before then, its advocates sustained a number

McNollgast, $15 \mathrm{~J}$ L, Econ, \& Org at 190-91 (cited in note 44) (explaining how, at the time of the Roosevelt administration and in succeeding years, civil rights issues split the Democratic Party into a New Deal wing and a Southern element that formed coalitions with Republicans).

257 See Polenberg, Reorganizing Roosevelt's Government at 184 (cited in note 22) (noting that despite Republican gains in Congress, the Reorganization bill of 1939 passed "with little difficulty").

258 See Sundquist, Dynamics of the Party System at 215 (cited in note 27) (discussing the growing political power of opponents to the New Deal).

259 The existing literature on "policy insulation" seems to ignore the possibility that politicians' desire to create ultimate, long-term autonomy in bureaus might lead them to desire more, not less control in the short term to create the conditions that increase the probability of bureau autonomy in the longer run (among others, these would likely include a constituency of public supporters, a more favorable portfolio of missions, actual or perceived technical competence, and a preferred position in the interagency process). Because short-term control could actually strengthen longer-term autonomy, politicians would face a host of interesting strategic problems in seeking to calibrate the timing of control. In a democratic system involving a measure of uncertainty over who will wield control in the long run, policymakers might ideally seek to secure enough control to shape the architecture of public programs in the long term without allowing the residual amount of control they secure to be used by subsequent politicians desirous of reengineering the federal bureaucracy.

260 See Smith, FDR at 411 (cited in note 252) (describing how FDR "encouraged and exploited" speculation that he might run for a third term, and suggesting that in all likelihood he had not made up his mind).

261 See Derthick, Policymaking for Social Security at 264 (cited in note 225). 
of defeats in trying to move toward expansion. Even the SSB sometimes rejected opportunities for expansion. Early on, supporters of Social Security were among those who were cautious. Some urged that the focus should be on private, wage-earning employment to simplify administrative burdens on the agency at the time when it would be most vulnerable. The role of the SSB illustrates the stakes for Roosevelt in trying to assert greater control over the bureaucratic structures associated with his programs. At the same time, the link between bureaucratic capacity to supervise program administration and further expansion suggests that the president could have had incentives to expand the resources that could be made available to the SSB by subsuming it into a larger agency that could draw on the budgets and capacities of other agencies (and indeed, the Labor Department-related functions transferred into the FSA were in fact placed at the disposal of the SSB). ${ }^{262}$

With tighter control over administrative bureaus, the White House could also steer a growing stream of federal grants in a manner that could simultaneously fulfill their statutory purposes while cementing the new Democratic coalition. Three of the bureaus administering some of the largest national grant programs at the time-the SSB, the PHS, and the Office of Education - were among those moved to the FSA. ${ }^{263}$ By the second half of the 1930s, the federal government had increased resources and legal authority to provide grant funds to states and localities. Just four years before the FSA's creation, significant legislative changes further opened the spigot of federal grant money that would eventually be housed within the new superagency. ${ }^{264}$ States received a growing amount of funds for public assistance, child and material health, unemployment compensation, child welfare, and (through the PHS) the provision of medical services in underserved areas. ${ }^{265} \mathrm{Al}-$ though the grants came with strings requiring the development of merit systems for staffing the new programs, the statutory enactments left the administration a measure of flexibility for directing where the funds were spent. ${ }^{266}$ Indeed, some historians have suggested that the Roosevelt administration sought to direct funding to states that were politically supportive. ${ }^{267}$ But with grant funds and bureaucracies expanding,

262 See id at 263-64.

263 See notes 15 and 126.

264 See Leuchtenburg, Franklin D. Roosevelt and the New Deal at 132 (cited in note 27).

265 See id.

266 See Miles, The Department of Health, Education, and Welfare at 15 (cited in note 13) (discussing the range of grant programs transferred to the FSA and the requirement for the state-level merit systems that contributed to the unraveling of patronage-based control of relief funds).

267 See Wright, 56 Rev Econ \& Stat at 38 (cited in note 235) (suggesting that "Roosevelt might well have lost the election" without the support of those who received federal employment as a result of his policies). 
the administration may have had a particular interest in increasing its capacity to monitor how grants were being administered and where funds were going. In addition, temporary relief entities such as the National Youth Administration were folded into the new agency. The president insisted through his advisers that "all projects of [the $\mathrm{Na}$ tional Youth Administration] [ ] be presented to him for approval." ${ }^{\text {6s }}$

Second, the often-complex new mandates for which the administration had secured approval required growth in the bureaucracy. The National Labor Relations Act, the Food, Drug, and Cosmetic Act, and the Social Security Act were not capable of carrying out their own functions without an army of lawyers, clerks, supervisors, and analysts. As the bureaucracy grew, the president's own capacity to supervise and control how that bureaucracy carried out the mandates remained limited. ${ }^{20}$

Third, even before the outbreak of the war, the White House sought to carry out certain projects in relative secrecy. The strong existing relationships-even back then-between legislators and certain established departments such as War and Navy made this more difficult than it might have been at a new, subcabinet agency with fewer existing links to Congress and a leaner bureaucratic structure. ${ }^{270}$

Fourth, there is likely something to an account occasionally developed in the political science literature discussing how the president's connection to a national constituency likely makes him somewhat more interested in the extent to which the bureaucracy can achieve relatively widely held political goals. ${ }^{27}$ Other things being equal, one should expect legislators to have a comparatively lesser interest in "efficiency" (as one might refer to the capacity of the bureaucracy to achieve widely held political goals) because only rarely are individual legislators sufficiently identified with government performance to make it worth their

268 See Internal White House Memorandum (Aug 11, 1939), available at Franklin D. Roosevelt Presidential Library, Federal Security Agency, 1939 Folder, Official File 3700. See also Miles, The Department of Health, Education, and Welfare at 15 (cited in note 13) (discussing the range of grant programs transferred to the FSA and the requirement for the state-level merit systems that contributed to the unraveling of patronage-based control of administrative activity). For analyses of the political rationales affecting the allocation of grant funds, see John Joseph Wallis, Employment, Politics, and Economic Recovery during the Great Depression, 69 Rev Econ \& Stat 516, 519 (1987) (arguing that Wright's model overstated the impact of politics and that New Deal administrators targeted spending at states with lower employment levels); Wright, The Political Economy of New Deal Spending: An Econometric Analysis, $56 \mathrm{Rev}$ Econ \& Stat at 33 (cited in note 235) (finding that a political model of New Deal spending explains between 59 and 80 percent of the variance in per capita spending from 1933 to 1940 ).

269 See Charles O. Jackson, Food and Drug Legislation in the New Deal 192 (Princeton 1970) (describing the legal burden the Food, Drug, and Cosmetic Act's judicial review provisions placed on the FDA); Dean, 53 Food \& Drug L J at 458-59 (cited in note 129) (showing the growth in FDA appropriations and staffing after enactment of the Food, Drug, and Cosmetic Act).

270 See Zegart, Flawed by Design at 70-71 (cited in note 214).

271 See, for example, id at 16. 
while to sacrifice jurisdiction-specific gains in exchange for benefits at the national level. ${ }^{2 n}$ Hence, veterans' opposition to the creation of a Department of Welfare should be expected to sway a legislator in a district with a large concentration of veterans and no countervailing political pressures even if the performance of the federal government as a whole would be enhanced by the move. ${ }^{2 / 3}$ Presidents, in contrast, face fewer "common pool" problems. ${ }^{2 / 4}$

\section{Adding a layer of political staff.}

As it forged the new FSA, the White House sought to achieve its objectives precisely along the lines of what the theory developed above would imply. The creation of the FSA established a new layer of political appointees loyal to the president, a new staff to oversee the bureaus' legal determinations, and a capacity to develop and advocate for legislative proposals that could cut across different agency functions at a time when the White House staff-even after the White House-related changes in reorganization - was tiny. All of these changes made it easier for the president to monitor policy developments, control how legal authority was deployed in the present, and control how proposals for future statutory and regulatory changes were developed.

272 See Cohen, Cuéllar, and Weingast, 59 Stan L Rev at 706-07 (cited at note 26).

273 See Polenberg, Reorganizing Roosevelt's Government at 80-81 (cited in note 22) (describing how veterans' organizations, through "a steady salvo of letters to Washington," were able to force Roosevelt to promise not to transfer the Veterans Administration).

274 See Cohen, Cuéllar, and Weingast, 59 Stan L Rev at 706-07 (cited at note 26); Zegart, Flawed by Design at 16 (cited in note 214) (discussing presidential incentives for enhanced functioning of bureaucratic activities that are likely to be valued by national political constituencies). But see generally Jide Nzelibe, The Fable of the Nationalist President and the Parochial Congress, 53 UCLA L Rev 1217 (2006) (questioning the presumption that presidents have unwavering incentives to focus on nationwide policy concerns while Congress focuses on parochial concerns). While Nzelibe may be right that some plausible scenarios involve presidential parochialism and congressional concern with nationwide policy implications, the White House is still likely to care about broad public opinion more than the relevant lawmakers (such as the median lawmaker, the leadership of relevant committees serving as vetogates, or the pivotal lawmaker in an enacting coalition). First, lawmakers delegate some measure of authority to committees that can be made up of preference outliers. See, for example, John Londregan and James M. Snyder, Jr, Comparing Committee and Floor Preferences, in Kenneth A. Shepsle and Barry R. Weingast, eds, Positive Theories of Congressional Institutions 168 (Michigan 1995) (finding that one-third of Committees in the House of Representatives, from 1951 to 1984, were preference outliers when compared to the entire House). Thus, the members of the House Judiciary Subcommittee on Immigration are likely to come from districts that care more about immigration policy than the typical lawmaker. Second, the White House's ability to command attention from the general public more easily than even the most powerful lawmakers is likely to make support from the mass electorate a more realistic counterweight to concentrated regional, sectoral, or economic interests in presidential deliberations Third, even controlling for scale and acknowledging some presidential focus on competitive states with large concentrations of electoral votes, the relevant constituencies for the president tend to be more diverse (with a greater mix of offsetting concentrated interests) than those of the typical legislative jurisdiction. 
The most immediate consequence of the FSA's creation is plain from comparing the United States Government Manual of 1940 or 1941 to that of 1938 or $1939 .^{275}$ The reorganization yielded for the White House the bounty of a new staff to monitor the activities of a bundle of government bureaus. ${ }^{276} \mathrm{~A}$ job description for one of the junior analysts in what became Paul McNutt's office at FSA headquarters gives an inkling of what these appointees might accomplish:

[R]esponsibilities primarily along the following lines: (1) Maintaining current knowledge of all policies, programs, and procedures involved in the work of the United States Public Health Service, the Food and Drug Administration, the Health and Medical Committee of the Office of Defense Health and Welfare Services, and all other Governmental organizations whose activities bear upon health problems. (2) With respect to the Public Health Service this involves an understanding of various projects and programs and the objectives of such operations particularly in their non-technical aspects; with respect to the Food and Drug Administration this involves an acquaintanceship with the meaning and intent of various standards and policies, procedures with respect to legal actions, and the relation of specific cases to other work in the Food and Drug Administration.

Such officials augmented what was, by twentieth-century standards, a paltry White House staff. They also expanded what even quite loyal staff at existing executive departments could accomplish in overseeing the bureaucracy. The challenge of departmental staff management was all the more acute if the department's (and the political staff's) reputation depended more heavily on performing core functions unrelated to those of the soon-to-be-transferred bureau. Thus, beyond the fact that the FSA added generally loyal supervisory staff, the concern of Treasury political appointees about the PHS was unlikely to ever approximate that of the FSA's appointees. ${ }^{278}$ Nor was the president shy in using that new layer of staff for developing policy proposals that leveraged both the administrative expertise and perceived competence of the FSA. For example, when Truman asked FSA Administrator Oscar Ewing to use the agency to promote national health insurance, Ewing responded with an FSA-prepared report purporting

275 See note 126 for an overview of the changes in the United States Government Manual during this time period.

276 See Walcott and Hult, Governing the White House at 101 (cited in note 206).

277 Federal Security Agency, Employment Position Classification Sheet (circa 1943), available at National Archives, War Research Service Files, Entry 5A, Box 12.

278 See Polenberg, Reorganizing Roosevelt's Government at 81-82 (cited in note 22). 
to draw on the experience of the agency's full complement of bureaus to urge adoption of national health insurance legislation. ${ }^{279}$

Because the White House staff was small and other mechanisms of bureaucratic control (including partisan patronage politics) were fraying, the White House sought to add a layer of political staff that facilitated the White House's monitoring and control of bureaus placed within the FSA. In effect, the creation of the FSA allowed the president to move agencies such as the FDA and the SSB, changing their structure to make them more amenable to oversight.

\section{FIGURE 3}

WHITE HOUSE EMPLOYEES, 1934-1980

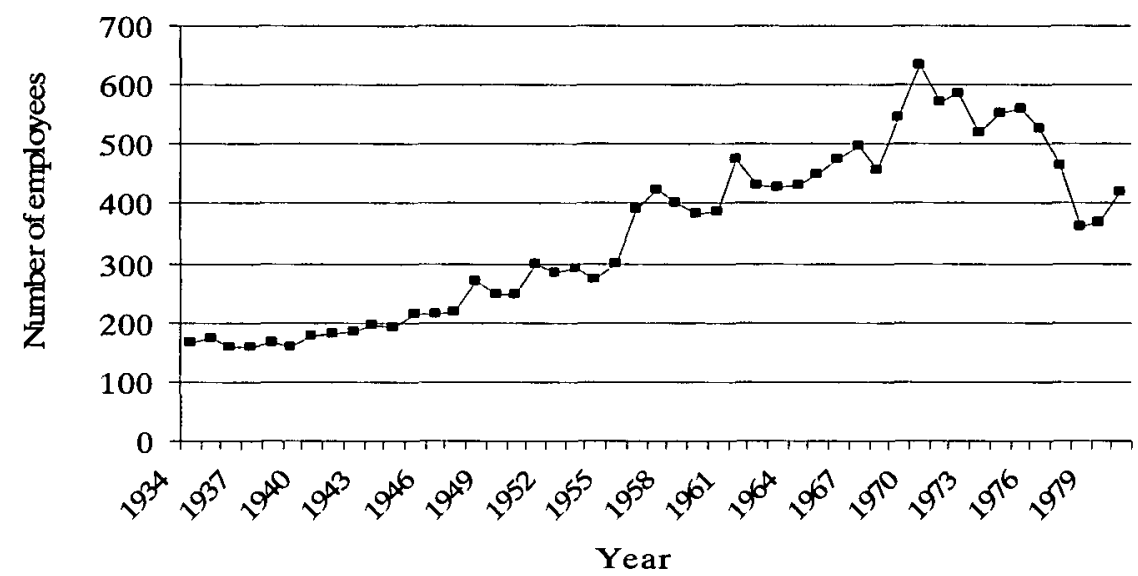

Source: Based on data in Charles E. Walcott and Karen M. Hult, White House Staff Size: Examples and Implications, 29 Pres Stud Q 638, 641-42 (1999).

As Figure 3 indicates, the White House staff in the 1930s was tiny compared to what it would be a few decades later. Meanwhile, the executive branch was expanding. Some of this expansion was among the military, but a substantial chunk of it was occurring among the ranks of civilian executive branch workers. ${ }^{200}$ In this environment, the creation of the FSA added a layer of political and administrative appointees to oversee the bureaus. For instance, the SSB was an independent agency

279 See Quadagno, One Nation, Uninsured at 30 (cited in note 145) (recounting how after Ewing convened a National Health Assembly, which did not endorse national health care, he released his own analysis that did).

280 See US Census Bureau, Statistical Abstract of the United States 2003: Mini-historical Statistics 94 table HS-50, online at http://www.census.gov/statab/hist/HS-50.pdf (visited Apr 14, 2009) (detailing year-by-year Executive Branch employment numbers, from 1901 through 2002, for the Department of Defense, civilian agencies, and the Post Office). 
that lost its independence under the plan and did not regain it again until the mid-1990s. ${ }^{281}$ Because the goal of monitoring and controlling government functions depends in part on such staff, the White House sought to increase the size of that staff beginning in the late 1930s. But the Roosevelt administration also sought substitutes for the White House staff increases in the form of new layers of political appointees to oversee existing bureaus and in the form of initiatives limiting the formal legal insulation from presidential control of independent commissions such as the SSB. ${ }^{228}$

Along with the SSB, all the bureaus within the FSA would now report to the administrator and his senior staff. The agency head, moreover, would be vested with the legal authority to undertake all the agency's functions. Even with respect to the bureaus that were not previously independent as a matter of law, the officials associated with the new FSA structure represented a net increase in the number of staff available to monitor bureaus (compared to the status quo), with the significance of the staff accentuated by the fact that it would be dedicated to monitoring certain bureaus, such as the PHS, that had previously received relatively meager attention in their original bureaucratic homes. ${ }^{283}$

281 See 42 USC $\$ 901$.

282 See Walcott and Hult, Governing the White House at 101 (cited in note 206) (explaining how Roosevelt used the administrative assistant posts provided for by the Reorganization Act of 1939 to create new oversight mechanisms of executive branch agencies). See also Matthew J. Dickinson, Bitter Harvest: FDR, Presidential Power, and the Growth of the Presidential Branch 112-13 (Cambridge 1997) (characterizing Roosevelt's administrative response to the growth in government programs as "a small White House Office supported by a vastly expanded institutional staff"). For a discussion of Roosevelt's initiatives to limit the SSB, see Part I.A.

283 See Federal Security Agency, Organizational Charts FY 1952 (cited in note 105) (presenting the lines of reporting and authority within the FSA). 
FIGURE 4

PERCENTAGE OF EXECUTIVE BRANCH EMPLOYEES

WORKING AT THE WHITE HOUSE, 1934-1980

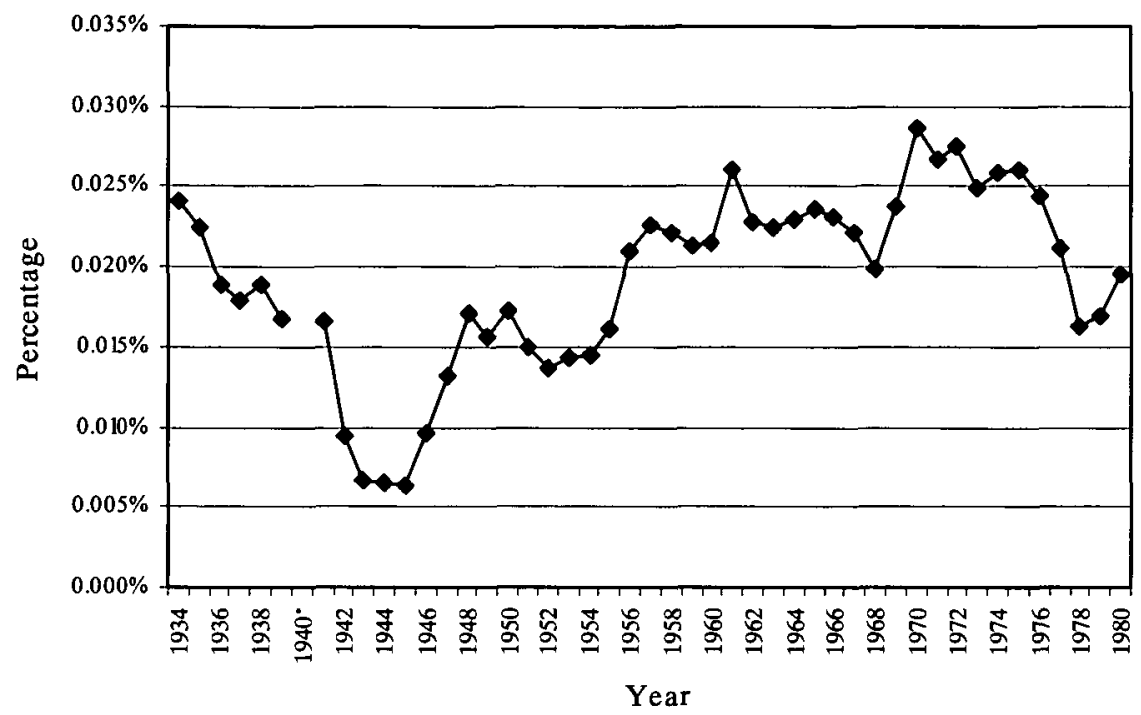

*Due to changes in the source of data for total executive branch employees, the data point from 1940 is omitted Sources: Based on author's calculations from data in Walcott and Hult, 29 Pres Studies Q at $641-42$ (cited in figure 3); US Census Bureau, Statistical Abstract of the United States 2003 at 94 table HS-50 (cited in note 280).

The difficulties associated with White House monitoring and control of the executive bureaucracy can be further appreciated by examining the percentage of federal executive branch employees working at the White House. As early as 1934, that ratio was falling and could be anticipated to fall even further. Even if Roosevelt succeeded in gradually expanding the purview of the White House to include new federal employees temporarily loaned on detail from existing departments and the Bureau of the Budget, the task of overseeing bureaucratic activity was becoming ever more challenging for the White House. If legislators would continue restraining growth in White House staff, the White House could respond by changing the oversight structure directly responsible for the bureaus-both by increasing the number of politically loyal overseers as well as by reallocating legal authority over bureaucratic responsibilities and vesting it more clearly in higher-level officials. ${ }^{24}$

284 See Walcott and Hult, Governing the White House at 78-79 (cited in note 206) (providing a summary of Roosevelt's efforts to create an executive branch composed largely of New Dealers). 
The consequences of the FSA's new position, allowing it to better monitor its bureaus, were not lost on participants at the time. The president had tremendous interest in "trying to find some method by which he and future presidents would be relieved of a certain amount of paper work and a certain amount of personal conferences" and believed that "this had been in great part accomplished through the Reorganization"-in part through the creation of the Federal Security Agency. ${ }^{235}$ Along with this goal, the president's staff sought a "reduction in [the] number of independent agencies," such as the SSB, which had been designed by Congress to limit presidential control. ${ }^{286}$ While public administration intellectuals such as Louis Brownlow insisted on crediting reorganization for nearly every American wartime success, internal White House documents belie the administration's insistence that reorganization was meant to advance widely held social goals rather than presidential power. ${ }^{27}$ Lest there be any doubt about the White House's actual goal of using efficiency to benefit the president, an internal White House memorandum setting forth the guiding principles for using the president's coveted reorganization powers provides further insight:

[A]s a guide to the timing of steps in reorganization the following is suggested: First, do those things which when done will reduce the difficulties of the President in dealing with his multifarious duties and which will assist him in discharging his responsibilities as the chief administrator of the government. Second, do those things which when done will advantage the work of those administrative

285 Internal White House Memorandum, Summary of Correspondence from Dr. H.A. Morgan, Chairman of the Board, Tennessee Valley Authority (Sept 23, 1939), available at Franklin D. Roosevelt Presidential Library, Federal Security Agency, 1939 Folder, Official File 3700 (indicating Roosevelt's interest in relieving pressure arising from the scarcity of time and staff).

286 White House Memorandum on Administrative Organization: General Recommendations (1939), available at Franklin D. Roosevelt Presidential Library, Papers of John Winant, Box 157.

287 An article published in 1944 provides one of several examples of Louis Brownlow's persistent campaign to promote the wisdom of the reorganization with which he was so intimately involved:

In our own country the administrative success has been the greatest of all .... There were the indignant protests of those who believed that if this were not changed, or if that were not done, or if t'other were not stopped, the war was lost. Military men saw too much civilian interference, civilians too much military control. Industrialists feared the coddling of labor; labor feared the coddling of industry; farmers feared they were being neglected; and everybody else had his fears, too. Experts in every specialty wrung their hands as they saw their particular prescriptions seemingly tampered with by amateurs. Nobody was satisfied. Yet, despite all this (maybe because of all this), the success was achieved.

Louis Brownlow, Reconversion of the Federal Administrative Machinery from War to Peace, 4 Pub Admin Rev 309, 309 (1944). Brownlow also argued that the reorganization plan that led to the creation of the FSA would make it easier to "reconvert" federal activities to peacetime challenges after the war. See id at 313. 
aides who have been chosen by the President to assist him in the discharge of his duties ... whose responsibility to the people is through the President. (These two purposes may be accomplished by (1) reduction of the number of independent agencies reporting directly to the President, and (2) better organization of the managerial arms of the President-budget, planning and personnel agencies). Third, do those things which when done will advantage heads of departments in the discharge of their own responsibilities. (This can be accomplished by bringing together scattered agencies dealing with the same functions so that the heads of departments may better plan and coordinate their work). ${ }^{2.8}$

Roosevelt, as the assistant secretary of the Navy, could have written a similar memorandum decades earlier and indeed did at the time exalt the notion of executive accountability functioning through cabinet (and subcabinet) officials reporting to the president. ${ }^{28}$

The nature of these goals as they map onto the competition between branches becomes even clearer in the next passage of the analysis, which is styled as a "historical note":

[D]uring the era of legislative encroachment on executive prerogative the President's assistants (cabinet officers et al.) have had direct access to Congressional committees denied to the President and often have unwittingly aided in the process of undermining Executive authority by making parochial trades with special interest committees in the Congress. A thorough reorganization will give the Congress the benefit of the considered and rounded knowledge and opinion of the whole Executive Branch rather than, as has been so often the case, the specialized opinion of a particular part of the administrative corps.

It is an interesting fact that few federal administrators have spoken to the members of the President's Committee on Administrative Management in terms of the interest of the President or the presidency or the Administration-but nearly always in terms of the immediate and particular interest of a department or a bureau as if it were satrapy. ${ }^{200}$

288 Internal White House Memorandum, Reorganization (Apr 16, 1939), available at Franklin D. Roosevelt Presidential Library, President's Committee on Administrative Management, Correspondence and Papers, Folder on Reorganization Plan 1, Box 24 (emphasis added).

289 See Smith, $F D R$ at $102 \mathrm{n} 13$ (cited in note 252) (quoting the assistant secretary of the Navy seeking reforms to make bureau chiefs more directly responsible to the central Department of the Navy bureaucracy).

290 Internal White House Memorandum, Reorganization (cited in note 288) (emphasis added). 
The analysis proved to be more than theory. It was, in fact, precisely the view articulated by subsequent FSA officials explaining their role in overseeing the agency's coterie of bureaus. Paying no regard to the complexities associated with statutory grants of authority to subordinate officials, Oscar Ewing was particularly explicit about his perceived duty to the White House when testifying before the House Select Committee on Lobbying Activities in 1950:

The department head must be regarded as an extension of the President's personality. He is expected to carry out any basic instructions which a President may provide for his guidance .... Furthermore, a department head is expected to provide a certain political point of view to departmental operations. He must be more than a mere channel of communication between the department and the President for vital matters on which the latter must make a decision. The department head should bring a political attitude to all departmental affairs. Such a political attitude is not to be defined in terms of a narrow partisanship .... Rather, a political attitude reflects prevailing beliefs on broad public issues, beliefs about the scope and magnitude of Government activities, about both the ends and means of government action. ${ }^{291}$

With the president's new political appointees more tightly controlling the FSA's bureaus, they assisted the White House in monitoring regulatory developments at the agencies, giving political speeches about the FSA's work across the country, ${ }^{29}$ and developing new policy and legislative proposals that often, in turn, led to increased budgets. Given the extent to which the reorganization changed the White House's capacity to control bureaus, it is surprising that some observ-

291 Official Verbatim Transcript of Statement of Oscar Ewing before the House Select Committee on Lobbying Activities (BNA July 28, 1950), available at Harry S. Truman Presidential Library, Papers of Oscar R. Ewing, Federal Security Agency Subject File, General Correspondence, Comptroller General's European Trip, Folder 1, Box 29 (responding to questions from lawmakers about the relationship between a senior federal agency administrator and the president).

292 Telegram from Stephen Early, Secretary to the President, to the Honorable Paul McNutt, Federal Security Administrator (Oct 10, 1939), available at Franklin D. Roosevelt Presidential Library, Federal Security Agency, 1939 Folder, Official File 3700 (relaying to McNutt an invitation from the governor of Nebraska to give a political advocacy speech).

293 See Bureau of the Budget Staff, Recommendations for Interdepartmental Transfer (Apr 24, 1939), available at Franklin D. Roosevelt Presidential Library, President's Committee on Administrative Management, Correspondence and Papers, Reorganization (1939), Folder on Interdepartmental Transfer, Box 24 (recommending the transfer of certain independent agencies into the White House reporting structure). See also Internal White House Memorandum, Other Reorganization Proposals (circa Apr 1939), available at Franklin D. Roosevelt Presidential Library, President's Committee on Administrative Management, Correspondence and Papers, Reorganization (1939), Folder on Interdepartmental Transfer, Box 24 (indicating the president's decision to have some agencies transferred after the FSA's first year of operations). 
ers believe presidential control of the bureaucracy is a relatively recent development. Elena Kagan's magisterial account of presidential administration is an example. Although Kagan acknowledges the significance of some battles over reorganization, such as the conflict over Roosevelt's 1938 reorganization plan, ${ }^{205}$ she still describes the trajectory of presidential control by emphasizing the innovations of the Clinton administration. ${ }^{26}$ These techniques, including taking credit for rulemaking and using the White House staff to monitor bureaucratic developments, surely enhanced presidential control at a time when the White House confronted a politically empowered and Republican-controlled Congress. ${ }^{297}$ But presidential administration at the end of the twentieth century was in fact foreshadowed by the uses and consequences of organizational structure in the 1940s and 1950s. ${ }^{298}$

3. Changing the organizational environment affecting presidential goals.

New organizational structures altered the context of decisionmakers who wielded statutory authority. Even when the White House could not directly monitor what bureaus were doing, the work of bureaus could be shaped by placing these in organizational environments more amenable to the missions that the administration supported. Recall that the AMA explicitly wanted the Public Health Service to remain at Treasury at one point; the bureaus were in agencies that made their work almost certainly peripheral (the Office of Education, in the Interior Department, faced the same situation). ${ }^{29}$ The Agriculture secretary eventually made a half-hearted effort to keep the FDA in his department in $1940 .^{300}$ When the former Bureau of Chemistry was nonetheless transferred to the new health and security agency, the bureau's employees faced a new political equation. Agricultural interests lacked the same close relationship they had enjoyed with the Agriculture Department's leadership.

294 See generally Kagan, 114 Harv L Rev 2245 (cited in note 61).

295 See id at 2274-75.

296 See id at 2284-2303.

297 See id at 2311-15.

298 See Kagan, 114 Harv L Rev at 2274 (cited in note 63) (discussing the "incipient efforts" of Roosevelt and Truman to exercise control over the federal bureaucracy).

299 See Polenberg, Reorganizing Roosevelt's Government at 82 (cited in note 22).

300 See Jackson, Food and Drug Legislation in the New Deal at 181-82 (cited in note 269) (describing a letter written to the president by Agriculture Secretary Wallace in which he stated that he would recommend veto of the reorganization plan if it was not amended).

301 See Polenberg, Reorganizing Roosevelt's Government at 82 (cited in note 22); Dean, 53 Food \& Drug L J at 456 (cited in note 129). 
The importance of shifting the organizational context was not lost on the White House. Facing daunting practical constraints when seeking policy results from government bureaus, administration officials understood themselves to be changing the agencies' political environment as a means of bolstering policy goals. Return to the internal White House analyses of Reorganization Plan No 1 discussed in Part I. Although they contain a brief reference to the rhetoric about "democracy" found in public statements about the plan, the analyses quickly define a specific version of democracy that emphasizes the importance of presidential control, the goal of strengthening functions considered critical by the White House, and-crucially - the value of changing the existing relationship between bureaus, interest groups, and Congress. ${ }^{32}$ Even if changes at the top of the hierarchy did not guarantee policies more aligned with the president's goals, at a minimum these provided an opportunity that could be exploited to scramble and complicate existing relationships between external organized interests, bureaus, and their legislative overseers.

4. Using a broad mandate as cover for sensitive projects.

The creation of a new agency with a broad mandate for "security" allowed the president to take advantage of bureaucratic resources at his disposal for sensitive projects that commanded the president's attention and would have been more difficult to control or hide within established bureaucracies subject to significant monitoring from interest groups and Congress. For instance, the biological weapons research activity conducted by the FSA was by its nature politically sensitive and was paid for with White House funds. Placing it in the FSA was later described in a memorandum to the president as justified because of the need for political "cover." George Merck explained in a speech just a few years after the war:

In the fall of 1941, opinion in the United States regarding the value of Biological Warfare was by no means united. But common prudence dictated to those responsible for the nation's defense that they give serious consideration to the dangers of possible attack .... Starting as a project under the most extreme secrecy, the work was undertaken under the wing (and cloak) of the Federal Security Agency. Emerging from this "cover" (but not from secrecy) the Army, with the Navy collaborating, took

302 See Internal White House Memorandum, Reorganization (cited in note 288).

303 Letter from George B. Merck to Paul V. McNutt, Federal Security Administrator (Apr 11, 1944), available at National Archives, War Research Service Files, Entry 5A, Box 11. 
over. Unique facilities were built by the Chemical Warfare Service and by the Navy for experimentation on pathogenic agents. ${ }^{304}$

Neither these divisions in opinion nor the fact that the US government had signed a treaty against biological weapons stopped the White House from fomenting such research, however. ${ }^{305}$ In the years that the WRS operated from the bowels of the FSA, the White House managed to funnel millions of dollars into secret-and highly controversial-biological and chemical weapons research. Eventually, once the work of the WRS had matured, political appointees at the War Department and the FSA agreed to recommend that the president transfer many of its functions to the War Department. ${ }^{306}$ The 1944 joint memorandum moving many WRS functions to the War Department written in 1944 admits not only that the FSA was doing both offensive and defensive weapons research, but that these functions were initially placed at FSA for political cover. ${ }^{307}$ The extent of Nazi atrocities in the interim period may have made it less politically important for the president to seek political cover by the end of 1944 for these secret activities. Conversely, by then the organizational and research capacity of the War Department had expanded substantially, making it potentially less important to keep these functions at the new FSA bureaucracy. ${ }^{306}$

Nonetheless, the FSA continued to engage in biological and chemical weapons research even after the transfer of the WRS to the War Department. And by the war's end, Merck proudly proclaimed that he considered the WRS's chief accomplishment to have been

[t]he development of methods and facilities for the mass production of pathogenic microorganisms and their products: First, the microorganisms selected for exhaustive investigation were made as virulent as possible, produced in specially developed culture media under optimum conditions for growth .... In this work it was necessary to determine how well various organisms of high disease-producing power could retain their virulence, and how long they would remain alive under different conditions of storage. ${ }^{309}$

304 George W. Merck, Speech on the Implications of Biological Warfare 3-4 (May 17, 1946), available at National Archives, War Research Service Files, Entry 5A, Box 12.

305 See note 20 for a discussion of the relevant treaty commitments.

306 See Letter from George B. Merck (cited in note 303) (recognizing that McNutt, as FSA administrator, "must be considering some decision" as to what elements of the biological warfare program should be transferred to the War Department).

307 See id (noting Merck's understanding that the War Research Service was placed in the FSA "at first primarily as a political cover for [biological weapons] activities").

308 See id.

309 Merck, Speech on the Implications of Biological Warfare at 3-4 (cited in note 304). 
Nor were the sensitive political functions of the FSA confined to the national defense sphere. Correspondence and newspaper articles suggest Paul McNutt had almost unquenchable presidential aspirations at the time that Roosevelt put him in charge of the largest of the new agencies he created using his reorganization authority. McNutt's biography uncannily foreshadows that of another ambitious heartland governor who attained the White House a half century later: William Jefferson Clinton. Like the Arkansan Clinton, McNutt grew up in a heartland state, attended an Ivy League law school, began his career as a law professor, and continued it as a governor. ${ }^{310}$ Also like Clinton, McNutt's gift of effortless articulation and his record as a moderate Democratic governor soon earned him a national following-and a few committed enemies eager to sabotage his presidential ambitions. ${ }^{311}$

Even before McNutt left for his Philippines post in 1937, it appears that "he was thinking of the Presidency in 1940." mer of 1939, some columnists were suggesting that there were "just two genuine, gilt-edge candidates for the Democratic Presidential nomination in 1940-President Roosevelt and his newly appointed Federal Security Administrator.", ${ }^{313}$ Yet the new agency gave the president a major new slot to deploy-large enough to entice his potential rival for the nomination while requiring sufficiently close collaboration and subjecting the new FSA administrator to enough supervision that it would allow the president to minimize McNutt's ability to act independently. The point was not lost on some observers in the press:

Despite his disclaimers, President Roosevelt cannot put a stop to the reading of political significance into the surprising appointment of Paul V. McNutt to head the new Federal Security Agency .... In most quarters, the feeling is growing that McNutt, no matter how canny he may have been in the past, was neatly taken in by the White House. He is, to veteran interpreters, right behind the eight ball. Outside the official circle, he could campaign freely, walking a tightrope if necessary, criticizing unpopular New Deal policies and Presidential actions .... It will be hard for him to come out next year with convincing statements that he did not approve of things which happened while he was in Mr. Roosevelt's good graces. If the President wants to deflate the McNutt boom,

310 See Blake, Paul V. McNutt at xi-xii (cited in note 108).

311 See id at 227-92 (discussing the efforts of McNutt's enemies, most notably Postmaster General Farley, to derail McNutt's chances for the presidential or vice presidential nomination).

312 Id at 173 (explaining how McNutt's presidential aspirations influenced his decision to accept the appointment as high commissioner of the Philippines). 1939).

313 Id at 238, quoting Daniel Kidney, Hoosiers in Washington, Indianapolis Times (July 15, 
the appointment was a brilliant stroke. Coordinating the far-flung social ventures of the Federal government will be a man-sized job, with plenty of chances for error and bungling .... Of course, there still is the chance the White House wants to look him over at close range, with a view to making him the crown prince or the President's running mate on a third-term ticket. But this gamble seems exceedingly risky to individuals who have kept a constant watch on the political machinations of the Chief Executive and the palace clique. The consensus is that McNutt's ambition overreached itself.

Such risks could hardly have escaped McNutt. But the former governor was nonetheless inveigled by the challenge of running the new superdepartment and encouraged to accept it by his friend, General Douglas MacArthur. ${ }^{315}$

If the FSA proved useful in carrying out secret weapons development projects and co-opting the ambition of a potential rival, why would a president not have been able to achieve these goals without creating the FSA? Although the White House also supported military research at the War and Navy Departments, it anticipated some of the challenges presidents have faced repeatedly in the decades since: the military is both difficult to control and capable of severely damaging policies that prove controversial among the armed services. ${ }^{316}$ Biological weapons research was controversial in the military. In contrast, the White House could benefit by creating an agency with a range of functions in order to provide a measure of cover facilitating certain defenserelated work. While the agency was trumpeting its relevance to national security, it was not publicly announcing its role in offensive biological weapons research, allowing civilian scientists and the universities where they worked relative anonymity. New bureaucratic offices-not characterized by close relationships to existing legislative committees-could administer programs secretly by expending White House funds. Finally, perhaps the president could even benefit from having an additional

314 Has the Wily Mr. McNutt of Indiana Been "Taken In" by Wilier Mr. Roosevelt?, LA Times A5 (July 16, 1939).

315 See Blake, Paul V. McNutt at 230 (cited in note 108) (relating how MacArthur told McNutt that the position would improve McNutt's position with the New Dealers yet maintain the "support of those who recognize the conservative caution of [McNutt's] liberalism"). Despite the aforementioned risks, from McNutt's perspective, the FSA post may nonetheless have appeared as a fine perch from which to mount a presidential campaign if Roosevelt chose not to run. If the president did choose to pursue a third term, McNutt seemed to think that the FSA would be a suitable vehicle for his work while furnishing him a chance to compete for the Vice Presidency.

316 See David Luban, On the Commander in Chief Power, 81 S Cal L Rev 477, 534-35 (2008) (discussing various examples of military leaders inserting themselves into political or policy debates that would traditionally be decided by the commander-in-chief or Congress). 
high-level position to bestow on an ambitious individual such as McNutt, harnessing his ambition to the fate of the new agency and possibly transforming a potential political rival into a supporter without having to reshuffle his existing cabinet.

5. Why Congress allowed greater presidential control when it had fought White House growth.

Why did congressional majorities in 1939 allow Roosevelt to undertake a reorganization that enhanced his power when they had denied him such powers in 1938 and before? Recall that the Reorganization Act of 1939 was a compromise saddled with a two-house veto and a coterie of limits on presidential power over nearly all independent commissions $^{317}$ - perhaps one the median legislator believed would yield somewhat less authority than the president actually exploited. Even supporters of the president had initially balked at giving FDR all the powers he had first sought in the 1938 reorganization bill, in part because critical organized interests-including veterans and doctors working through the AMA - strenuously objected to some aspects of the bill. ${ }^{318}$

In contrast, the new reorganization bill included sunset provisions, statutory limits on what reorganizations could be proposed, provisions for a two-house congressional veto, and reporting requirements facilitating legislative policing of reorganization plans. ${ }^{319}$ The president was supposed to be limited to reorganizations that were justifiable on financial grounds, but he made something of a mockery of that statutory requirement. The final reorganization bill also preserved preexisting legislative compromises protecting independent commissions by exempting many of them from reorganization.

Finally, some members of the legislative coalition supporting reorganization authority were almost certainly concerned about the fate of certain administrative or regulatory programs and may have been quite happy to have the president gain some authority to more effectively shield these from subsequent legislative encroachment. This last category of legislators, in particular, may have been reacting to new information revealed in the 1938 elections, where the New Deal coalition was further eroded by the arrival of eighty congressional Republicans. With the New Deal majority eroding, legislators who might have preferred expansive regulation (subject to legislative control)

317 See text accompanying notes $82-103$ for a discussion of the changes in reorganization legislative proposals between 1938 and 1939.

318 See text accompanying notes $82-87$.

319 See text accompanying notes $98-103$.

320 See note 100 . 
may have opted for vesting greater power in the president, hoping that such power would be used to create the bureaucratic structures that would protect the agencies from subsequent encroachment by a more hostile Congress.

To summarize: a key dimension of the FSA's trajectory involves the president's strategy in the time leading up to World War II to use its creation as a vehicle for asserting greater political control over bureaucratic functions. Although this goal was repeatedly camouflaged amid discussions of strengthening national security and promoting efficiency through reorganization, the control-related aspects of the reorganization were not lost on Congress or the press. Though it is understandable that newspaper accounts of the FSA's creation would emphasize presidential control as much as anodyne efficiency goals, it is worth recognizing that such efforts to enhance White House control do not necessarily culminate in an emaciated agency with little power to resist external political interference. On the contrary: in the FSA's case, the shorterterm policy goals pursued by the Roosevelt administration (and subsequently, the Truman administration) also coincided with the strategies that would enhance the agency's policymaking capacity-and even a measure of its bureaucratic autonomy-in subsequent years.

While this account emphasizes the ways in which structural changes could further presidential control and objectives through the building of presidential capacity, it is not meant to suggest that the White House was devoid of congressional allies in this process. In at least a limited sense, legislative majorities ratified Roosevelt's initial choices by conferring on him a limited authority to reorganize the government and by not vetoing his initial changes. But even at the risk of unduly minimizing the legislature's crucial role, the building of bureaucratic capacity here still seems best understood as a vehicle for enhancing presidential control. The president had the preeminent role in forging the legislative coalition supporting reorganization and tracing the path of different bundles of legal responsibility across the government's elaborate preexisting jurisdictional lines. ${ }^{322}$ The capacities engineered within the bureau-

321 See Polenberg, Reorganizing Roosevelt's Government at 186 (cited in note 22). See also Leuchtenburg, Franklin D. Roosevelt and the New Deal at 271-74 (cited in note 27) (describing how the 1938 elections strengthened a "Republican-conservative Democratic coalition" that began "aggressively to dismantle the New Deal").

322 See Internal White House Memorandum, Other Reorganization Proposals (cited in note 293) (explaining that Roosevelt's "[p]encil notes indicate [ ] action" on the proposals presented by the Bureau of the Budget Staff). 
cracy, including the capability to undertake sensitive projects using White House funds and the cadre of legal and political superiors foisted on bureaus, seem especially suited to serve presidential needs. ${ }^{33}$

Some might still insist on examining the FSA's history through a theoretical lens focused on congressional power. In that account, congressional majorities would be seen as achieving their goal of protecting domestic agencies at a time when war was growing increasingly likely and Roosevelt's political fortunes were declining. Even so, that story is one where the legislative majority sought to achieve goals by strengthening presidential power and where the end result was not a contribution to maintaining the status quo but the setting in motion of a process that further grew the resources available to the FSA's bureaus as well as their underlying legal powers. ${ }^{324}$

\section{B. Enhancing Political Coalitions}

Another implication of the FSA's creation emerges if we focus not only on how its creation affected the internal workings of the executive branch, but on how it affected the external relationships of the administration. It may not seem remarkable to observe that the FSA's creation allowed the administration to engage in an epistemic process of "framing" policy priorities by emphasizing their role in achieving the widely desired goal of "security." While it is common for political and legal observers to talk about the impact of reframing, the term has multiple meanings. In addition, it is not obvious how or why reframing can change the political prospects for the implementation of a certain law. ${ }^{325}$

The Roosevelt administration's determination to identify the FSA with the concept of security involves a different type of framing. One

323 See Bureau of the Budget Staff, Recommendations for Interdepartmental Transfers (cited in note 293) (identifying, by cabinet agency, bureaus for Roosevelt to transfer).

324 Given these details, the burden should be on those emphasizing congressional dominance or shared responsibility to further document the extent to which the legislature anticipated and stage-managed a process that seems now, even upon close inspection, to have been centrally forged by a White House that sought and gained sufficient legislative support for its own goals. For an interesting discussion emphasizing the centrality of the legislative role, see Barry R. Weingast, Bureaucratic Discretion or Congressional Control? Regulatory Policy-making by the Federal Trade Commission, $91 \mathrm{~J}$ Polit Econ 765, 771-74 (1983).

325 Some discussions of framing effects involve perceptions of utility associated with gains and losses, and they have been extensively analyzed in the context of individual decisionmaking. A legion of articles discuss framing effects in the cognitive, prospect-theory sense. The seminal work is Daniel Kahneman and Amos Tversky, Prospect Theory: An Analysis of Decisions under Risk, 47 Econometrica 263, 286-88 (1979) (developing a model for how people use "reference points" to make decisions and how a shift in this reference point can influence behavior). Other versions of the idea focus on the introduction of new dimensions of political competition to complicate, disrupt, and potentially realign existing coalitions. See William H. Riker, The An of Political Manipulation 10-17 (1986) (discussing the effect of introducing new configurations into political battles). 
advantage of considering that "framing" process in a specific context is that it becomes possible to make more fine-grained observations of how the reorganization could have had an epistemic, or "framing," effect on politics. In particular, developments regarding the FSA suggest the importance of two specific mechanisms-identified earlier in our discussion of refining existing theories - through which the blurring of the security concept could enhance the FSA's prospects: one involves shaping the perceptions of the mass public about the meaning of security; the other involves the separate enlargement of legislative coalitions supporting agency functions by ambiguating the extent to which a vote for the FSA also constitutes a vote for national security or war-related efforts.

Both of these strategies depend heavily on demonstrating to legislators, organized interests, and the public at large that the legal mandates the FSA was implementing were inextricably connected to national defense and the war effort. Regardless of whether the Roosevelt administration wanted to enter the war at the time the FSA was created, the White House was increasingly cognizant of a foreign policy crisis that could further complicate its domestic political goals. As one historian observed recently, it was by March 15,1939-just over a month before the reorganization creating the FSA was publicly proclaimed-that "foreign affairs achieved the absolute dominance over domestic affairs that they were destined ever after to retain in [Roosevelt's] mind., ${ }^{326}$ The impending foreign policy problems made the president increasingly anticipate that the nation could find itself embroiled in war:

The experience was, for him, not dissimilar in some essentials to that of the spring of 1933 when, amid universal ruin and collapse, he had presided over the birth of the New Deal .... ("Never in my life have I seen things moving in the world with more cross currents or greater velocity," he wrote in a personal letter on March $25,1939)$.

Nor was the president alone, as some legislators increasingly favored repealing federal neutrality laws to facilitate American involvement in the European theater ${ }^{328}$

The administration's goal of emphasizing the connection between the work of the FSA and national defense became easier to achieve because of the importance to the military of the new agency's activities. The FSA's functions not only contributed to an expansive concep-

326 Davis, $F D R$ at 423 (cited in note 10) (explaining that Hitler's invasion of the Czech Republic in violation of the Munich Agreement was a watershed event in Roosevelt's mind).

327 Id at 429.

328 Id at 427 (discussing Senator Key Pittman's abortive introduction of a "neutrality bill" that responded to Roosevelt's concerns regarding Hitler's actions). 
tion of security that encompassed ordinary health, education, and public welfare activities, but also served ends specifically connected to domestic and international security in the conventional sense. These included the relocation of Japanese-Americans, technical assistance to law enforcement agencies engaged in police work against juvenile delinquents, the aforementioned research programs in biological weapons and related areas, an antiprostitution enforcement program designed particularly to protect the armed forces, and the development of disaster assistance programs to be deployed in case of war-related attacks against civilians. In addition, the FSA emphasized the defenserelated import of a host of other activities, ranging from vocational education to nutrition. Together, these presidentially driven choices afforded the administration with an opportunity to affect how the public understood the concept of security and how legislators understood the payoffs of supporting the FSA as the nation prepared for war. ${ }^{329}$

\section{Shaping public perceptions of the meaning of "security."}

Following the merger, FSA officials endeavored to present the public with information about the blending of national security and domestic administrative, regulatory, and social welfare functions. Speeches in 1939 and 1940, such as the following statement Paul McNutt made to college students in Lakeland, Florida, set the stage for future appeals:

The formation of the Federal Security Agency, mobilizing as it does, the Government's technical facilities for coordinated action, represents a first stage in the campaign against insecurity and want, but the battle is not yet won. Here, as elsewhere, in the conflict with the enemies of democracy, vigilance and courage are necessary at all times, for here, if not elsewhere, America cannot afford to wage a defensive war. We have assumed and must retain the offensive.

In television programs and live speeches, McNutt unrelentingly alluded to the "enemies of democracy" and the need to quicken the pace of efforts against "insecurity and want" so that the nation would better be able to face its adversaries. ${ }^{331}$ So pointed was McNutt's war-focused rhetoric at a time when public and legislative opinion was still largely isolationist that the White House received correspondence criticizing

329 See Part I.D for greater detail on the FSA's war-related programs.

330 Address by the Honorable Paul V. McNutt, Federal Security Administrator, to Congress on Education for Democracy, Florida Southern College, Lakeland, Fla 3 (Nov 12, 1939), available at Franklin D. Roosevelt Presidential Library, Papers of Richard V. Gilbert, Speeches on the Federal Security Agency by Paul V. McNutt, Box 18 (emphasis added) (stressing the analogy between ordinary war and the domestic fight against "insecurity and want").

331 See, for example, id. 
"the jingoism of Paul McNutt over NBC last Saturday evening. He is doing his best to defeat the excellent leadership for peace you are so nobly exercising., ${ }^{, 32}$ Yet the White House joined McNutt and his aidesparticularly by mid-1940-in issuing statements linking national defense to "preparedness" on the home front. On June 12, in response to a request from Senator Claude Pepper for a message "on national defense," the president indicated to the National Convention of Townsend Clubs, meeting in St Louis, that "we have mobilized our industrial resources to meet pressing conditions confronting us and assure[d them] that the Government has no intention of neglecting the other phase of preparedness, namely continued improvement of social, economic, and moral structures of American life., ${ }^{, 333}$ Statements such as these echoed the content of the presidential reorganization message accompanying the executive order that created the FSA, thus reinforcing the president's message.

Over time, that message appears to have contributed in subtle but material ways to how the agency was perceived in the public sphere. In the process, the White House and Roosevelt administration officials used the creation of the FSA as part of an effort to shape public perceptions, particularly of the meaning of "security." They sought to broaden the scope of the term to place social, economic, and health-related security on par with traditional definitions of national security, and they sought to emphasize the interconnections between national security and security involving public health, economic, and social guarantees. There was by the time of the FSA's creation widespread familiarity with the Roosevelt administration's tendency to describe social and economic challenges as akin to war, and historians since then have widely acknowledged this pattern. ${ }^{334}$ But the realignment of health, education, and security functions within the FSA, and the circumstances immediately following this realignment, show how government officials directly sought to blur the distinction between national, economic, and social security at the level of organizational structure and bureaucratic

332 Letter from Franklin P. Cole, Minister of Williston Congregational Church, to President Roosevelt (Jan 13, 1940), available at Franklin D. Roosevelt Presidential Library, Federal Security Agency, 1940 Folder, Official File 3700 (protesting McNutt's emphasis on the need for warrelated preparation and the work of the FSA in promoting this).

333 Internal White House Memorandum, Summary of Correspondence from Lowell Mellett (circa June 12,1940, original correspondence June 5, 1940), available at Franklin D. Roosevelt Presidential Library, Federal Security Agency, 1940 Folder, Official File 3700 (paraphrasing the president's message to a civil society event, and demonstrating McNutt's involvement in helping to craft a message from the president emphasizing the role of the FSA in defense).

334 Regarding Roosevelt's analogies to war, see Leuchtenburg, The FDR Years at 46-54 (cited in note 50) (showing just how deeply the theme of war was enmeshed in FDR's 1932 presidential campaign). 
mandate. This dimension of the FSA's trajectory included efforts to justify the FSA's creation in terms of strengthening national capacity to counter brutal dictatorships, deployment of FSA resources to support the war effort, and public communications emphasizing the FSA's national defense role. ${ }^{335}$

The determination of the White House and the FSA's leadership to identify the new agency with national security and defense emerged almost immediately upon its creation. Within less than one year of its creation, the agency issued a report chronicling its activities. ${ }^{3.6}$ The report provides a revealing picture of the agency's aggressive focus on activities related to national security. The SSB, for example, had engendered a program to organize the massive movement of workers-some of whom were unemployed and others who sought more desirable jobs - toward defense-related industries. ${ }^{377}$ The SSB had over a thousand offices nationwide, a national system for keeping records of employees, and a mission that broadly encompassed the provision of assistance to individuals seeking work. ${ }^{338}$ Increasingly, the SSB achieved its employment-related goals through grants to states, allowing it to graft the state bureaucracies onto its growing administrative structure. These characteristics made the SSB a useful vehicle in lubricating the massive defense-related reallocation of labor already afoot by 1940 . This is how one agency report to congressional staff put it:

[T]he Board's Bureau of Employment Security was directing, through the 1,500 local offices of the United States Employment Service, efforts to insure orderly redeployment of the existing labor supply and more effective placement of workers already employed. Procedures for obtaining more current information needed for recruiting workers through the local employment offices were also put into effect. In June 1940, $\$ 2,000,000$ was appropriated for the use of the Social Security Board in providing special Federal assistance to, and supervision of, State employment services for

335 With respect to the FSA's priorities, see Federal Security Agency, First Annual Report of the Federal Security Administrator at 7 (cited in note 126); Federal Security Agency, Second Annual Report at 1 (cited in note 126); Federal Security Agency, Annual Reports for the Fiscal Years 1941-1942, 1942-1943 at v-vi (cited in note 126); Federal Security Agency, Annual Report for the Fücal Year 1944 at ix (cited in note 126); Federal Security Agency, Annual Report of the Federal Security Agency for the Fiscal Year 1945 at 1-10, 184-88, 464-66 (cited in note 126); Federal Security Agency, Annual Report of the Federal Security Agency, For the Fiscal Year 194672 (GPO 1947).

336 See Federal Security Agency, First Annual Report of the Federal Security Administrator at 7 (cited in note 126).

337 See id at 50 .

338 See id at $44-47$

339 See id at 47. 
the selection, testing, and placement of defense workers in occupations essential to national defense. ${ }^{300}$

While the SSB was busy funneling workers into defense-related industries and helping the states develop administrative systems to do the same, the rest of the FSA was also in the process of forging defenserelated capacities. In contrast to the SSB, many of the other bureaus folded into the FSA lacked a dense, nationwide network of offices or a copious nationwide recordkeeping system. Nonetheless, the fledgling new agency emphasized how its bureaus were aggressively contributing to the national defense:

In the last month of the fiscal year the Congress appropriated the sum of $\$ 15,000,000$ for the vocational education of defense workers. The appropriation act provided that the program was to be carried out under plans submitted by agencies of the several States and approved by the Commissioner of Education. It was specified that the plans must include courses supplementary to employment in occupations essential to the national defense and preemployment refresher courses for workers, selected from the public employment office registers, preparing for such occupations. The Office of Education immediately began to set in motion the machinery for carrying out the purposes of these appropriations.

At the same time, the Public Health Service was in consultation with the Council of National Defense for the purpose of formulating plans for advising the Council regarding the health and medi$\mathrm{cal}$ aspects of national defense and to coordinate health and medical activities affecting it. The Public Health Service was also laying the groundwork for a program allied to defense to promote the health and improve the physical fitness of out-of-school young people employed on projects administered by the National Youth Administration.

The National Institute of Health at the request of the Navy Department was also conducting studies of physiological problems connected with high altitude flying and rapid decompression. Both Army and Navy authorities were advised on standard immunization procedures for the military forces. Cooperation of the International Health Division of the Rockefeller Foundation was secured in the manufacture of 150,000 doses of yellow fever vaccine. Plans have been made for the continued production on a

340 Federal Security Agency, First Annual Report of the Federal Security Administrator at 7 (cited in note 126). 
large scale of this vaccine at the Rocky Mountain Laboratory, Hamilton, [Montana]. ${ }^{341}$

These descriptions emphasize not only the speed with which the FSA's units sought to create a perception among the public of their roles in defense efforts, but also the extent to which the young agency had begun convincing Congress to appropriate resources to fund the agency's defense-related activities. Over time, the perceptions the agency fomented in Congress contributed to the creation of a bureaucratic reality wherein significant policy innovation increasingly blurred the distinctions between national security and social or economic security. ${ }^{32}$

The agency's own employees were still another audience for senior officials' emphasis on defense-related efforts. Periodically, the FSA administrator's office would convene conferences to review the agency's progress in defense-related pursuits. The Office of Community War Services (CWS), focused on providing health and welfare services to military and civilian individuals in areas surrounding military establishments, was the hub of such conferences. Documents such as the following conference agenda conveyed to employees one of the critical missions the FSA now prioritized:

For over three years, CWS has been concerned with the provision of adequate health, welfare, and related community services to the citizens of the Nation during the period of the war emergency-particularly in critical war production centers and in centers adjacent to military establishments. It is the purpose of this conference to review our past achievement, to analyze critically our present direction, and to plan together further accomplishment. ${ }^{\text {43 }}$

The extent of the FSA's identification with war and national security left its mark in the long term. Eventually, some of the most explicitly militarized or national security-related functions of the FSA were shut down, including the quasi-military Civilian Conservation Corps, the War Research Service, the operations to facilitate relocation of JapaneseAmericans, and the Office of Community War Services. At the same time, a substantial cluster of defense-related research projects continued. ${ }^{34}$ The Truman administration allowed George Merck to announce

341 Id at 7-8 (detailing the rapid expansion of the FSA's war-related institutional capacity).

342 See Part I.D.

343 Federal Security Agency, Community War Services, Agenda and Folder of Reference Material, Conference of Regional Directors and Assistant Regional Directors 1 (Feb 12, 1944), available at National Archives, Watson Miller Archive, Federal Security Agency, Community War Services Folder, Entry 10, Box 1.

344 See Office of the Federal Register, United States Government Manual 2001-2002 at 597652, online at http://frwebgate.access.gpo.gov/cgi-bin/getdoc.cgi?dbname=2001_government_ manual\&docid=188578tx_xxx-112.pdf (visited Apr 14,2009) (listing these agencies in an Appen- 
publicly the FSA's success in building for the country a viable biological weapons capacity. An article in The New York Times described the disclosures in May of 1946:

While the physicists spoke on the bomb, a biologist, George W. Merck, of Merck \& Co, pharmaceutical house, exemplified the peculiar duality of modern science by discussing more horrors to come in the field of biological sciences. In a review of work done in the field during the war, Mr. Merck discussed American achievements both in the production of disease for large-scale use as a weapon and in defenses against enemy-sent disease. Like all reports on this subject made to date, Mr. Merck's remarks were clothed in a security-forced vagueness. Discussing the matter of security, however, he assured his hearers that, should the needs of humanity call for release of any information so far withheld, the Army would at once release it. One of his more interesting revelations was the discovery by biologists of a new chemical agent on living plants. This agent, of which the identity was not revealed, may be spread on enemy farmlands. The enemy then cultivates and works his farm, and everything appears normal. Only when harvest time comes does he discover that his months of work have beenliterally-fruitless. His garden and field crops have borne no fruit, for just before harvest time their roots have withered away and they cannot yield. ${ }^{345}$

Continuing agency involvement in defense-related activities dovetailed nicely with Eisenhower's choice when appointing the first secretary of HEW, the FSA's successor agency. Oveta Hobby was chosen for the post. Her principal experience before being entrusted with the mammoth cabinet agency was running the Women's Army Corps. ${ }^{366}$ Even to this day, the commissioned corps of the Public Health Service retains a quasi-military organizational structure and wears correspondingly martial uniforms. The Centers for Disease Control retains the preeminent operational role in responding to deliberately promoted or natural outbreaks of infectious diseases, and the NIH continues to engage in substantial research activities funded by or related to military mandates. ${ }^{347}$

The administration's persistence in broadening the scope of security by discussing national defense suggests several realities. First, the

dix titled, "Federal Executive Agencies Terminated, Transferred, or Changed in Name Subsequent to March 4, 1933").

345 NY Times (May 18, 1946), available at National Archives, War Research Service Files, Entry 5A, Box 12 (emphasis added) (reporting on Merck's speech at the Westinghouse symposium in Pittsburgh revealing the FSA's wartime biological warfare research program).

346 See Miles, The Department of Health, Education, and Welfare at 25-26 (cited in note 13).

347 Mullan, Plagues and Politics at 207 (cited in note 13). 
administration emphasized the existence of another dimension to the political choices associated with FSA bureaus. ${ }^{348}$ In response, some public constituencies already concerned about defense-like the editorial writers that shaped the public discourse-likely found themselves more drawn to supporting the bureaus than they would have been otherwise. ${ }^{39} \mathrm{~A}$ few may even have found resonance in the idea that security was a concept that extended (if not seamlessly, then at least malleably) from strengthening military capacity to boosting the nation's resilience in the face of adversity. Whether that adversity came from economic dislocation or military disaster mattered less, in this conception, than whether the government had built the administrative capacity to assist citizens in responding to crises. Second, there were some voters who lacked - then as now - the sophistication, time, and political knowledge to form elaborate opinions about the proper scope of "security." For them, the determination of the administration and the FSA to identify the agency with national security efforts suggests something else. Perhaps the agency's identification with the symbols of national power sufficiently reinforced the administration's political rhetoric, translating into longer-term support of broad policy prescriptions. At a time when the administration was also seeking to broaden support for a potential US role in the international conflict, Roosevelt probably also gained some political rewards by conveying a sense of urgency about looming international threats. Even progressives concerned with the erosion of New Deal programs could be reassured that budgetary and administrative initiatives to expand national defense would not necessarily erode New Deal goals. ${ }^{350}$ As the war progressed and the agency's responsibilities grew, so too did the support these members of the mass public were willing to provide for the idea that the FSA's assortment of bureaus should become the newest cabinet-level department of the federal government.

While these dynamics help explain the importance the White House and the FSA officials assigned to promoting their conception of national security, one might question the precise connection between their framing strategy and the bureaucratic changes that wrought the FSA. Perhaps the White House could have argued that nutrition, physical education, social insurance, and medical research were essential to national security even without acquiring reorganization authority, or using

348 See Miles, The Department of Health, Education, and Welfare at 18 (cited in note 13). See also Dennis Chong and James N. Druckman, Framing Public Opinion in Competitive Democracies, 101 Am Polit Sci Rev 637,638 (2007) (analyzing how public opinion in a democracy is affected when "elites" frame their proposals around particular frames of references).

349 See id at 651.

350 See Polenberg, War and Society at 73 (cited in note 114). 
it to create the FSA. But the bureaucratic changes seem to have enhanced the administration's position in pursuing its distinctive security agenda. The creation of the agency generated considerable media attention, giving the administration a chance to ply its version of security. The FSA increased the bureaucratic capacity at the White House's disposal that could help make a case to the public that the FSA's programs were contributing both to national defense as well as to the expansive conception of security that encompassed both war-related and domestic regulatory activity. ${ }^{351}$ Paul McNutt, imbued with the singular authority of the "FSA administrator" traveled the country discussing his agency's role in promoting its particular brand of "national security.",35

When he was not giving speeches, McNutt could join his aides in managing the bureaus' new relationships with constituencies within the government. Serving wartime and national security needs while expanding domestic functions required political engagement from top agency administrators who could curry favor with legislators, other federal government officials, and the mass public. This was unlikely to be available to the agencies that represented the federal government's health, social welfare, regulatory, and educational capacity if they had remained scattered throughout government. Treasury and Agriculture secretaries had more pressing demands than building up the FDA or the PHS. The dynamic the White House faced therefore suggests that bureaucratic changes could make a difference, even if individual bureaus would have sought-on their own-to refocus some of their work on defense-related activities as the war approached. In contrast, fragmentation of health, social welfare, education, and regulatory capacity could have strengthened arguments for meeting wartime needs by developing exclusively military-or temporarily war-focusedprograms. Such moves would have placed the future of many health and welfare initiatives in doubt after the war.

In some respects, the FSA was not alone. The efforts of its top officials to emphasize the centrality of its work for national defense represented an administration-wide move to emphasize the importance of defense as international conflict became more likely. Yet the rhetoric emanating from the FSA appears more pronounced than what was emerging from other agencies (with the occasional exception of the Agriculture Department, whose budget followed a similar trajectory to that of the FSA in some years). The FSA appears to have differed from

351 See Part I.A. See also notes 330-333 and accompanying text.

352 See the text accompanying notes 330-333 for more on Paul McNutt's travel and lobbying. See also Paul V. McNutt, Using Our Heads 73 (unpublished book manuscript, Apr 4, 1940), available at Franklin D. Roosevelt Presidential Library, President's Personal File 2836 (Paul McNutt) (referring to social security as part of "national security"). 
other major domestic administrative and regulatory agencies such as the Agriculture and Interior Departments, from which some of its major bureaus were drawn, and the sister agencies created by reorganization (the Federal Works Agency and the Federal Loan Agency) in two ways: by having a greater concentration of actual defense-related activities $^{333}$ and by repeatedly emphasizing how even the work it was performing that was not explicitly related to defense was nonetheless integral to a broad and conceptually coherent version of the concept of security. To take just one example, the FSA's summaries of its annual activities between 1940 and 1942 mentioned war, emergency, and national defense more often on average than did other major domestic agencies' summaries. ${ }^{3.4}$ The agency's national security focus is starker still in the headings of some annual reports, which emphasize the bureaus' war-related activities and describe the agency's goal of providing "Security for America. ${ }^{, 355}$ If anything, the tendency of the FSA administrator to promote an expansive conception of the security trope and specifically to link the FSA's work to national defense continued even more aggressively under the leadership of Oscar Ewing in the Truman administration. ${ }^{36}$

It should also be noted, however, that the precise implications of linking domestic administrative and regulatory programs to security depends heavily on whether the underlying concept of security is defined broadly or narrowly, which in turn depends considerably on presidential choices. Thus, while associating the domestic administrative and regulatory functions of the FSA with the concept of security appears to have enhanced their budgets and political support, a different scenario seems to have emerged with the recent creation of DHS. In that case, the president used a similar political opening to shift resources away from the "legacy" mandates of domestic and regulatory agencies rather

353 For detail regarding the FSA's defense-related activities, see, for example, Bureau of Public Inquiries, United States Government Manual, Fall 1942 at $390-92$ (cited in note 82) (presenting organizational charts of the individual agencies and listing war-related bureaus).

354 Distinctions in the type of war-related rhetoric in the agencies' annual reports are apparent from how the reports discuss individual bureau activities, as well as the frequency with which report summaries (providing an overview of agency activities) mention war or national defense. Though all of these agencies were pervasively emphasizing war-related activity by 1943 , the FSA's particular interest in these matters is apparent in its more aggressive use of defenserelated rhetoric between 1940 and 1942 . As calculated by the author, the ratio of the incidence of the terms "war," "conflict," and "defense" per page in the FSA Annual Report's summary was" nearly 0.5 in 1940 , just under 0.2 in 1941, and about 0.33 in 1942. By comparison, the figures for the FWA were $0.25,0.1$, and 0.12 respectively and were far lower for Interior and Agriculture. See generally Federal Security Agency, First Annual Report of the Federal Security Administrator (cited in note 126); Federal Security Agency, Second Annual Report (cited in note 126); Federal Security Agency, Annual Reports, For the Fiscal Years 1941-1942, 1942-1943 (cited in note 126).

355 See Federal Security Agency, Second Annual Report at 1 (cited in note 126). See also Part I.D.

356 See Part I.C. 
than expanding them. In situations where actual bureaucratic discretion and statutory mandates give an administration some flexibility to use the new resources, one should expect the administration's political agenda to make a difference. ${ }^{357}$

2. Enlarging legislative coalitions by ambiguating functions.

Apart from shaping public perceptions directly, Roosevelt and his supporters had a lot to gain from emphasizing the connection between national defense and domestic policy initiatives that he favored. Southern Democrats and Republicans who were skeptical of the New Deal were often also quite negative about American participation in international conflicts. But there is some indication that these constituencies in fact favored a strong, vigorous military-both for domestic political reasons and (perhaps) for purposes of deterring international activity that could offend US interests and provoke conflict. ${ }^{388} \mathrm{By}$ ambiguating the distinction between national defense and domestic regulatory efforts, Roosevelt could make it at least possible to galvanize new sources of support for his programs. At the same time, his focus on threats facing the United States when presenting his new superagency to the American public served the purpose of highlighting the relative immediacy of threats facing the nation, even as he also endeavored to convey how he was preparing the structures of government to respond effectively in the face of such threats.

Recall that diminished legislative coalitions were a challenge for FDR during the second phase of the New Deal. Politically, Roosevelt had pushed the envelope in passing expansive new legislation, resulting in the shedding of marginal coalition members. And political support could be adversely affected and further wane with continued defeats. Consider Social Security as an example. From its origins, the program was politically controversial. Though it was relatively popular among Midwestern and Northeastern urban constituencies, it was not universally supported. ${ }^{359}$ In part as a compromise with Southerners, the

357 Even when such flexibility is limited, presidential efforts to bolster an agency's standing may in some circumstances benefit from involving an agency in more politically salient activity. Consider, for example, the Roosevelt administration's efforts to persuade the public through public conferences and presidential statements that nutrition and physical education were components of defense and security. See, for example, note 193. In contrast, the Bush administration sought to persuade legislators and the public that regulatory agencies such as US Customs and the US Coast Guard needed to play a greater role in providing a distinctly narrow conception of national and homeland security-involving primarily protection against terrorist attacks - and that this function contrasted with the agencies' existing priorities associated with their legacy mandates. See Cohen, Cuéllar, and Weingast, 59 Stan L Rev at 725-28 (cited in note 26).

358 See Heinrichs, Threshold of War at 11-12 (cited in note 115).

359 See Derthick, Policymaking for Social Security at 134 (cited in note 225). 
administration settled for a program that entirely excluded the farm sector from coverage. ${ }^{300}$ The importance of conservative Southern Democrats underscores Roosevelt's challenge in expanding constituencies for one of his signature domestic policy efforts. If at all possible, he would have welcomed the chance to build such support among Southerners who were in a position to block the program's functions or future expansion. ${ }^{361}$ Moreover, other things being equal, the outbreak of war was likely to erode support for domestic regulatory and administrative programs unconnected to the war effort. ${ }^{362}$

Finally, a nontrivial group of legislators, including prominent Southern Democrats and Republicans, were more inclined to support national security programs-though not necessarily active participation in international conflicts-than domestic regulatory, administrative, or social welfare programs. ${ }^{3.3}$ Before 1939 , a number of such lawmakers viewed military strength in a different light than New Deal programs. Spurred by editorials and growing constituent concerns about defense, lawmakers showed themselves to be increasingly willing to fund military activities. Even in light of lingering isolationist concern, House and Senate leaders began ramping up military appropriations at the behest

360 See id at 263-64. See also Ira Katznelson, When Affirmative Action Was White 22-23, 43-44, 47-48 (W.W. Norton 2005) (pointing out that "the South's [congressional] representatives built ramparts within ... the New Deal and the Fair Deal to safeguard the region's social organization," in part by excluding "categories of work in which blacks were heavily overrepresented, notably farmworkers and maids").

361 See Derthick, Policymaking for Social Security at 296-97 (cited in note 225) (noting that Roosevelt endorsed disability legislation in his 1942 budget message but did not pursue it due to legislative opposition); Katznelson, When Affirmative Action Was White at 22 (cited in note 360) (explaining that Southerners accomplished their legislative goal of excluding African-Americans from Social Security "by making the most of their disproportionate numbers on committees, by their close acquaintance with legislative rules and procedures, and by exploiting the gap between the intensity of their feeling and the relative indifference of their fellow members of Congress").

362 See Polenberg, War and Society at 74 (cited in note 114) (discussing how preparations for defense absorbed the time and energy of a growing number of government officials).

363 See Leuchtenburg, Franklin D. Roosevelt and the New Deal at 300 (cited in note 27) (pointing out examples of how Congress was aggressively supporting a defense buildup by the middle of 1940). Southern Democrats were increasingly opposed to Roosevelt's social welfare and regulatory agenda. See Polenberg, War and Society at 86 (cited in note 114) (quoting Southern Democrats who believed that some New Deal agencies were controlled by "social gainers, do-gooders, bleeding-hearts and long-hairs ... [with] screwball ideas"). Yet they were viewed as inclined towards internationalism and concern about national defense in the period immediately before World War II. See Alexander DeConde, The South and Isolationism, 24 J S Hist 332, 333 (1958); Virginius Dabney, The South Looks Abroad, Foreign Aff 171, 172-74, 177 (Oct 1940); Malcolm E. Jewell, Evaluating the Decline of Southern Internationalism through Senatorial Roll Call Votes, 21 J Polit 624, 646 (1959) (comparing Southern Democratic senators, who voted in support of Roosevelt's internationally focused fiscal programs 92 percent of the time, with Democratic senators as a whole, who supported these same programs 85 percent of the time). 
of the White House and the military in $1936{ }^{364}$ Against the backdrop of lingering concerns about budget deficits, many lawmakers as early as 1937 were nonetheless "volunteering to help unbalance [the budget] still further by making the sky the limit in appropriations for new naval buildings." ${ }^{\text {,65 }}$ Newspaper editorials openly inveigled Congress to prioritize "the need for a stronger air fleet, a larger navy," and national security at a time when "the Government is spending recklessly for numerous other purposes. ${ }^{366}$ Prominent Southern Democrats and Republicansblocs rarely supportive of the president's domestic agenda-nonetheless lauded the president's criticism of dictatorship and voiced approval for ratcheting up national defense expenditures. ${ }^{367}$ Indeed, by 1939 , lawmakers were increasingly persuaded of the value in increasing their support for defense-related programs while considerable debate persisted about core New Deal programs. ${ }^{368}$

In a world where presidential supporters could exert some influence over budgets and public discussion of federal priorities, the asymmetry in legislative attitudes regarding defense and social welfare posed an opportunity as well as a challenge. Once again, the White House could use reorganization to secure greater support for the bureaucracies entrusted with legal responsibilities that the administration prioritized. By blending national security with health regulation and public benefits, the Roosevelt administration provided legislators who were eager to support national security functions but skeptical about domestic welfare and regulatory programs with a new reason to support bureaus within the FSA. This development was especially important in expanding the extent of political support for administrative bureaus

364 See House Military Bill Sets Peak for Peace Time, Wash Post 2 (Feb 11, 1936) (summarizing a $\$ 389$ million appropriations bill).

365 The American Navy, NY Times 18 (Dec 30,1937).

366 Editorial, To Safeguard Defense, Wash Post 12 (Dec 2,1938).

367 See, for example, Congress Divided on the Message, NY Times 13 (Jan 5, 1939) (referencing Southern Democratic senators' praise of the president's focus on international security problems); Robert C. Albright, Arms to Get Right of Way in Congress, Wash Post 1 (Dec 9, 1938) (referencing Republican senators' support of the president's defense-related recommendations). See also James T. Patterson, A Conservative Coalition Forms in Congress, 1933-1939, 52 J Am Hist 757, 768 n 39 (1966) (noting how Southern Democrats overwhelmingly supported the president in a "key vote" in 1939 to "revise the neutrality law").

368 Summarizing an emerging consensus within official Washington, The New York Times reported:

The totalitarian states ... lead the world in immensity of preparations and in volume of expenditures for war, but the United States, slow to "strain every nerve" in the international race for armaments, has speeded up all her preparations recently and the last session of Congress started her on her way toward one of the greatest peace-time national defense outlays in her history.

Hanson W. Baldwin, Fourteen Billion Dollars a Year: The World's Arms Bill, NY Times 55 (Aug $21,1939)$. 
that conservatives (especially Southern Democrats) would have otherwise been less interested in supporting.

Notice that the FSA's internal activities - not just the public justification of its functions-reflected strong connections to national defense. Biological weapons research was being conducted through the WRS. The SSB was providing special assistance to families impacted by the war. It was also assisting with placement of job seekers in warrelated industries through its employment service. The FSA was training employees for war-related industries through the Office of Education. It was conducting anti-prostitution enforcement through the PHS. Budget increases for the agency during the war years were substantial, and somewhat greater emphasis on war and defense is qualitatively apparent when comparing the FSA's Annual Reports to those of other major domestic agencies, including Interior and Agriculture, from which some of its bureaus were drawn. ${ }^{3.9}$ And years after the war, the focus on defense continued. As Figure 5 indicates, the FSA organizational chart continued to show the presence of an assistant administrator for Defense into the 1950 s, with no comparable positions existing at Interior, Agriculture, or Treasury.

369 For an overview of the FSA's defense-related activities, see Part I.C. For a description of the president and the FSA's strategy for using the WRS, see note 192 and accompanying text. 
FIGURE 5

ORGANIZATIONAL CHART OF THE FEDERAL SECURITY AGENCY DECEMBER 15, 1951

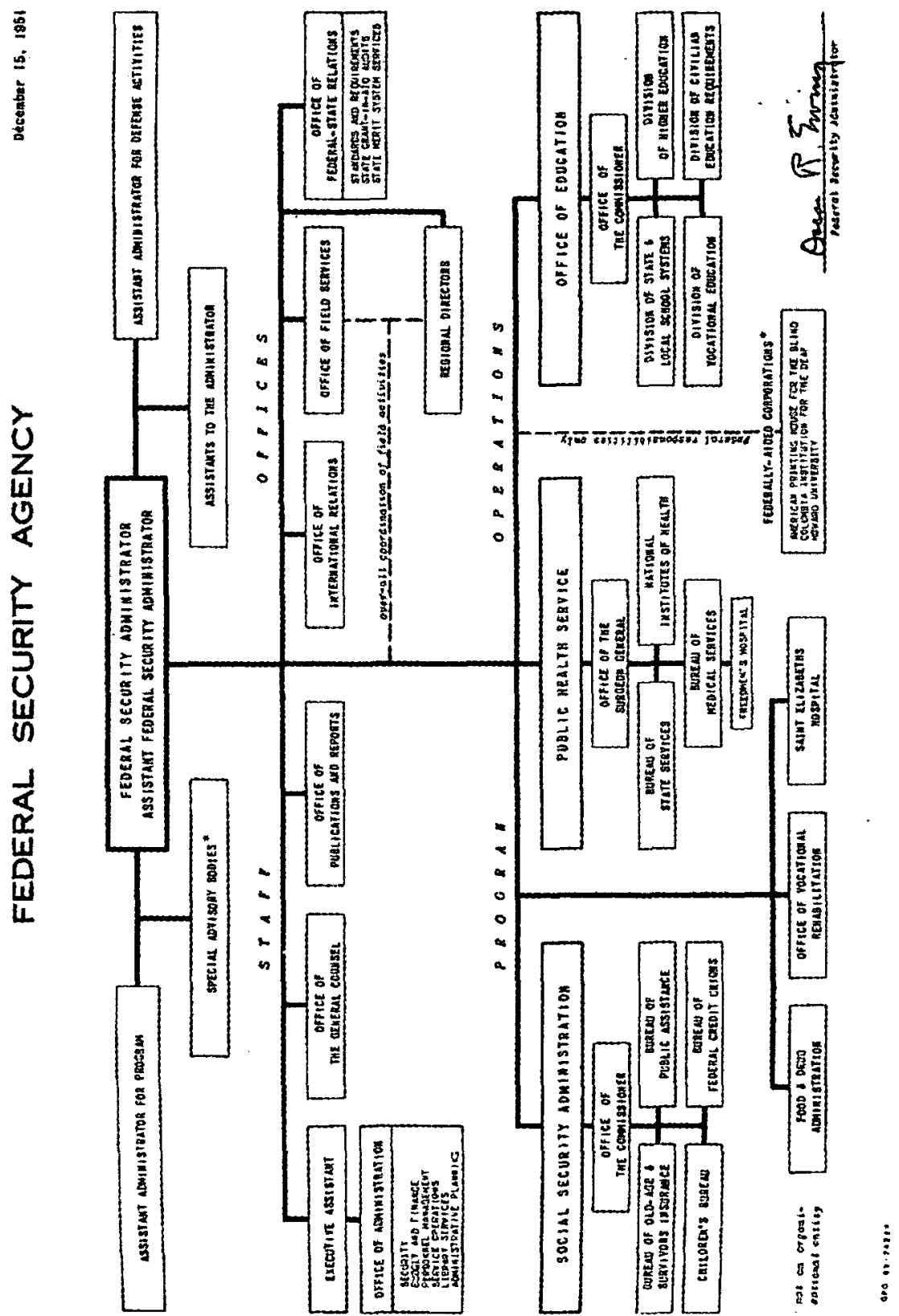

Source: Federal Security Agency, Organizational Charts and Budgets (cited in note 105). 
The Roosevelt administration clearly understood that lawmakers were among the most critical audience for the FSA's national securityrelated work. McNutt had his aides monitor congressional hearings that focused on defense research to ensure that legislators were aware of the FSA's work in areas such as improving the prospects for "high altitude military flights." ${ }^{300}$ Even after the war, FSA staff prepared organizational charts for congressional staff explaining the enlarged scope of the FSA's defense-related activities:

The period of defense preparation and of actual war coincides with the time during which the Federal Security Agency was formed and has been developed. In this emergency because of the very nature of its functions - the safeguarding of health, the fostering of education, and the promotion of social and economic security-the Agency became the center around which numerous war activities were developed. At the very beginning of the Defense Program of 1940, the Federal Security Administrator was named Coordinator of the Office of Health, Welfare, and Related Defense Activities which was established by the Council of National Defense on November 28,1940 for the coordination of all health, medical, welfare, nutrition, education, recreation and other related fields of activity affecting the national defense .... The Council established the Health and Medical Committee ... to advise on health and medical aspects of national defense and to coordinate health and medical activities affecting national defense. With the approval of the President this Committee was transferred to the FSA on November 28, 1940. The Family Security Committee was established on February 12, 1941 to study the problem of maintaining the security of American homes in the face of wartime social and economic dislocations. The Committee on Social Protection was established on June 14, 1941 to render advice with respect to the social protection aspects of national defense. ${ }^{31}$

These changes were associated with rising budgets at many of the FSA's bureaus. Although the FSA's budget did not increase continually throughout the war years (and even experienced some decreases during the latter part of the war), the administration's strategy seems to have succeeded in sparing the FSA the more severe funding de-

370 See Part I.D. See also Memorandum from Charles P. Taft to Paul V. McNutt (cited in note 180) (criticizing a Navy admiral's failure to acknowledge to Congress that the National Institute of Health was engaged in experiments to improve high-altitude military flights).

371 Federal Security Agency, Organizational Charts and Budgets, FY 1952 at 1-2 (cited in note 105) (emphasizing the FSA's wartime activities). 
clines that afflicted some major domestic agencies. ${ }^{32}$ Two things are notable about its funding trajectory. First, as Figure 6 indicates, in contrast to other major domestic agencies such as the Federal Works Agency, the FSA fared relatively well in the appropriations game. Even when compared to the massive Agriculture Department, the FSA's decline in funding from its wartime high was more limited, and growth in its appropriations after the war more rapid. Moreover, between 1940 and 1945 the FSA's four major permanent bureaus (those that remained with the agency long-term-the PHS, the Office of Education, the SSB, and the FDA) saw their combined appropriations increase by approximately one-third in constant dollars. Among these bureaus, even sharper increases were apparent at the PHS, whose budget quintupled in constant dollars between 1940 and 1945 .

Second, the declines in funding the FSA experienced between its wartime highest funding levels and the year after the war were less than those of Agriculture and the Federal Works Agency. (Interior experienced a slight rise, but its budget was an order of magnitude lower than those of the other agencies.) As Figure 6 demonstrates, the FSA's four principal bureaus saw steadily rising appropriations with only slight declines in 1943 and 1944, followed by further increases. And some of the FSA's key bureaus-most notably the Public Health Service-experienced pronounced and long-term increases in the rate of growth of appropriations and legal responsibilities. The declines in FSA funding were driven largely by the discontinuation of New Deal-era relief programs such as the Civilian Conservation Corps and the $\mathrm{Na}$ tional Youth Administration. ${ }^{373}$ These developments track the expanding responsibilities of the FSA's four core bureaus and suggest that the agency's leaders and allies successfully marshaled support for its work during and after the war.

372 Budget information is based on the author's analysis of Budget of the United States from 1939 to 1954.

373 See Budget of the United States, Historical Tables, 1945-1955. See also Part I. Analysis of inflation-adjusted changes in appropriations percentages confirm the significance of these appropriations changes over the long term. Note also that total FSA appropriations and those of the preeminent four bureaus eventually converged almost entirely. 
FIGURE 6

THE FSA IN CONTEXT:

CONSTANT 1938 DOLLARS

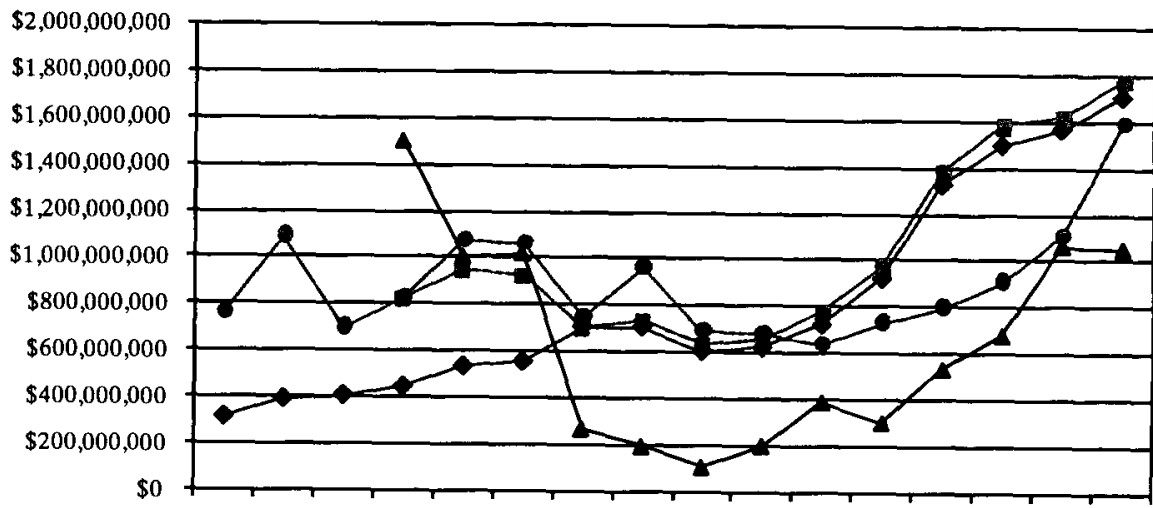

1938193919401940194119421943194419451946194719481949195019511952

Four Major FSA Bureaus Constant Year Total
- FWA Constant Year Total

It may seem as though the national defense-oriented work of the FSA merely reflected a broader change throughout the government. Even if this were the case, it would still be significant that Roosevelt, McNutt, and the rest of the administration sought so emphatically to include the FSA among the coterie of government agencies that could lay claim to importance in a time of war. Nonetheless, the FSA's connection to national security issues appears to have been distinctive not only in the intensity of its public communications but also in the substance of its work. Compared to other major domestic administrative agencies at the time, only the FSA was directly involved in sophisticated weapons research (through the War Research Service). ${ }^{374}$ In the early phase of the war and during the preparation for it, the FSA's administrator, the ambitious Paul McNutt, was the only official appointed coordinator of homeland security matters involving health, welfare, and "related activities," and also chairman of the War Manpower Commission while he continued to serve as FSA administrator." Though all the three agencies Roosevelt created using reorganization authority were justified publicly as essential to strengthening national capacity at a time of international instability, only the FSA's budget

374 See notes $188-192$ and accompanying text.

375 See Blake, Paul V. McNutt at 294-95 (cited in note 105) (stating that McNutt's service at the FSA, the War Manpower Commission, the War Production Board, and the Economic Stabilization Board gave him a "unique vantage point"). 
grew substantially during the war. And only the FSA was specifically structured-from its inception-to include a military liaison. ${ }^{376}$ Finally, the defense-related focus of the FSA lingered well after the war. In sharp contrast to any other domestic administrative agency - whether cabinet or independent-only the FSA's structure included a high-level deputy in charge of defense-related programs. ${ }^{3 m}$

\section{The connection between rebranding and bureaucratic reorganization.}

If it is true that injecting a substantial national defense ingredient into the mix of "security" bureaus could serve the president's goals, why did the White House wait to pursue this strategy until it could order a bureaucratic reorganization? The answers reveal still further ways in which bureaucratic structure can play an essential role in cementing public expectations about government's legal responsibilities.

Although the type of rebranding Roosevelt sought to pull off by melding domestic policy and national defense through an expansive "security" metaphor may not have been impossible to try without reorganization authority, it would have proven far more difficult. Imagine, for instance, how much more trying it would have been for FDR to discuss his expansive version of security during fireside chats if the agencies carrying out that work were scattered bits and pieces across the government (for example, the PHS at Treasury, the FDA at Agriculture, and the Office of Education at Interior). In effect, the reorganization delivered three things that redounded to the benefit of the rebranding. First, the administration gained a high-profile opportunity to announce changes and make a case to the nation about its conception of security. The newspaper coverage of the reorganization announcement was intense, and Roosevelt's "warning to dictators" when he reorganized was widely disseminated. ${ }^{378}$ Second, the administration put in place a structure - consisting of appointees to oversee bureaus with the legal authority to control what they did-to better monitor bureau activities, anticipate threats, and coordinate actions to advance the "expansive" security message. Finally, the administration gained a staff whose job it was in

376 See Letter from Louis Johnson, Assistant Secretary of War, to Rudolph Forster, the White House (Aug 17, 1939), available at Franklin D. Roosevelt Presidential Library, Federal Security Agency, 1939 Folder, Official File 3700.

377 Federal Security Organizational Chart (Jan 1, 1953), available at Harry S. Truman Presidential Library, Papers of Oscar R. Ewing, Federal Security Agency, General Correspondence, Organizational Charts, Box 29 (showing that the FSA had an "Assistant Administrator for Defense Activities" in 1953 when it was on the verge of becoming the Department of Health, Education, and Welfare).

378 See note 251 and accompanying text for a description of media coverage. 
part to promote what the bureaus were doing across the country, build alliances, and manage external relationships in a manner that promoted the desired conception of security.

With the benefit of the framework developed in Part II and the evidence reviewed in Part III, we can revisit some of the lingering questions about the FSA: why Roosevelt forged it in the first place, why it mixed defense and ordinary domestic mandates, and what impact its creation may have wrought. The FSA's creation was a means of increasing presidential control and infusing defense-related missions into the agency as a means of enlarging the coalition supporting administrative and regulatory programs important to the Roosevelt administration. It is of course possible that legislative majorities simply liked the fact that the new agency would help protect the New Deal programs. (This is part of the story developed earlier.)

But a more interesting picture emerges if we examine the situation dynamically. After Congress grudgingly gave the administration limited reorganization authority, the president pushed the envelope, making a mockery of the legal requirement that reorganizations be justified only on the basis of cost savings and administrative efficiency. $\mathrm{He}$ then gained a new layer of political appointees, abolished the Social Security Board's status as an independent agency, and created a new structure through which to fund sensitive presidential projects that he kept shielded from Congress (including political control of grant money and biological weapons research). Perhaps more crucially, he structured the agency to ambiguate national security and domestic administrative functions, thereby creating a means of giving reluctant legislative opponents (and even members of the public) a reason to reexamine what they might be "buying" by supporting the FSA. The result tended to make the agency prosper despite the undeniable New Deal lineage of certain programs.

In contrast, other domestic agencies encountered serious problems during the war years. Agriculture and Interior, both among the most sprawling and important executive departments, assumed some war-related responsibilities as evidenced by the creation of bureaus such as the War Food Authority in Agriculture. ${ }^{379}$ Nonetheless, their budgets stayed flat or fluctuated in comparison to the steady growth in

379 See Division of Public Inquiries, United States Government Manual Winter 1943-1944 at $317-18,324,348-49$ (cited in table 1). 
the FSA's four major bureaus. ${ }^{300}$ The Farm Security Administration, which provided assistance to farmers, also sought to market itself as a war agency protecting the food supply. ${ }^{331}$ Its moves in this direction were complicated, however, by the fractured nature of farming programs split between that agency and the Agriculture Department, the bureau's lack of success forging genuine ties to defense agencies (in contrast to the FSA), and the relatively narrow scope of its overall mission-thereby calling into question its efforts to persuade lawmakers or the public that its legal functions were critical to national security efforts. ${ }^{332}$ In the end, skeptical lawmakers decimated Farm Security's programs and transferred its remaining programs to an even more narrowly focused bureau within the Agriculture Department. ${ }^{339}$ Similarly, the narrowly focused Federal Works Agency, a second major agency born from Roosevelt's fateful reorganization in the spring of 1939, saw its own funding plummet amid waning interest in domestic affairs. Eventually the agency was abolished. ${ }^{344}$ The FSA's broader mix of functions, explicit ties to defense agencies, and greater White House protection spared it such a fate, helping McNutt and other administrators find opportunities for agency growth amid the war.

The creation of the FSA appears to have placed its bureaus on a safer path. Reorganization opened the door to growth in bureaucratic capacity and to reframing the purposes of the agency through incorporation of national security responsibilities, which in turn resulted in larger budgets and congressional acceptance of new legislation that expanded the agency's powers. The agency's eventual cabinet status and the endurance of its major legal mandates are in large measure a testament to the relative success of the Roosevelt administration. As the next Part explains, the success was no coincidence.

\section{IMPLICATIONS AND EXTENSIONS}

The sequence of events triggered by the formation of the FSA has a number of implications in vital areas such as the prospects for agency autonomy and congressional reorganization. Although the available evidence does not establish whether these effects were explicitly intended in the case of the FSA, they nonetheless demonstrate additional goals that politicians may pursue in the course of allocating bureaucratic jurisdictions over legal mandates.

\footnotetext{
380 See Part I.C.

381 See Polenberg, War and Society at 85 (cited in note 114) ("The agency claimed that by helping marginal farmers purchase land and equipment it boosted crop production.").

382 See id at $85-86$.

383 See id at 86.

384 See Part I.C.
} 


\section{A. Changing Capacity for Agency-driven Policy Innovation}

Over time, as their budgets and personnel swelled within an agency focused on health and welfare, some of the FSA's bureaus appear to have acquired greater capacity for autonomous policy innovation. Neither the White House nor Congress lost their grip on the bureaus. Instead, both the rate and the significance of policy innovations emerging from the bureaus quickened compared to what could be observed when the bureaus were in their original bureaucratic environments. These characteristics were buoyed by developments in the bureaus' organizational culture, recruiting practices, and effectiveness in building external coalitions of support.

The FSA bureaus' relative independence is apparent in the agency's policymaking record after the merger and in contrast to what the bureaus had achieved before the merger. Officials at the Office of Education developed plans for new vocational education initiatives. Leveraging the security-related focus at the White House, these officials promoted the new vocational programs among legislators and White House officials. ${ }^{366}$ By 1943, the Office of Education's budget had more than quintupled from its prewar highs, dwarfing the budget of the entire Department of Interior, from which the Office had been transferred just four years earlier. ${ }^{387}$ FSA and SSB employees took the lead in developing major changes to the scope of Social Cecurity coverage during its existence; these changes had not been possible at the outset of the program and appeared to require close collaboration between the FSA staff, the White House, and the SSB staff. ${ }^{38}$ During the existence of the FSA, the NIH grew dramatically, and in a fashion that required promotion of health research and coordination with other agencies that would have been unlikely to materialize had the PHS been a small bureau of the Treasury Department. ${ }^{389}$ After promoting these statutory changes, FSA bureaucrats then insisted to legislative staff that they would require larger appropriations to carry out the changes:

385 See Carpenter, Forging of Bureaucratic Autonomy at 14 (cited in note 235) (proposing that bureaucratic autonomy, and therefore policy entrepreneurship, requires a bureaucracy to develop unique organizational capacities and build political legitimacy through multiple networks and coalitions).

386 See note 183 and accompanying text.

387 See notes $371-373$.

388 Consider Memorandum to the President from the Administrator, Federal Security Agency (Sept 18, 1940), available at Franklin D. Roosevelt Presidential Library, Federal Security Agency, 1940 Folder, Official File 3700 at 16-17 (demonstrating cooperation between the FSA and the White House on crafting social security policy).

389 See Swain, Science at 1236 (cited in note 130) (estimating that between the creation of the Research Grants Office in NIH in 1946 and December 1947, the NIH had awarded almost $\$ 12$ million in grants to external researchers). 
Due to enactment during the closing days of the second session, 79th Congress, of amendments to the Social Security Act, the Public Health Service Act, the Vocational Education Act, and other new legislation, it will be necessary to request additional appropriations to carry out the Federal Security Agency's programs for the fiscal year $1947 .^{390}$

Throughout this time, the FSA administrator served as the senior government official in charge of administering health-related programs. Increasingly, during the Truman administration, the head of the FSA served as the president's primary spokesperson to promote national health insurance and used the resources of the FSA to make the case for it. ${ }^{391}$ No official with such legitimacy and bureaucratic resources would have existed without the FSA. Conservative Southern Democrats and Republicans strongly opposed the elevation of the FSA to cabinet-level status because (according to historians of the period) they did not want to bestow additional status and authority on the FSA administrator. ${ }^{392}$

Even before its rise to cabinet status, the FSA already had a status and role that greatly facilitated the development of health, welfare, and related regulatory policies. By creating the FSA, the White House appears to have facilitated - wittingly or unwittingly - the evolution of the organizational cultures of the component bureaus. In particular, the reorganization signaled to employees of the bureaus that they were part of a larger agency whose core mission was more closely related to their own missions. It allowed these same bureaus to reap the prestige and resources associated with war-related and national security functions. The agency's political appointees emphasized civil service and merit appointments at lower levels ${ }^{333}$ (something increasingly common across some but not all agencies of the federal government) and among grant recipients. ${ }^{394}$ And the new overarching administrative structure provided bureaus with enhanced capacity for outreach, advocacy of agency posi-

\footnotetext{
390 Federal Security Agency, Organizational Charts and Budgets, FY 1946 (1946), available at National Archives, Organizational Charts, Federal Security Agency, Entry 9, Box 1.

391 See Quadagno, One Nation, Uninsured at 35 (cited in note 145).

392 See Miles, The Department of Health, Education, and Welfare at 23-24 (cited in note 13) (suggesting that "considerable separatist inclination on the part of some components of the FSA" combined with opposition to Truman's national health insurance plan doomed both of Truman's attempts to promote the FSA). See also Truman Undecided, May Again Ask Agency Bill, LA Times 18 (Aug 19, 1949) (describing how a "coalition of Republicans and Southern Democratic Senators" gave Truman "one of his severest setbacks of the session" by voting against his plan to create a new welfare department).

393 See Derthick, Policymaking for Social Security at 28 (cited in note 225) (noting that the chairman of the SSB wanted to hire the best people in the country).

394 See Swain, Science at 1236 (cited in note 130) (stating the NHH's grant program objective "to encourage the development and to further the training of competent young researchers").
} 
tions with respect to other entities of government, and access to the White House. Together, these changes may have spurred some of the qualities that allowed the agency to gain a measure of autonomy in pursuing significant policy changes on Capitol Hill. ${ }^{355}$

As these changes took hold within and around the federal bureaucracy, the FSA's own administrators sought to trumpet the organization's new esprit to employees and the public. Discussing the management of his agency with congressional appropriators in early 1950, Administrator Oscar Ewing put it thus:

The movement toward a cohesive Agency has not resulted only from [ ] administrative shifts; it has resulted in considerable measure from an increasing desire by the heads of all the units to work together to strengthen the Agency. Without such cooperation what progress we have made would have been extremely difficult, if not impossible.

Bureaucratic autonomy has proven essential to many features of modern life mediated through legal and policy programs promoted by autonomous bureaucratic actors. Structural changes can and do presage such autonomy. To the extent that other political actors recognize this and have a stake in promoting such autonomy (or avoiding it), they will attempt to shape bureaucratic structures with an eye on the autonomy-related consequences. Thus, structural changes may prove fundamental to understanding the evolution of legal mandates.

\section{B. Expanded Pressure for Legislative Reorganization}

The creation of the FSA provoked intense debate in Congress in part because of the potential that it would create pressure to change existing congressional jurisdiction among committees. ${ }^{37}$ Eventually, the realignments in executive branch functions did lead a reluctant Congress to sharply reform existing committee jurisdictions. ${ }^{398}$ In the short term, the reorganization plan that allowed the FSA to be created also led to the establishment of a reorganization committee in Congress. Although neither this committee nor the reorganization plan itself had

395 See Carpenter, The Forging of Bureaucratic Autonomy at 14-33 (cited in note 235) (discussing the factors that make it possible for agencies to enhance their autonomy).

396 See Hearings on Federal Security Agency Appropriations for 1951 before the Subcommittee of the House Committee on Appropriations, 81st Cong, 2d Sess 663 (1950) (testimony of Oscar E. Ewing, Federal Security Administrator).

397 See Morrow, Congressional Committees at 241-45 (cited in note 132) (explaining that government reform proposals may be opposed by congressional committee members "who want to preserve the status quo for personal [and] political reasons").

398 See id at 9 (stating that the Legislative Reorganization Act of 1946 reorganized committees in Congress to match organizational changes in the executive branch). 
the power to directly change the allocation of committee jurisdiction, both allowed for changes in the executive branch that had the potential to generate more conflicts among committees (for example, as where a committee given primary jurisdiction over a newly reorganized agency could be in conflict with a committee retaining jurisdiction over a lower-level bureau). ${ }^{399}$ In the longer term, the FSA and similar reorganizations created growing pressure for the legislature to reshape committee jurisdictions to account for the changes in the executive branch. ${ }^{400}$ Eventually, during the $1940 \mathrm{~s}$, these pressures led to the most dramatic changes in congressional jurisdiction in modern history. ${ }^{401}$ Congress also made decisive procedural changes that dramatically enhanced lawmakers' capacity to monitor the swelling bureaucracy that the executive had come to control more closely.

These changes underscore how one important implication of bureaucratic structure is its effect on the probability of subsequent congressional reorganization. Even if such reorganization is resisted in the short term - as it largely has been in recent years after the crea-

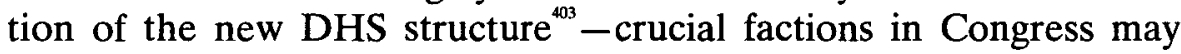
eventually find that the mismatch between executive reorganizations and the internal allocation of legislative power becomes all but impossible to ignore. Legislative entrepreneurs can use the disconnect between legislative and executive organization to agitate publicly for a different jurisdictional arrangement (as did Senator Joe Lieberman years later in the homeland security context ${ }^{24}$ ). The mismatch between legislative and executive organization can also make it harder for legislators to oversee bureaucratic activity when responsibility falls between the cracks of existing committee coverage. Even when this is not the case, the lack of fit between congressional and executive structure generates jurisdictional disputes that require resolution by com-

399 See id at $20-22$.

400 See id at 52 (stating that the Legislative Reorganization Act of 1946 provided each committee with an independent research staff to "counter the evolving specialization of the executive branch").

401 See Morrow, Congressional Committees at 20 (cited in note 132) (noting how the 1946 reorganization of Congress reduced the number of standing committees in the House and Senate by more than 50 percent).

402 See Mathew D. McCubbins, Roger G. Noll, and Barry R. Weingast ("McNollgast"), Structure and Process, Politics and Policy: Administrative Arrangements and the Political Control of Agencies, 75 Va L Rev 431, 441-42 (1989) (discussing how legislators can use administrative procedures to prevent agencies from carrying out a "fait accompli" that the legislators then find difficult to reverse).

403 See Cohen, Cuéllar, and Weingast, 59 Stan L Rev at 699 (cited in note 26) (noting that the DHS reorganization bill did not address congressional committees and that as late as mid-2004 congressional oversight had yet to change).

404 See id at 690,695 (describing how Senator Lieberman introduced and aggressively pushed for the reorganization legislation that eventually created DHS). 
mittee chairs and the congressional leadership. ${ }^{405}$ For all these reasons, when executive agencies are reorganized, legislators receive a lottery ticket that could yield gains or losses in the power of committees in which the members have a vested interest. The ex ante fight over bureaucratic structure becomes even more convoluted because the returns from that lottery are not distributed equally for legislators. ${ }^{46}$

While the executive-legislative nexus in reorganization helps explain why fights over structure can become so intense, it also reiterates questions about the prescriptive merits of such reorganizations. Leave aside the substantive problem of agreeing on the precise meaning of efficiency or effectiveness in the context of a government program with contested functions. Even assuming that it could be shown that centralization of functions was wiser relative to some defensible set of policy goals, there is a separate question regarding legislative power. Effective centralization depends to some extent on legislators allowing that centralization to be meaningful. But when legislatures reorganize committee jurisdiction, it may not even be in a way that furthers the goals of a particular agency. ${ }^{407}$ In the case of the FSA, Congress eventually did reorganize, and it tightly vested primary responsibility for the agencyand its future cabinet-level offspring-in a small number of committees. The larger lesson from the FSA story here is that bureaucratic reorganizations have the potential not only to affect the balance of power between the White House and Congress but also to reshape the allocation of power within Congress itself.

\section{An Organizational Gloss on Separation of Powers}

A common theme runs through battles over executive reorganization in the 1930s, cabinet-level status for the FSA under Oscar Ewing in the 1940s, and the shape of DHS in the early twenty-first century. In each of these conflicts, the players came to realize that choices about agency architecture inevitably affected the relationship between bureaus carrying out legal responsibilities and external pressures. As such, questions about agency architecture - whether legal authority is wielded by a single administrator or a fragmented board, how easy or

\footnotetext{
405 See id at 693-94 (recounting how Speaker of the House Dennis Hastert had to empanel a new committee to move the reorganization legislation forward).

406 See id at 693 (pointing out that the initial congressional supporters of the DHS reorganization were those who "almost certainly stood to gain prestige, power, and influence").

407 See Cohen, Cuéllar, and Weingast, 59 Stan L Rev at 710 (cited in note 26) (arguing that there is always a large amount of uncertainty about the prescriptive benefits of a reorganization); Wilson, Bureaucracy at 264-65 (cited in note 23) (discussing the difficulty in assessing the range of motivations for specific reorganization plans given that "presidents have taken to reorganizations the way overweight people take to fad diets").
} 
difficult it is to fire a senior agency official, and what essential missions an agency prioritizes - are inevitably matters affecting the president's power to control the legal machinery of the regulatory state. The Supreme Court recognized as much at least as early as Myers. ${ }^{408}$ The Court's analysis turned on the intimate connection between the ease with which a president could control an agency and the overall balance of powers among branches. ${ }^{49}$ In effect, the Court laid out why questions of agency architecture were likely to remain preeminent separation of powers concerns across the decades. By understanding episodes of structural choice such as the evolution of the FSA, we can better understand at least three realities concerning legal debates over executive power.

First, "functional" separation of powers analysis almost inevitably involves regulating different political actors' power over agency structure. As at least some courts and policymakers have realized, many problems in separation of powers doctrine involve questions about the amount of actual control a president can exercise over the bureaucra$\mathrm{cy}^{4{ }^{410}}$ By the time of Sierra Club v Costle, ${ }^{411}$ for example, courts routinely approached separation of powers questions by trying to calibrate precisely the extent of presidential power over internal agency matters. $^{42}$ In Costle, the DC Circuit simultaneously acknowledged the value of judicial oversight of the president-agency relationship while recognizing that such oversight could also adversely impact the bureaucracy. ${ }^{413}$ Indeed, right after Humphrey's Executor the stage was already

408 See 272 US at 176.

409 See id at 117 (reasoning that the president's obligation to execute the laws passed by Congress necessarily requires that the president be able to hire and fire administrative officers in the executive branch).

410 The extent to which internal constraints on presidential control of the executive branch could substitute for power across branches is a central point in Neal Katyal's recent discussion of presidential power. See generally Neal K. Katyal, Internal Separation of Powers: Checking Today's Most Dangerous Branch from Within, 115 Yale L J 2313 (2006). Katyal tends to think of bureaucratic fragmentation as a distinct parameter that can be essentially disentangled from traditional separation of powers debates. In contrast, the story of the FSA highlights the connection between the macrolevel separation of powers questions and bureaucratic fragmentation, particularly when viewed against the backdrop of the long history of constitutional disputes over the management of executive branch architecture. To an underappreciated degree, those disputes also reflect the curious relationship between more extensive presidential control in the short term (which can be used to build agency resources, nurture agency reputations, and develop a desirable mission), and greater independence in the long run.

411657 F2d 298 (DC Cir 1981).

412 See id at 312 (holding that the Environmental Protection Agency did not exceed its statutory authority under the Clean Air Act when it promulgated new coal-fired power plant emissions standards).

413 Compare id at $406-07$ (recognizing that in some instances it may be impermissible for administrative rulemakers not to "docket" the "conversations between the president or his staff and other Executive Branch officers or rulemakers" during the post-comment period of rulemaking), 
set for the rise of a more functionalist paradigm in separation of powers law. With its decision in Humphrey's Executor, the Court simultaneously denied the White House a major instrument of control and ratified legislative experimentation with structures insulated from presidential control (for example, independent commissions). ${ }^{41}$

The White House responded to such constraints through a determined effort to gain the executive reorganization authority that eventually led to the creation of the FSA. Despite the difficulties created by court decisions such as Humphrey's Executor, the swelling size of the federal government relative to the size of the White House staff, and basic problems obtaining information across government, greater presidential success in achieving structural goals is likely to be associated with greater power to affect what federal bureaus actually do. Indeed, presidents' relative successes in achieving structural goals such as the creation of the FSA or DHS further blur a distinction - quite central to some otherwise cogent accounts of separation of powers-between presidential "oversight" and "directive authority." thority implies that the president holds a special power to legally compel a decision from a subordinate, whereas oversight implies a power to force consultation and the production of information-something short of a specific decision. But in the absence of such explicit "directive" authority, presidential power to reorganize who holds directive authority within organizations (as Roosevelt did when he placed the SSB inside the FSA), to appoint loyal political supervisors to bureaus, and to control the flow of information to and from bureaus can limit the significance of formal distinctions between "oversight" and "directive authority."

Even if some subordinate executive branch officials let their responses to presidential requests turn on the distinction between oversight and directive authority, it is far from obvious that all or even most employees would be so passionately invested in the distinction. Structural changes can therefore help a president limit the significance of formal distinctions between oversight and directive authority. Accordingly, because separation of powers doctrine only makes sense if it encompasses some limits on presidential power and structural arrangements are a key determinant of such power, courts should (other things being equal) prudently but closely scrutinize structural changes pursued by the White House. In fact, courts genuinely concerned with

with id at 406 ("Our form of government simply could not function effectively or rationally if key executive policymakers were isolated from each other and from the Chief Executive.").

414 See id at 625.

415 See, for example, Peter L. Strauss, Overseer or "The Decider"? The President in Administrative Law, 75 Geo Wash L Rev 696, 759 (2007) (arguing that the default rule in separation of powers grants the president oversight authority to ensure laws are executed but not decisional authority to interpret statutes and promulgate rules). 
policing the extent of executive power will be left with little choice but to scrutinize the extent of structural power the president in fact has been able to accrue, rather than merely relying on a formal examination of whether the president has made claims of authority that improperly violate the distinction between oversight and directive authority.

Second, the president's relationship with the FSA after reorganization shows how key practices sometimes treated as legal innovationssuch as close White House and agency collaboration in the development of regulatory rules, presidential credit-claiming for agency initiatives, and efforts to build alliances with career staff-have a longer history than commonly supposed..$^{47}$ Roosevelt doggedly sought reorganization authority at a time when the federal government was growing massively. The political stakes in controlling new regulatory bureaucracies were high, and the ratio of White House employees to total federal employees was declining. With Congress and the Supreme Court blocking the methods Roosevelt had earlier sought to use (control over appointments and the expansion of the White House staff), ${ }^{418}$ the administration turned to structure as a powerful substitute. Having fashioned a new arrangement at the FSA, the White House used a mix of techniques including approval and announcements of grants (which Roosevelt instructed FSA Administrator McNutt to clear with the White House), setting regulatory priorities (which White House staff monitored with bureau personnel at the SSB and the FDA), and controlling the flow of bureaucratic and financial resources (which the White House staff did through its new Bureau of the Budget). ${ }^{49}$

Third, the now longstanding presidential move to control structure plainly apparent in the late 1930s-and running through the entire history of the FSA and its transformation into the Department of Health and Human Services-is consistent with a nuanced and complicated, if realistic, view of separation of powers as a set of standards ra-

416 In some respects, the doctrinal progression in this domain reflects at least some attention to the position of sustained but prudent scrutiny of presidential control of structure. Such attention is evidenced in the adoption of an increasingly functionalist separation of powers jurisprudence that acknowledges dynamic changes, a somewhat more flexible standing jurisprudence including, in Massachusetts v EPA, 549 US 497 (2007), the recognition of "procedural" injuries that might encompass the executive branch's failure to honor lawmakers' decisions to vest authority in particular inferior officers rather than the president, and a concern with placing limits on reservoirs of presidential power to affect the structure of government by pressing the limits of agency authority.

417 See, for example, Kagan, 114 Harv L Rev at 2301-03 (cited in note 61) (suggesting that Clinton's practice of publicly announcing regulatory actions often pushed White House staff to coordinate with the agency on the final rule and also allowed Clinton to claim credit for the agency's successes).

418 See Part I.

419 See Part III. 
ther than rules. In that view, the branches are necessarily entangled because they are codependent. Sensibly - perhaps inevitably - the Supreme Court has recognized structural issues as being so central to the overall architecture of the federal state that it required power sharing. ${ }^{420}$ Facing these doctrinal trends, the president pushed back in two ways amply illustrated by the story of the FSA: by grabbing as much power over structure as possible (something that required compromise with the legislature) and by insisting that "security" required structural reform (for example, to strengthen the performance of bureaus with missions relating to security and to enhance the nation's geostrategic security against external threats). The pattern continues to the present, with the Bush administration's insistence on security as the fundamental rationale for reforging a massive chunk of the federal government into DHS - with power over domains ranging from reimportation to refugees - while simultaneously proposing a sharp expansion of presidential power over the agency's myriad bureaus.

Because presidents enjoy residual power over the difficult-toobserve details of quotidian executive branch management, austere restrictions of presidential power over structure (going beyond restrictions on powers arguably peripheral to core executive branch functions such as those at issue in Humphrey's Executor and those in traditional cabinet-level departments) can be hard to achieve-and if achieved, they might prove damaging to the president's ability to function as expected. On the other hand, blocking Congress from participation in this key domain is a plain recipe for staggering imbalance. Arguments could be made that too much branch blurring can complicate accountability (for example, the public assignment of responsibility) in a world of information-poor, cognitively constrained voters. ${ }^{42}$ But absent convincing arguments in this regard, power over structure should be properly subject to sharing by branches that have learned, over time, to treat structure as a powerful tool to shape implementation of current law, future agency trajectories, and public expectations of what government

420 This is what cases such as Myers, Humphrey's Executor, and Weiner v United States, 357 US 349 (1958) (holding that the president could not remove a member of the War Claims Commission "merely because he wanted his own appointee["), are ultimately about. If they are not about the sharing of power, they make no sense at all.

421 See Cohen, Cuéllar, and Weingast, 59 Stan L Rev at 722-25 (cited in note 26).

422 See E.E. Schattschneider, Party Government 14 (Farrar and Rinehart 1942) (arguing that explicit party control of government was a critical component of citizens' opportunity to meaningfully engage in democratic politics). But see generally Arthur Lupia and Mathew D. McCubbins, The Democratic Dilemma: Can Citizens Learn What They Need to Know? (Cambridge 1998) (marshaling experimental evidence and theoretical arguments to bolster the case that a variety of institutional mechanisms simplify the public's task in making meaningful political decisions). 
does. In effect, blocking the sharing of power over structure inevitably disrupts an arrangement of separated powers.

The continuing competition over control of structure in the wake of the Court's decision to split power over bureaucratic structure sheds a different light on the presidentially inclined arguments of the Brownlow Committee. In particular, the efficiency rationales offered by the Brownlow Committee, promoted by Roosevelt, and then offered again by the Hoover Commission during the Truman administration, were consistently undertheorized, even as they probably reflected the reality of presidential competition for control in a system of separated powers. $^{423}$ The efficiency rationales did not take into account the elements of separation of powers jurisprudence designed to complicate rather than facilitate policymaking. They did not consider the transition costs. They did not take into account the potential benefits of decentralization. $^{424}$ And in part perhaps because of such limitations in the technocratic arguments for organizational restructuring, key players understood at least some of the highly political stakes in reorganization - this is why both Truman and Roosevelt ran into so much political trouble when they pursued it. These observations raise a number of questions, of course, but they should lead us to be skeptical of claims by proponents of the unitary executive thesis that reorganization efforts support their claims of broad historical acknowledgement of the need for substantial executive power relative to Congress. ${ }^{425}$

\section{The Complexities of Security}

The Roosevelt administration found in the concept of security a vehicle for engineering an expanded federal state. It did not, however, take the concept of security as a given. Given their apparent success in reframing the work of what was supposed to be a "Department of Public Welfare and Health," the administration's tactics illustrate two important points about the modern state. First, by the early twentieth century, citizens had come to expect the state to provide for their security. During the 1930s, many (though not all) uses of the term were commonly associated with social welfare programs designed to promote economic security. Many observers at the time might have un-

423 See Part III.A.1.

424 Here again, parallels to the creation of DHS abound. See Cohen, Cuéllar, and Weingast, 59 Stan L Rev at 718 (cited in note 26) (discussing the relative absence of congressional or executive branch discussion reviewing the costs of greater centralization).

425 See, for example, Christopher S. Yoo, Steven G. Calabresi, and Laurence D. Nee, The Unitary Executive during the Third Half-century, 80 Notre Dame L Rev 1, 107 (2004) (arguing that Roosevelt's reorganization plan supports the idea of a the unitary executive as a "constitutional custom"). 
derstood a "security state" to imply not a government focused on deterring geostrategic military and terrorist threats, but one endeavoring to cushion its citizens against economic and natural calamities. ${ }^{426}$

Yet second, then as now, the concept of security proves to be inherently malleable, raising questions about the viability of approaches to legal interpretation that assume a tidy distinction between geostrategic national security and other types of safety and security. Although the term "security" was not unknown in military contexts at the time, the Roosevelt administration's strategy seemed premised on the idea that the concept could nonetheless comfortably encompass government activities that would benefit civilians and the military alike. As the Cold War picked up speed, the FSA gave birth to staples of modern government with defense and civilian applications such as an expanded National Institutes of Health and Centers for Disease Control. ${ }^{27}$ The transformation of the term continued, to a point where the more salient association is with manmade violence and government officials actually question the extent to which FEMA's disaster relief responsibilities are appropriately understood to encompass "security.", "28

In retrospect, the determination on the part of FSA and administration officials to convey their views to the public showcases the overlapping terms of the rhetorically powerful yet fundamentally contestable concept of "security," which politicians can deploy strategically to advance a host of domestic and international goals. For example, the agency's trajectory suggests that the term can implicate health and welfare services providing personal social and economic security. Perhaps the term also evokes the notion that the provision of health and welfare services can help forestall domestic unrest and more radical political change (the critique of revisionist New Deal historians) ${ }^{429}$ The work of the FSA can also be understood to have a sort of externality effect on national security, as traditionally understood: war adjustment services, education for war production, biological weapons research, and facilitating the movement of interned Japanese-Americans. Finally, the most ambitious conception of security is one that the Roosevelt administration seemed occasionally bent on promoting, though history reveals that it never entirely succeeded: security as an all-encompassing

426 See Part III.B. See also generally David M. Kennedy, Freedom from Fear: The American People in Depression and War, 1929-1945 (Oxford 1999).

427 See notes $150,226,347$, and 353 and accompanying text

428 See Cohen, Cuéllar, and Weingast, 59 Stan L Rev at 723 (cited in note 26) (noting that legislators questioned whether FEMA's domestic policy mandate made it a good candidate for reorganization into DHS).

429 See, for example, Leuchtenburg, Franklin D. Roosevelt and the New Deal at 104-05 (cited in note 25) (describing the Townsend plan for old-age insurance that was far more redistributionist than the eventual social security program created by Roosevelt). 
freedom from fear and want-whether its source is domestic insurrection, external aggression, disease, or economic deprivation. One of the many eloquent public statements in support of this particularly expansive version of the "security" concept is found in the second annual report of the FSA:

The security of America has always rested upon a foundation of cooperative effort. From our earliest days when struggling colonies on the seaboard faced the everpresent threats of famine, cold, and hostile tribes; from the days of the Revolution when all the colonies banded together to assure their economic survival; down through the years to more recent times when the Nation's only enemies were internal ones-mass joblessness, poverty, and suffering-Americans have come together, jointly to consider and solve their mutual problems.

The active role assumed by the Federal Government in the last decade in helping the individual to find security is as natural and inevitable in the American scheme of things as early barnraisings and corn-huskings. In early years, cooperative effort to assure individual security was possible on a voluntary scale, but gradually the changes in economy and the amazing growth of this Nation geographically and numerically have made government action necessary - first, by local units and, as time went on, by larger and ever-larger governmental units until the Federal Government entered the picture. But today, as in colonial days, collective action provides only the foundation and the opportunity for each man to build his own security.

If the story of the FSA shows that such a conception did not take permanent root in American law and politics (given today's more rigid separation between national security and economic security, for example), it does show that politicians saw it as a coherent concept worth advancing with the public. And even today, this "thick" version of security finds resonance in the concerns of international organizations, advocates, and governance reformers with "human security" as an alternative to narrowly tailored conceptions of physical security."

The reality of external conflict was an important change in the FSA's context. Impending war made it easier for the administration to blur the distinction between physical security and the more expansive

430 Federal Security Agency, Second Annual Report at 1 (cited in note 126).

431 See, for example, S. Neil MacFarlane and Yuen Foong Kong, Human Security and the UN: A Critical History 129-33 (Indiana 2006) (summarizing some policymakers' and theorists' attempts to expand "security" from the Cold War's focus on the military to economic, societal, and environmental factors). 
variation on the theme. War made it far simpler for McNutt and his subordinates, in countless conferences and public speeches, to demonstrate how public health infrastructures, placement services for jobseekers, and education grants could serve the war effort. This aspect of the account should not be surprising. It fits with the notion, associated most strongly with Charles Tilly, that "war makes the state.", of war helped make the FSA, which spawned the modern federal bureaucracies that powerfully affect major aspects of our lives today.

But the implications of the FSA for the analysis of "security" go beyond the notion that war can spur state-building. As it happens, the FSA's relentless campaign to yoke its mission to national security proved to be more than a public relations effort. The campaign was, in some sense, providing an apt description of certain realities of the FSA's day-to-day activity. Some examples: the work of the Public Health Service in limiting disease and providing services to civilians, the military, and those civilians who would eventually join the armed forces; the role of physical education programs in preparing youths to join the armed forces; the role of the FDA in assuring a safe food supply and pharmaceutical products to both the public and the military; and the agency's role in training individuals for service in war-related industries and then placing them there. ${ }^{433}$

Although Roosevelt's expansive security ideas may have had a darker side, there is nothing inherently strained about the Roosevelt administration's elastic rendering of the "security" mantle. It seems at least as plausible that the FSA's amalgam of administrative and regulatory activity would contribute to a compelling definition of safety and security as it is to expect that the projection of naval force abroad would contribute to security. An internal White House memorandum summarized a letter from M.S. Robertson, an official of the National Education Association (and admittedly someone with a vested interest):

Wrote to the president re reports to the effect that secret agencies are working among the negro population in the South, urging the negroes to show their sympathies to the enemies of the US because of discriminations which exist in the South against

\footnotetext{
432 See Tilly, European Revolutions: 1492-1992 at 32 (cited in note 171) ("The organization of war made a fundamental difference to the character of states.").

433 See id at 33-35 (describing how war leads states to circumscribe and inspect the movement of capital, labor, and goods; to exert more extensive regulatory, surveillance, and educational controls over populations and commerce; and to expand the obligations that citizens owed to the state and vice versa).
} 
negroes .... Asks that the President place his influence behind legislative efforts to solve these problems. ${ }^{43}$

Choosing to leave aside questions about the factual plausibility of Robertson's concern about subversives among African-Americans, the president's response suggested at least an appreciation of the ultimate stakes involved in the performance of administrative and regulatory programs he had so aggressively sought to better control. The internal White House memorandum summarizing the correspondence notes:

The President replied June 4, saying he is in complete sympathy with efforts in the south or elsewhere in the country to improve educational opportunities for all children and to equalize educational facilities among all groups in our population. He said it is his belief that we have made and are making great social progress, and that he recognizes the importance of adult education in solving the problems Mr. Robertson mentions, and hopes everything possible may be done, in keeping with our defense efforts, to assure the full cooperation of everyone in the present crisis. ${ }^{435}$

Perhaps the president's response was simply a political sop. History has shown, however, that politicians-whether democrats or dictatorsdisregard the essential insight of the past at their peril. ${ }^{436}$ If war makes the state, it is also true that bureaucratic capacity allowing the state to regulate, to protect critical infrastructures, and to quell the raw edge of political dissent through redistribution programs all play a central role in nearly any plausible account of national defense.

Indeed, the current concerns with homeland security have increasingly come to encompass infrastructures and public health mechanisms easily framed by some lawmakers or scholarly observers as critical to national life. Although the creation of a Department of Homeland Secu-

434 Internal White House Memorandum, Summarizing Correspondence with M.S. Robertson, President, Department of Adult Education, National Education Association (Baton Rouge, La) (correspondence May 14, 1941, circa June 3, 1941), available at Franklin D. Roosevelt Presidential Library, Federal Security Agency, 1941 Folder, Official File 3700 (noting the letter from Robertson requesting Roosevelt's help in furthering civil rights efforts).

435 Id.

436 See Adam Przeworski, Democracy and the Market: Political and Economic Reforms in Eastern Europe and Latin America 33 (Cambridge 1991) (arguing that democratic institutions cannot sustain themselves unless they give "all relevant political forces" either a chance to win the "competition of interests and values" or the impression that "losing will not be all that bad"); Samuel L. Popkin, The Rational Peasant: The Political Economy of Rural Society in Vietnam 258-59 (California 1979) (arguing that the growth of revolutionary sentiment in Vietnamese villages can be explained by analyzing how the villagers gambled on an "improvement in the status quo"); Barrington Moore, Jr, Social Origins of Dictatorship and Democracy: Lord and Peasant in the Making of the Modern World 459 (Beacon 1966) (suggesting that integrating the rural population into a nation's overall economic relations will generally tamp down on rural social unrest). 
rity appears to have fomented cuts in domestic regulatory mandates, such a development does not necessarily signal the demise of "security" as an organizing principle for promoting domestic regulatory and administrative activity. It is worth noting that both the rhetoric and the underlying substantive concerns advanced by some observers and policy entrepreneurs in the homeland security arena bear more than a passing resemblance to the FSA's mandates more than six decades ago. Their basic message is as simple as it is reminiscent of McNutt's and Roosevelt's speeches: a narrow focus on violent, manmade, geostrategic threats is a poor recipe for security, and even when the focus remains on those more conventional threats to national defense, success depends heavily on the nation's human and regulatory infrastructure. ${ }^{437}$ In the national experience with the FSA, policy entrepreneurs may find hints about the viability of political coalitions supporting the development of bureaucratic capacity to achieve a blend of regulatory, redistributive, and more conventionally understood geostrategic national security goals.

Yet amid such underlying complexity associated with defining the nation-state's core responsibility to its citizens, only the barest hint seems to register in the emerging domain of legal practice and scholarship now defined as "national security law." Instead, that domain is primarily defined by attention to surveillance and investigation, ${ }^{4.8}$ coercive authority to detain or use force, ${ }^{439}$ and presidential power over emergencies or foreign affairs. ${ }^{40}$ These topics are unquestionably important, but they leave aside two areas that national security scholars and practitioners take for granted at their peril. First, what individuals or interests actually secure control of bureaucracies with complex, overlapping international security and domestic regulatory functions? The new institutional architecture defining FSA not only advanced Roosevelt's own brand of security as a rationale for legal change, it also left the White House in a stronger position to control a major spigot

437 See Cohen, Cuéllar, and Weingast, 59 Stan L Rev at 735-38 (cited in note 26). See also Stephen Flynn, America the Vulnerable: How Our Government Is Failing to Protect Us from Terrorism 14-15 (HarperCollins 2004) (advocating a conception of security that encompasses critical infrastructure protection, public health, and natural disaster mitigation and relief).

438 See, for example, Heidi Kitrosser, "Macro-transparency" As Structural Directive: A Look at the NSA Surveillance Controversy, 91 Minn L Rev 1163, 1164 (2007) (questioning the Bush administration's push for secrecy in national security investigations).

439 See, for example, Robert Chesney and Jack Goldsmith, Terrorism and the Convergence of Criminal and Military Detention Models, 60 Stan L Rev 1079, 1121-32 (2008) (suggesting improvements in the current system of nontrial preventive detention).

440 See, for example, David Golove, United States: The Bush Administration's "War on Terrorism" in the Supreme Court, 3 Intl J Const L 128, 128 (2005) (arguing that Supreme Court decisions rejecting the Bush administration's detention of "enemy combatants" represent a "judicial effort to counter the radical vision of constitutional law" propounded by the administration). 
of federal grants and align the bureaus' priorities with those of the administration. ${ }^{41}$ Similarly, the impact of creating DHS decades later advanced the Bush administration's own version of a (counterterrorism-focused) security agenda ${ }^{42}$ but also recast the statutory authority governing the immense department's bureaus and left the secretary of DHS with greater power over them. ${ }^{443}$ The creation of the Energy Department ${ }^{\text {t4 }}$ and passage of the Goldwater-Nichols Department of Defense Reorganization Act of $1996^{45}$ also showcase how statutory changes putatively designed to achieve sensible prescriptive goals in national security inevitably also operate to reallocate control over central functions of the nation-state.

Second, how are the limits of security even defined? With the FSA and DHS, the question holds relevance in the intersecting domain where the agencies simultaneously interpret their underlying statutory authorization while explaining their mission to a larger public capable of ultimately affecting the agencies' political context. The question holds even more direct significance in a host of adjudicatory contexts, ranging from presidential regulatory and surveillance powers ${ }^{46}$ to immigration." Without greater engagement with these domains, the more traditional elements of national security law will fail to provide a full picture of how law, security, and the nation-state continually define each other in a world of fluid-both bureaucratic and national-boundaries and alliances.

\section{CONCLUSION}

The wartime experiences of this Agency, which form so large a part of its background as a unified Agency to date, demonstrated the practicability and clarified the validity of wholesome cooper-

441 See Part III.A.

442 See Cohen, Cuéllar, and Weingast, 59 Stan L Rev at 681 n 24 (cited in note 26).

443 See id at 696-97 n 95 (discussing the Homeland Security Act's provisions vesting in the Secretary the power to decide precisely how agencies should balance legacy mandates and counterterrorism).

444 See Terrence R. Fehner and Jack M. Holl, Department of Energy 1977-1994: A Summary History 21-23 (US Department of Energy 1994) (describing the nuclear security and national defense organizational functions transferred to the newly created Department of Energy during the Carter administration); Edward Cowan, Who Needs the Energy Agency, NY Times 81 (May 30, 1976) (discussing the changes in bureau control that the creation of a new department would entail).

445 See also Zegart, Flawed by Design at 131-63 (cited in note 214) (discussing the political conflicts over bureaucratic control associated with crafting the Goldwater-Nichols legislation, and the changes in authority associated with the bill's passage).

446 See, for example, Youngstown Sheet \& Tube Co v Sawyer, 343 US 579, 664-65 (1952).

447 See Immigration and Nationality Act of 1952, 66 Stat 163, codified at 8 USC $\$ 1101$ et seq. Before 1990, the Act defined subversives subject to removal to include, among other categories aliens whom the attomey general believed had entered the United States to engage in activities endangering the national security of the nation. See S Rep No 1515, 81st Cong, 2d Sess 787-801 (1950). 
ation and intelligent integration of the several security programs. The challenge facing the Federal Security Agency as it enters fiscal 1947, its first year in a peacetime world, is: Can the unstinting efforts so freely joined to help assure victory in a world at war be mobilized to help assure to the people of the United States a fuller life in a world at peace? ${ }^{448}$

On June 7, 2002, President George W. Bush announced a major initiative reshaping the architecture of the federal government to promote greater security for the American people. ${ }^{49}$ DHS was the result. Unmistakable parallels link that initiative to Roosevelt's creation of the FSA sixty-three years earlier. Like Roosevelt, President Bush faced a national electorate growing increasingly concerned about international threats. The early twenty-first century White House, like its predecessor in the 1930s, harbored an ambitious domestic policy agenda that would be affected by the reorganization. Both administrations faced hostility over their accumulation of presidential power, ${ }^{450}$ and nonetheless sought to use reorganization to enhance their control over how laws are implemented in a sprawling regulatory state. Both ultimately succeeded in achieving their respective reorganizations.

Where each administration differed sharply is in how it defined the concept of security that the newly strengthened legal architecture of government was supposed to serve. In Bush's case, the reference to security implicated primarily the management of risks from terrorism or geostrategic threats, a narrowly focused mandate sharply conflicting with transferred bureaus' broader missions and helping to create conditions making DHS perennially troubled. ${ }^{451}$ In Roosevelt's case, the term security was meant to evoke a flexible conception of risk reduction that spread-like the FSA's jurisdiction eventually did-across the now-segregated domains of public health regulation, social welfare policy, and national defense. Against that backdrop, early FSA officials managed to create an environment supporting their bureaus' legal functions and adding to their resources rather than one calling for drastic reforms in agency priorities amid sharp resource constraints. ${ }^{452}$ Even

448 Federal Security Agency, Annual Report for the Fiscal Year 1946 at xvi (cited in note 335).

449 See Cohen, Cuéllar, and Weingast, 59 Stan L Rev at 692-93 (cited in note 26).

450 Compare Mariano-Florentino Cuéllar, The Untold Story of al Qaeda's Administrative Law Dilemmas, 91 Minn L Rev 1302, 1304-05 (2007) (describing controversies regarding legal decisionmaking in the Bush administration), with Polenberg, Reorganizing Roosevelt's Government at 55 (cited in note 22) (discussing criticisms of Roosevelt's alleged overreaching in bolstering executive power).

451 See Cohen, Cuéllar, and Weingast, 59 Stan L Rev at 696-97 (cited in note 26).

452 Compare id at 728 (discussing the combined impact of revenue neutrality and new missions), with Part III (discussing how the FSA's broader security mission and layer of political officials contributed to capacity-building). 
after Roosevelt's death, FSA Administrator Oscar Ewing continued articulating the same notion of security as "a sure knowledge that we shall not want for the basic necessities of life, no matter what Fate may have in store,",53 one that eerily parallels the views of some observers who criticize DHS for not being more steadily focused on the full range of risks facing Americans today. ${ }^{44}$ What exactly it means to secure the nation remains a foundational question defining the law's evolution.

But despite some unique features of the FSA, the larger picture appears to be one of continuity across the legal and organizational landscape of the last century. From DHS to immigration to economic policy and foreign affairs, time and again the ultimate impact of public law depends on who secures control of the nation's bureaucracy, and (in turn) on how organization is used to define the contested concept of the nation's security. What the story of the FSA shows - and that of DHS echoes $^{455}$-is how these dynamics are interrelated. On the one hand, major actors in controlling public law-including key lawmakers, the White House, and courts - assign exceedingly high importance to the question of who controls the national bureaucracy. In the short run, control of the organizations carrying out legal functions translates into control over the interpretation and implementation of law. Organizational control of the bureaucracy shapes the architecture of public law in the longer run, because bureaucracies shape the legislative agenda, impact public perceptions, and develop degrees of autonomy or particular cultures affecting how legal powers are actually used. On the other hand, political actors expend considerable effort to define what security means, whether the question is the relationship between health and national defense, the role of natural disaster response in national strategy, or the precise significance of immigration policy to some conception of security. Often, such efforts pivot on securing control of the bureaucratic entities carrying out government functions and therefore capable, at the margin, of affecting public perceptions of government activity.

These dynamics arise in part because organizational changes appear capable of exerting a more powerful influence than previously realized on the law's evolution. In the case of the FSA, reorganization helped a cluster of health research, human services, and education agencies envision a common purpose and expand their bureaucratic

453 See Ewing, More Security for You, Am Mag at 1 (cited in note 160).

454 See, for example, Stephen Flynn, The Edge of Disaster: Rebuilding a Resilient Nation 170 (Random House 2007) (asserting that terrorism is only one of a "growing list of potentially catastrophic events that threatens the public" and arguing that the Bush administration did not sufficiently prepare for these other risks).

455 See Cohen, Cuéllar, and Weingast, 59 Stan L Rev at 739 (cited in note 26) (discussing the relationship between bureaucratic control and the definition of "security" in the DHS context). 
mandate during a politically risky time. They set in motion the growth of much of the modern federal government, helping fragile administrative and regulatory bureaucracies develop coalitions of political supporters and distinct organizational cultures-qualities that would have been difficult to forge had these entities remained stuck as marginal bureaus in departments with discordant overarching missions (for example, the PHS in Treasury, or the Office of Education in Interior) or remained lone bureaus bereft of an organizational structure implying a larger project or purpose.

The organizational structure embodying the FSA further provided these bureaus with a mechanism for political and legal advocacy, facilitating relations with Congress, coordinating bureaus' activities, and allowing for the development of new legal interpretations and policy proposals. Nearly every major change in American regulatory policy that followed the New Deal during the twentieth century-from Social Security expansion and Medicare, to the original clean air regulatory framework, to the modern infrastructure for pharmaceutical, food, and consumer products regulation-initially involved the FSA or its successor agency. Had Roosevelt failed to create a bureaucratic mechanism for proposing, advocating, and implementing these policies, such initiatives would almost certainly have faced a less hospitable political environment. By the same token, opponents of national health insurance pointedly opposed the FSA's elevation to cabinet status while insisting that such a change would strengthen Truman's bureaucratic resources for pursuing the goal of broadening health coverage. ${ }^{456}$

As a complement to these changes in the hierarchical machinery of the federal bureaucracy, agency architecture helped reshape the public imagination about the concept of security. Specifically, the agency's legal architecture emphasized how education and public health research could promote war production and civil defense. It was a rhetorical dynamic emphasized at every turn by both the FSA's leadership and the White House. The reorganization also helped the White House nurture, protect, and control some of its most prized administrative and regulatory programs at a time when the administration's political capital was on the wane, critics were pointing to the panoply of disaggregated independent agencies as a reason to shrink government, and White House staff resources to monitor and control administrative develop-

456 Opponents seem to have feared two things: the public attention that such an elevation would have brought to the health issue at a time when Truman was eagerly seeking to turn it into a major subject of national debate; and the further bureaucratic resources (in terms of additional political appointees) Truman would gain, which in turn could facilitate efforts to use the agency's analytical and advocacy resources to promote the drive for national health insurance. See notes 157-167 and accompanying text. 
ments were almost nonexistent. These developments did not ensure that all subsequent legal and political battles on behalf of the FSA's subcomponents were won. On the other hand, the events surrounding the creation and evolution of the FSA left their mark in terms of the connection between defense and health in modern government bureaucracies and the relative centralization of regulatory power in just a few entities that indelibly shape American life.

That centralization process yields two final, broader implications for public law. First, because of the elevated stakes involved in organizing agencies, separation of powers disputes will continue to turn on how lawmakers and the White House split the power to structure (and restructure) the bureaucracy. Messy as the modern separation of powers doctrine has become, ${ }^{457}$ with its functional concerns over branch aggrandizement and its basic acknowledgement of shared power in a host of domains, finding an alternative may be exceedingly difficult. Crisp rules are elusive here, and neither history nor the basic logic of the relevant law support the unitary executive theories rejected in Humphrey's Executor. If accepted, such theories would run the risk of leaving the president with enough power to achieve through practical control of the bureaucracy anything that she could not achieve through direct, ostensibly legally binding instructions that contradicted statutory commands. In the end, structural control over hiring, firing, budgets, and regulatory power works as a substitute and a complement for formal legal power achieved through interpretations of traditional separation of powers doctrine. It is precisely this story that the Roosevelt administration's reaction to Humphrey's Executor ultimately tells.

Second, the fight over security's multiple strands sheds light on lingering questions about the role of incrementalism in achieving legal and social change. Conceptual questions about the scope of security ran together with practical choices about how-and how rapidly - to alter existing legal arrangements. The answers to these questions at the FSA's origin emphasize the unique and sometimes discontinuous impact of political strategy. An incremental approach to building a "Department of Public Welfare" was not what Roosevelt first envisioned when he sought to secure greater control of the nation's bureaucracy. Reluctantly, Roosevelt was forced to consider more carefully the nature of congressional opposition. But then, the mechanics through which the Social Security program had itself been turned into legislation a half-decade earlier were themselves an excruciating exercise in compromise. Mak-

457 See, for example, M. Elizabeth Magill, Beyond Powers and Branches in Separation of Powers Law, $150 \mathrm{U}$ Pa L Rev 603, 612 (2001) (arguing that separation of powers doctrine erroneously assumes that powers can be neatly separated when, in fact, there is no commonly accepted way to distinguish government functions in contested cases). 
ing deals with House and Senate tax-writing committees, the administration had simultaneously limited the program's scope but also expanded its base of support among moderate and even conservative lawmakers on Capitol Hill. Much the same was true of the security-related reorganization that engendered the FSA. Had the Roosevelt administration succeeded in obtaining the sweeping reorganization powers it sought under the original bill, the president would almost certainly have proposed more-and more far-reaching-reorganization plans.

There is something distinctive about Roosevelt's moves and the sprawling agency it produced. Although the concept of security may be inherently capable of encompassing a broad range of policies associated with social well-being and national strength, it was the Roosevelt administration's determined reaction-even in the face of congressional defeat - that transformed that broad concept into a viable bureaucratic structure. Frustrated though he was at the time, the legislative backlash may have coaxed Roosevelt in a direction that minimized opposition to the new agency at the time when it was most vulnerable. By settling for limited reorganization powers, the Roosevelt administration likely placed the FSA's bureaus in a more viable longterm position, one that combined incremental growth with a politically valuable blend of national security and domestic policy rationales. With the evolution of the FSA thus set in motion, Roosevelt demonstrated yet again the irony of how politics, to be commanded, must be obeyed. 


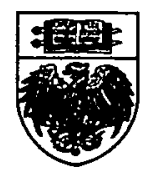

